\title{
In het verkeerde bed : het zorgtraject van een cohort CVA-patienten na ziekenhuisopname
}

Citation for published version (APA):

Hermans, E. (2000). In het verkeerde bed : het zorgtraject van een cohort CVA-patienten na ziekenhuisopname. [Doctoral Thesis, Maastricht University]. Datawyse / Universitaire Pers Maastricht. https://doi.org/10.26481/dis.20000519eh

Document status and date:

Published: 01/01/2000

DOI:

10.26481/dis.20000519eh

Document Version:

Publisher's PDF, also known as Version of record

\section{Please check the document version of this publication:}

- A submitted manuscript is the version of the article upon submission and before peer-review. There can be important differences between the submitted version and the official published version of record. People interested in the research are advised to contact the author for the final version of the publication, or visit the DOI to the publisher's website.

- The final author version and the galley proof are versions of the publication after peer review.

- The final published version features the final layout of the paper including the volume, issue and page numbers.

Link to publication

\footnotetext{
General rights rights.

- You may freely distribute the URL identifying the publication in the public portal. please follow below link for the End User Agreement:

www.umlib.nl/taverne-license

Take down policy

If you believe that this document breaches copyright please contact us at:

repository@maastrichtuniversity.nl

providing details and we will investigate your claim.
}

Copyright and moral rights for the publications made accessible in the public portal are retained by the authors and/or other copyright owners and it is a condition of accessing publications that users recognise and abide by the legal requirements associated with these

- Users may download and print one copy of any publication from the public portal for the purpose of private study or research.

- You may not further distribute the material or use it for any profit-making activity or commercial gain

If the publication is distributed under the terms of Article $25 \mathrm{fa}$ of the Dutch Copyright Act, indicated by the "Taverne" license above, 


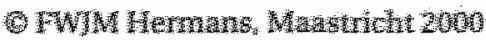

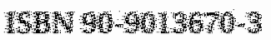

Womgenump en

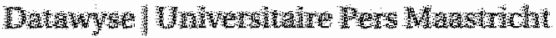




\title{
IN HET VERKEERDE BED
}

Het zorgtraject van een cohort CVA-patiënten na ziekenhuisopname

\author{
PROEFSCHRIFT \\ ter verkrijging van de graad van doctor \\ aan de Universiteit Maastricht, \\ op gezag van de Rector Magnificus, \\ Prof. dr. A.C. Nieuwenhuijzen Kruseman \\ volgens het besluit van het College van Decanen, \\ in het openbaar te verdedigen op \\ vrijdag 19 mei 2000 om 14.00 uur \\ door \\ ERIC HERMANS
}


PROMOTOR

Prof. dr. H. Philipsen

CO-PROMOTOR

Dr. J.P.M. Diederiks

BEOORDELINGSCOMMISSIE

Prof. mr. F.C.B. van Wijmen (voorzitter)

Prof. dr. A.C. van den Hout (Katholieke Universiteit Nijmegen)

Dr. M.C.M. Senten (Nederlandse Hartstichting Den Haag)

Prof. dr. C. Spreeuwenberg

Het verschijnen van dit proefschrift werd mede mogelijk gemaakt door de steun wan de Nederlandse Hartstichting

en van de Hersenstichting Nederland.

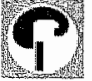




\section{Inhoudsopgave}

HOOFDSTUK 1

Introductie

HOOFDSTUK 2

Patiëntkenmerken met voorspellende betekenis voor verkeerdebedproblematiek op de neurologische afdeling van een algemeen ziekenhuis

HOOFDSTUK 3

Home care-a realistic alternative for bed-blocking stroke victims in acute hospital wards?

HOOFDSTUK 4

CVA-patiënten in het verkeerde bed

HOOFDSTUK 5

Multidisciplinaire beoordeling van mogelijke vervolgzorg voor CVA-patiënten in het verkeerde bed

HOOFDSTUK 6

Lange termijn uitkomsten en substitutiewinst onder CVA-patiënten in het verkeerde bed

HOOFDSTUK 7

Use of care by home-dwelling stroke patients during 3 years

following hospital discharge

HOOFDSTUK 8

Beschouwing

HOOFDSTUK 9

Samenvatting 
HOOFDSTUK 10

Summary

HOOFDSTUK 11

Dankwoord

Curriculum Vitae

BIJLAGE

Project Integraal Regionaal 


\section{Introductie}

\section{ACHTERGROND EN AANLEIDING}

In 1989 introduceerde Het Ministerie van Welzijn, Volksgezondheid en Culturur het beleidsprogramma Zorgvernieuwingsprojecten Thuiszorg (Ministerie van WVC 1989). Het algemene doel van het beleidsprogramma was om door verbetering van het thuiszorgaanbod een alternatief te bieden voor verblijf in een intramurale instelling. De uitkomst van een dergelijk streven heet substitutie: de vervanging van tweedelijnszorg door eerstelijnszorg of thuiszorg. De kwaliteit van de zorg in het ziekenhuis staat hierbij niet ter discussie, maar thuiszorg wordt geacht zowel meer te voldoen aan het principe van zorg-op-maat, als efficiënt te zijn in financieel opzicht. In ieder geval treedt minder beslag op ziekenhuisbedden op. Een van de projecten uit het beleidsprogramma was Integraal Regionaal dat van 1990 tot en met 1992 werd uitgevoerd in de Westelijke Mijnstreek, het verzorgingsgebied van het Maaslandziekenhuis Sittard-Geleen. Dit project richtte zich vooral op de problematiek van onnodig lang verblijf in het ziekenhuis, bekend als verkeerde-bedproblematiek. Een typisch voorbeeld hiervan is de oudere patiënt met complexe problematiek die medisch-specialistisch uitbehandeld is, maar niet uit het ziekenhuis ontslagen kan worden. In Integraal Regionaal is gekozen voor actie-onderzoek onder CVA-patiënten, een diagnosegroep waaronder verkeerde-bedproblematiek veel voorkomt. Na een bevredigende pilot-fase is in het eigenlijke onderzoek door een panel van experts nagegaan of verkeerde-bedpatiënten met CVA, die gedurende het jaar 1992 in het ziekenhuis werden opgenomen, terug naar huis of naar een verzorgingshuis ontslagen zouden kunnen worden. In het project ging het er vooral om de haalbaarheid vast te stellen van deze procedures, alsmede het resultaat ervan. In paragraaf 3 van dit hoofdstuk wordt Integraal Regionaal in hoofdlijnen beschreven.

$\mathrm{Na}$ beëindiging van het project is besloten om een aantal wetenschappelijke publicaties te schrijven waarin verslag wordt gedaan van de uitkomsten. Daarbij lag het accent op drie vragen: 
- de vraag naar de omvang van verkeerde-bedproblematiek onder CVApatiënten,

- de vraag naar de determinanten van verkeerde-bedproblematiek bij CVApatiënten, en

- de vraag naar de substitueerbaarheid van verkeerde-bedpatiënten met CVA volgens het oordeel van een panel van zorgverleners.

Deze vragen bleken onderzoeksmatig adequaat beantwoord te kunnen worden. Op grond van deze constatering is voortgezet onderzoek uitgevoerd ten aanzien van een tweetal problemen.

Het eerste probleem betrof de reproduceerbaarheid en geldigheid van het paneloordeel. Indien men de uitkomsten van Integraal Regionaal zou willen generaliseren, is het noodzakelijk om vast te stellen of dit oordeel reproduceerbaar en geldig is. Daarom werd besloten om de casus die waren beoordeeld door experts uit de Westelijke Mijnstreek systematisch voor te leggen aan categorieën experts van buiten de regio. Indien hun meningen zowel onderling overeen zouden stemmen, als overeen zouden stemmen met het oorspronkelijke paneloordeel, is er sprake van een resultaat dat niet particularistisch of idiosyncratisch van aard, en derhalve de moeite waard is. Aldus ontstond een vierde onderzoeksvraag:

- de vraag naar de reproduceerbaarheid van het paneloordeel indien geabstraheerd wordt van de regionale situatie.

Een tweede probleem waar het vervolgonderzoek zich op richtte betrof de korte duur van het onderzoek in de zorgvernieuwingsprojecten uit het beleidsprogramma van WVC. Doordat de populatie van Integraal Regionaal goed beschreven was, was het mogelijk om drie jaar na afsluiting van het project een follow-up te laten plaatsvinden naar uitkomsten op lange termijn als overleving en verblijfplaats. Aldus ontstonden een vijfde, zesde en zevende onderzoeksvraag:

- de vraag naar de loopbaan, en de uitkomsten op lange termijn en de determinanten hiervan onder verkeerde-bedpatiënten met CVA,

- de vraag naar de samenhang tussen het paneloordeel en de uitkomsten op lange termijn,

- de vraag of aan de hand van de lange termijn uitkomsten een indicatie verkregen kan worden van de omvang van de substitutiewinst die onder deze groep realiseerbaar is.

Tenslotte rees nog een derde probleem. Niet alle patiënten uit de onderzoekscohort die in het ziekenhuis werden opgenomen wegens CVA, kwamen 
in het verkeerde bed. Er waren patiënten die wel tijdig konden terugkeren naar hun eigen huis. Het is interessant om vast te stellen hoe groot de zorgbehoefte en het gebruik van voorzieningen is onder deze uit het oog van de institutionele zorg geraakte groep. Dat leidde tot de achtste onderzoeksvraag:

- de vraag naar de gesteldheid van CVA-patiënten die niet in het verkeerde bed hadden gelegen drie jaar na ziekenhuisontslag.

Om de opzet en uitvoering van het vervolgonderzoek te kunnen beoordelen dient de vraag beantwoord te worden hoe wetenschappelijk verantwoord het was om op de ingeslagen weg van Integraal Regionaal voort te gaan. Er is daarvoor een aantal tegenargumenten. Allereerst was Integraal Regionaal niet opgezet vanuit een wetenschappelijke vraagstelling. Daarmee was definitief de mogelijkheid verloren om later nog variabelen toe te voegen, meetmomenten aan te passen, of de populatie te wijzigen. Verder was het project een één-praktijjk-onderzoek. Hoe zorgvuldig de procedures ook waren overwogen, uiteindelijk beslisten neurologen uit één en dezelfde praktijk over de diagnose, het beëindigen van de medisch-specialistische behandeling en daarmee het aanwijzen van verkeerde-beddagen. Dat toch besloten is om het onderzoek in wetenschappelijke zin verder uit te bouwen berust op de volgende overwegingen. In de eerste plaats is het aantal beschikbare variabelen en hun kwaliteit redelijk tot goed, in elk geval met betrekking tot de hoofdvraag omtrent substitutie. Daarnaast beschikt de regio Westelijke Mijnstreek over slechts één ziekenhuis, waarvan het verzorgingsgebied nagenoeg samenvalt met de regiogrenzen. Voor opname wegens CVA zal men derhalve niet makkelijk buiten de eigen regio terechtkomen. Het onderzoek beslaat hierdoor, en door het feit dat het onderzoek een heel kalenderjaar besloeg een heldere en omvangrijke populatie. Deze populatie is bovendien niet zodanig uitzonderlijk dat voorzichtigheid bij de interpretatie van de resultaten op zijn plaats is. De aanwijzing door WVC als regio voor een zorgvernieuwingsproject wijst ook in deze richting. Een laatste argument waarom het onderzoekverder is uitgebouwd heeft te maken met de aard van thuiszorg voor patiënten met complexe zorgvragen. Dit type thuiszorg is sterk afhankelijk van gemeenschappelijk overleg en gemeenschappelijke oordeelsvorming van professionals uit diverse disciplines en zorgverlenende instanties. Hierover is weinig bekend, en onderzoek dat hieraan bijdraagt is derhalve de moeite waard. Mutatis mutandis geldt eenzelfde argument voor longitudinaal onderzoek: elke kans om voor een welomschreven populatie effecten op langere termijn te meten verdient aanbeveling. 
In dit hoofdstuk zal in paragraaf 2 allereerst worden ingegaan op de aard, ornvang en ziektelast van CVA, en op hoofdlijnen van het zorgtraject van CVA-patiënten. In paragraaf 3 wordt vervolgens nader ingegaan op het project Integraal Regionaal, In paragraaf 4 worden de resultaten van een literatuuronderzoek naar verkeerde-bedproblematiek beschreven. In paragraaf 5 worden tenslotte de operationele onderzoeksvragen weergegeven.

\section{CVA: AARD, OMVANG, ZIEKTELAST EN ZORGTRAJECT}

\subsection{AARD EN OMVANG}

De definitie van CVA luidt: "plotseling ontstane klinische verschijnselen van een focale stoornis van de hersenfunctie met een duur van meer dan 24 uur of eindigend met de dood, waarvoor geen andere oorzaak aanwezig lijkt dan een vasculaire stoornis" (WHO 1989). Deze definitie omvat Reversible Ischaemic Neurological Deficit (RIND), maar sluit Transient Ischaemic Attack (TIA) uit. RIND en TIA zijn beide achteraf-diagnosen, en hebben gemeen dat er sprake is van voorbijgaande neurologische uitvalsverschijnselen. Van TIA wordt gesproken indien de uitvalsverschijnselen binnen 24 uur verdwenen zijn; bij RIND is dit binnen een week het geval. Hoewel in de volksmond gesproken wordt van "hersenbloeding" zijn meer dan $80 \%$ van de CVA's infarcten en circa $15 \%$ bloedingen. De overige $5 \%$ zijn een verzameling van zeldzame en moeilijk classificeerbare vormen (Nederlandse Hartstichting 1996). De mortaliteit in de acute fase is 20 tot $25 \%$. Hoge leeftijd, bewustzijnsdaling, ernstige neurologische uitvalsverschijnselen en (vooral cardiale) comorbiditeit verhogen de kans op overlijden. Een effectieve therapie voor CVA is niet beschikbaar. Onderzoek naar de effecten van therapie met thrombolytica en neuroprotectieve middelen in de acute fase van herseninfarcten wordt aanbevolen. Patiënten die een CVA overleven hebben een verkorte levensverwachting, vooral vanwege cardiale afwijkingen. In westerse landen staan CVA's na hartinfarcten en kanker op de derde plaats van meest voorkomende doodsoorzaken. De jaarlijkse incidentie van CVA, gemeten in het enige bevolkingsonderzoek dat in Nederland tot nu toe heeft plaatsgevonden bedraagt 174 per 100.000 inwoners (Herman et al 1981). Voor mannen is de incidentie hoger dan voor vrouwen. Over de prevalentie is nog weinig bekend, maar uitgaande van de genoemde incidentie en van een gemiddelde ziekteduur van 4 jaar zou deze 648 per 100.000 kunnen bedragen (CBO 1991). Hoewel CVA's op elke leeftijd voorkomen, stijgt het risico sterk met het 
klimmen der jaren, en kan op grond van de verwachte veranderingen in de leeftijdsopbouw wereldwijd een dramatische stijging tegemoet worden gezien (Chambers et al 1987, Shuaib \& Boyle 1994, Bonita et al 1994, Sacco 1995). Ook in Nederland is een stijging van het aantal eerste CVA-gevallen te verwachten (NWO 1995, Lodder \& Bouter 1992). Lodder en Bouter (1992) verwachten dat het aantal eerste CVA-gevallen tot 2020 met $40 \%$ tot $60 \%$ zal stijgen vergeleken met 1990 .

\subsection{ZIEKTELAST}

De gevolgen van een CVA zijn zeer invaliderend, maar incidentie- en prevalentiecijfers over aard en omvang van de stoornissen, beperkingen, handicaps en kwaliteit van leven ontbreken (Meyboom-de Jong \& Buis (eindred.) 1995). CVA is zowel in lichamelijk als in psychosociaal opzicht naar verhouding de meest belastende aandoening (van den Bos 1989, Meyboom-de Jong 1989). Na een CVA stijgt het zorggebruik dan ook substantieel (de Haan et al 1994). CVA's maken in Nederland $2 \%$ van het totaal aantal ziekenhuisopnamen en $4 \%$ van het totaal aantal verpleegdagen uit. Ongeveer de helft van alle patiënten blijft gehandicapt (Meyboom-de Jong \& Buis (eindred.) 1995). Stoornissen betreffen vooral halfzijdig krachtsverlies (hemiparese) of -verlamming (hemiplegie). Veel voorkomend zijn ookstem- spraak- en taalstoornissen, intellectuele en andere psychische stoornissen, huid-, sensibiliteits-, visus-, geheugen- en zintuigstoornissen, stoornissen met slikken en kauwen, pijn en incontinentie. Verder is er sprake van depressie, verstoorde controle en verstoorde sociale perceptie. Stoornissen komen in alle mogelijke combinaties voor, en hebben vaak zeer ernstige gevolgen voor patiënten met betrekking tot de persoonlijke verzorging, huishoudelijke activiteiten, arbeid en recreatie. De gemiddelde totale medische kosten na een CVA bedragen $\mathrm{f}$. 71.000 ,- voor mannen en f. 83.000,- voor vrouwen. Het verschil wordt veroorzaakt door het feit dat mannen vaker terug naar huis gaan en vrouwen vaker in een verpleeghuis worden opgenomen. Door de betere prognose van patiënten met een infarct zijn de kosten voor hen hoger dan voor patiënten met bloedingen. De verwachte levenslange medische kosten voor alle patiënten met een eerste CVA bedragen bijna 2 miljard gulden (Bergman et al 1997). 


\subsection{ZORGTRAJECT}

Van de patienten die een CVA krijgen wordt $97 \%$ door de huisarts gezien, en ongeveer twee-derde deel wordt in een ziekenhuis opgenomen. Vooral de emst van het ziektebeeld, de functiebeperkingen en de leeftijd van de patiënt zijn bepalend voor het besluit tot opname (Schuling 1993). Bij gelijke ernst zijn het vooral de patiënten die jonger zijn dan 70 jaar die naar het ziekenhuis verwezen worden. Patiënten die thuisblijven zijn vooral hoogbejaarden, en. daarnaast mensen die thuis voldoende verzorgingsmogelijkheden hebben (Schuling 1993, van der Meer \& Smith 1990). Ziekenhuisopname vindt in Nederland wooral plaats vanwege nadere diagnostiek. Deze omvat in ieder geval een CT-scan om te kunnen differentiëren tussen infarct en bloeding. Opname vindt bijna altijd plaats op de neurologische afdeling. CVA-patiënten vormen op deze afdeling dan ook een omvangrijke en zorgintensieve categorie. De meeste patiënten gaan na verblijf in het ziekenhuis binnen enkele weken weer naar huis (van der Meer \& Smith 1990). Voor ruim $10 \%$ is permanente opname, meestal in een verpleeghuis noodzakelijk (Meyboom-De Jong \& Buis (eindred.) 1995). Ook is duidelijk dat CVA-patiënten vaak veel langer in het ziekenhuis verblijven dan nodig of wenselijk is Vosbeek 1990). Uit recent Nederlands onderzoek bleek een gemiddelde verblijfsduur van 28 dagen (van Straten et al 1997), terwijl neurologen vinden dat 10 dagen meestal voldoende is (Brunet de Rochebrune \& van Dijk, 1997). Deze zogenaamde verkeerde-bedproblematiek ontstaat onder meer als gevolg van capaciteitstekorten elders, voornamelijk in verpleeghuizen. Een ander knelpunt betreft de overdracht van zorg vanuit het ziekenhuis naar de thuiszorg, die vaak onvoldoende is voorbereid. Verder sluit de zorg in de thuissituatie slecht aan op die in het ziekenhuis, waardoor patiënten na thuiskomst regelmatig in een 'zwart gat' vallen (Sickinger 1992). Tenslotte is de zorgbehoefte van patiẹnten en partners nog slecht in beeld gebracht, waardoor partners overbelast raken (Schure 1995).

De CVA-zorg in Nederland is momenteel sterk in beweging. Met name wint het besef terrein dat neurologische screening in alle gevallen noodzakelijk is, en dat met een gerichte, intensieve aanpak door een gespecialiseerd, multidisciplinair team op een speciale ziekenhuisafdeling (stroke-unit) direct na een CVA in veel gevallen substantiële functionele winst te behalen is (Dennis \& Langhorne 1994). Hierdoor, en door de verwachte stijging van het aantal eerste CVA-gevallen neemt de belangstelling voor het zorgtraject van CVA-patiënten sterk toe. 
Nieuwe zorginitiatieven voor CVA-patiënten richten zich vooral op samenwerking tussen disciplines, afstemming van het zorgaanbod, en daarmee op het bevorderen van de continuilteit van zorg (Meyboom \& Buis (eindred.) 1995). Er wordt geëxperimenteerd met fenomenen als transfer-verpleegkundige, stroke nurse, gedifferentieerde wijkverpleegkundige met aandachtsveld CVA, en thuiszorg in combinatie met korte ziekenhuisopname. Het streven naar stroomlijning van het zorgtraject van CVA-patiënten neemt de vorm aan van transmurale stroke services (Dennis 1992, Limburg 1997, Stolker et al 1997). Stroke service kan worden omschreven als een regionaal netwerk van voorzieningen met een gezamenlijke verantwoordelijkheid voor een integrale, samenhangende, geprotocolleerde en deskundige zorg aan CVA-patiënten en hun omgeving. Afspraken tussen zorgaanbieders moeten de doorstroming van cliënten verbeteren, en ervoor zorgen dat deze de juiste zorg op de juiste plaats en de juiste tijd krijgen.

Volgens de World Health Organization moeten in het jaar 2005 in alle europese landen CVA-patiënten binnen 6 uur worden opgenomen op een stroke-unit (Pan European Consensus Meeting on stroke Management, 1996). Om goed te kunnen functioneren is het van belang dat de stroke unit is ingebed in een stroke service (Franke, 1997, Limburg 1997). Opname op de stroke unit moet kortdurend zijn; er moet snelle diagnostiek plaatsvinden, en zo nodig eerste revalidatie gegeven worden. Vervolgens moet de patiënt zo snel mogelijk overgeplaatst worden naar de meest geschikte plek voor revalidatie en nazorg. Dit moet, net als de begeleiding van de naaste omgeving van de patiënt in de stroke service worden geregeld. Door de stroke service moeten overgangen in de zorg veel meer dan thans het geval is, vloeiend en zonder wachttijden verlopen. In dit verband is van belang dat er door de korte opname op de stroke unit een ware vloedgolf op gang komt aan snel ontslagen patiënten vanuit het ziekenhuis in de richting van andlere participanten aan de stroke service. Franke (1997) heeft uiteengezet dat het, om de ontwikkeling van goed functionerende stroke services niet te frustreren, noodzakelijk is om maatregelen te treffen in de capaciteitssfeer, en dan vooral buiten het ziekenhuis.

Ondanks alle zorgvernieuwende initiatieven blijft de verkeerde-bedproblematiek echter nog steeds een belangwekkend en omvangrijk probleem in de zorg (NRV 1995). 


\section{HET PROJECT INTEGRAAL REGIONAAL}

Het project Integraal Regionaal heeft een belangrijk deel van het materiaal voor dit proefschrift opgeleverd. Het project vond plaats onder verantwoordelikheid van het Algemeen Samenwerkingsverband Gezondheidszorg en Maatschappelijke Dienstverlening Westelijke Mijnstreek.

Deelnemers waren: het Maaslandziekenhuis, de medische staf van dit ziekenhuis, de verpleeghuizen en de verzorgingshuizen in de regio, twee kruisverenigingen (wijkverpleging), twee instellingen voor gezinsverzorging en de regionale huisartsenvereniging. De twee kruisverenigingen en de twee instellingen voor gezinsverzorging zijn intussen overigens gefuseerd in de Stichting Thuiszorg Westelijke Mijnstreek. Het project beoogde te onderzoeken of, en zo ja in welke mate en voor welke patiënten, thuiszorg of zorg in een verzorgingshuis -eventueel met enige nader te onderzoeken toevoegingen aan het reguliere zorgaanbod-een alternatief zou kunnen bieden voor de verkeerde-bedproblematiek onder CVA-patiënten in het ziekenhuis. Thuiszorg werd opgevat als georganiseerde gezondheidszorg en dienstverlening in de eigen woon- en leefsituatie van de hulpvrager (Ministerie van WVC, 1989). In de praktijk betekende dit dat het ging om alle zorg die gegeven wordt in het huis van de patiënt of die van daaruit bereikbaar is.

Het project kende een pilot-fase en een hoofdfase. In de pilot-fase vond een kleinschalig feasibility-onderzoek plaats. Zeven CVA-patiënten die in het verkeerde bed lagen werden daadwerkelijk naar huis geplaatst om te onderzoeken of voor deze patiëntencategorie door middel van thuiszorg een potentieel alternatief geboden kon worden voor een langer verblijf in het verkeerde bed. Alle zeven patiënten hadden een verpleeghuisindicatie. De aan het project deelnemende zorgaanbieders hadden zich vooraf verplicht om aan dit beperkt aantal patiènten daadwerkelijk $k_{p}$ en met gesloten beurzen alle hulp te verlenen die zij nodig zouden hebben in de thuissituatie. Vastgelegd werd welke toevoegingen aan het reguliere thuiszorgaanbod noodzakelijk waren om de thuiszorg voor deze zeven patiẻnten te bestendigen. De eerste patiënt ging naar huis in september 1990. Twee jaar na de start van het thuiszorgexperiment verbleven vijf van de zeven patiënten nog steeds in de thuissituatie. Eén patiënt was thuis overleden, en de zevende was, conform de planning bij ziekenhuisontslag intussen opgenomen in een verzorgingshuis. Deze laatste patiënt had de wachttijd voor opname in het verzorgingshuis thuis kunnen overbruggen; voor de andere zes patiënten was thuiszorg een duurzaam alternatief gebleken voor een verblijf in het verkeerde bed. 
Bovendien was voor in elk geval vijf van hen definitieve opname in een verpleeghuis met tenminste twee jaar uitgesteld.

Hoewel de zorgbehoefte groot was, was de voornaamste conclusie die aan het eind van deze fase door de stuurgroep van het project werd getrokken, dat het bieden van thuiszorg voor deze populatie zeker niet zonder perspectief was (Hermans 1992). De vraag naar de kosteneffectiviteit van deze vorm van thuiszorg is in het project buiten beschouwing gebleven. Zeker is echter dat met het reguliere thuiszorgaanbod de zorgbehoefte van deze patiënten niet gedekt kon worden. Alle patiënten hadden gedurende hun volledige verblijf thuis gedurende drie dagen per week gebruik gemaakt van dagbehandeling in een verpleeghuis. Verder hadden zij gemiddeld achttien uur per week hulp van de gezinsverzorging gehad. De huisarts en de wijkverpleging hadden aan de patiënten niet meer dan de standaard hoeveelheid hulp en zorg geboden. Het bleek dat de thuiszorg in het algemeen goed te coördineren was (Hermans 1992). Ondanks deze conclusies is aan het eind van deze fase van het project de directe overdracht van verkeerde-bedpatiënten naar de thuiszorg gestopt omdat participanten het niet eens konden worden over de wijze van financiering van thuiszorg ten behoeve van deze doelgroep ${ }^{1}$

Participanten besloten daarom om in de hoofdfase van het project Integraal Regionaal op theoretische basis te onderzoeken voor hoeveel en voor welke verkeerde-bedpatiënten met een CVA deze vorm van thuiszorg haalbaar zou kunnen zijn. Bovendien werd in deze projectfase naast thuiszorg ook zorg in een verzorgingshuis als mogelijk allternatief voor het verkeerde bed onderzocht. De gedachtegang was dat de zorgbehoefte van een aantal patiënten wellicht té intensief en/of complex was om in aanmerking te kunnen komen voor thuiszorg, maar dat aan deze zorgbehoefte wel tegemoet kon worden gekomen in een verzorgingshuis.

\section{TWEE CASE HISTORIES}

Om te illustreren hoe verkeerde-bedproblematiek in de alledaagse werkelijkheid ontstaat, wat het betekent, en hoe substitutie vorm kan kri.jgen, worden in het onderstaande twee case histories beschreven. Beide cases zijn ontleend aan het project Integraal Regionaal.

1 Voor een gedetailleerde beschrijving van de pillot-fase van het project wordt verwezen naar de bijlage. 


\section{DE HEER EN MEVROUW V.}

Mevrouw $W$. is 58 jaar ats zij tijdens een warme zomemacht een beroerte krijgt. $2 \mathrm{ij}$ is naar het toilet geweest als haar man haar op de badkamenloer hoort vallen. Hij haast zich zijn bed unt, en constateert dat zij gedeeltelijk verlamd is. Toch slaagt hij er in om haar terug in bed te krijgen. De huisarts is onbereikbaar en meneer $\mathrm{V}$. belt de ants die de dienst waar neemt. Deze komt meteen, maar zegt nadat hij mevrouw heeft onderzocht dat hij de volgende dag de eigen huisarts zal waarschuwen. Tegen het eind van de nacht komt hij op aandringen van meneer $V$. nog een keer terug, en acht hij het toch raadzamer om mevrouw naar het ziekenhuis te laten brengen. Hier werblijft zij 2,5 maand met een parese wan het linkerbeen en een spastische parese van de linkerarm. Tevens heeft zil lichte geheugen- en spraakstoormissen.

Begin september krijgt meneer $V$. een brief van de ziektekostenverzekeraar dat zijn vrouw in het verkeerde bed ligt, en dat zij eigenlijk naar een verpleeghuis zou moeten. 0p dat moment is in de regio net het project Integraal Regionaal van start gegaan. Dit project onderzoekt de mogelijkheid on CVA-patienten die in het verkeerde bed liggen thuis te verplegen en verzorgen. Mevrouw $V$. wordt door de behandelend neuroloog als een mogelijke kandidat voor dit project voorgedragen. Meneer en mevrouw $V$. zouden dit heel graag willen, maar zorgwerleners van de thuiszorg hebben zo hun twijfels. Zij beschrijwen meneer $V$. als een moeilijke en ruwe man, en betwiffelem of hij de belasting van de thuiszorg aan kan, en of er met hem afspraken te maken zijn. Op hulp van de kinderen hoeft niet gerekend te warden. Tenslotte wordt mede op aandringen wan de huisarts -die de thuiszorg zal coördineren-bestoten om het erop te wagen. Zo wordt mevrouw $V$. de eerste patient die in het project naar huis gaat. De hulpverlening wordt gestart met 2 bezoeken per dag door de wijkverpleging, 3 halve dagen per week gezinsverzorging en 3 dagen per week dagbehandeling in het somatisch verpleeghuis. Behalwe meneer $V$. is ook cen bevriende buturtbewoonster ingeschakeld in de mantelzong. Ruim 1,5 jaar loopt deze zorg in grote lijnen door. Meneer $W$. laat zich in die periode kennen als een zorgzame man, waarmee in tegenstelling tot de verwachting goed is samen te werkem. Hij besteedt honderden uren aan oefeningen ten behoeve van de revalidatie van zijn vrouw. Zelfs zijn grootste hobby, het schieten in de schutterij van zijn geboortedorp theeft hij hiervoor opgegeven.

Na 2 jaar gaat mevrouw $V$. plotseling vrij sterk achteruit. Zij wermagert zienderogen, en wordt angstig en moeilijk hanteerbaar; zij hangt om de nek van de verzorgende. Ondanks dat er reeds een paar kortdurende logeeropnames in het verpleeghuis hebben plaatsge vonden wil het echtpaar ook nu niets wan definitieve opname weten. "Ik heb hele goede en fijne jaren met haar samen gehad, dan laat ik haar nu toch zeker niet in de steek" zegt meneer $V$. De professionele thuiszorgers ondersteunen hem in deze opvatting en zetten de zarg voort totdat mevrouw $V$. in janulari 1993 in haar eigen huis overlijdt. 


\section{DE HEER EN MEVROUW' H.}

Het is een mooie zaterdagochtend in april. Meneer H. (66 jaar) is zoals gewoonlijk al heel vroeg opgestaan. Hij woont samen met zijn vrouw in een dorp vlakbij Sittard. Hij heeft de huisdieren en konijnen at verzorgd als hij zich afvraagt waar zijn vrouw (61) blifft. Als hij naar boven gaat om poolshoogte te nemen, ziet hij haar 'raar" in bed liggen. Zij spreekt en beweegt moeilijk. Hij waarschuwt meteen de huisarts. Deze wermoedt een beroerte en laat mevrouw naar het ziekenhuis vervoeren. Daar wordt het vermoeden bevestigd, en begint een langdurige opnameperiode; eerst enkele maanden ziekenhuis en daarna een half jaar verpleeghuis. Mevrouw heeft een linkszijdige hemiparese en gaat tamelijk langzaam vooruit. Het feit dat zij erg somber is over haar toekomst. vormt een belangrijke rem op haar vooruitgang.

Na 8 maanden wordt na overleg met alle betrokken hulpwerleners en het echtpaar $H$. besloten om te proberen of het mogelijk is mevrouw $H$. verder thuis te verzorgen in het kader van het project Integraal Regionaal. Meneer $\mathrm{H}$, is een krachtige en realistische man; hij is heel actief en heeft veel hobby's en bezigheden. De hulpverleners zullen erwoor waken dat deze man door de thuiszorg voor zijn vrouw niet overbelast raakt. Het echtpaar krijgt vier halve dagen per week hulp van de gezinsverzorging en elke werkdag een bezoek van de wijkverpleging. Verder gaat mevrouw drie dagen per week woor dagbehandeling naar het verpleeghuis.

Meneer $H$. laat in die tijd een ingrijpende verbouwing in het huis realiseren, waardoor een optimale verzarging van mevrouw mogelijk wordt. Het pessimisme van mevrouw wordt echter niet minder, en op de dagen dat zij thuis is wraagt zij erg veel aandacht van haar man. Voor hem zijn de dagen dat zijn vrouw naar de dagbehandeling gaat dan ook erg belangrijk. "Zonder die dagbehandeling hield ik het niet wol" zegt hij. "Ik kan dan even stoom afblazen, en mijn eigen bezigheden ontplooien". Een gelukkige omstandigheid is dat mevrouw het prettig vindt op de dagtherapie.

Vier jaar na de start wan de thuiszorg blijkt dat met handhaving van het bovenbeschreven zorgschema een stabiele situatie is ontstan. Weliswaar is even geprobeerd om de intensiteit van de dagbethandeling van mevrouw te werminderen. Maar omdat dit onmiddellijk leidde tot een terugval in haar mogetijkheden, is deze weer snel teruggebracht naar drie dagen per week. Het echtpaar prefereert deze situatie verre boven een definitieve opname van mevrouw in het verpleeghuis. 


\section{VERKEERDE-BEDPROBLEMATIEK: DEFINITIE,} OMVANG EN RISICOFACTOREN

\subsection{DEFINITIE}

Noch in Nederland, noch daarbuiten is eenduidig gedefinieerd wat onder onjuist of oneigenlijk gebruik van ziekenhuisbedden verstaan moet worden. In de Nederlandse literatuur wordt ter verwijzing naar dit fenomeen weliswaar vrij algemeen de term verkeerd bed gebruikt, maar de inhoud van dit begrip loopt uiteen. Het Nederlands onderzoek naar de verkeerde-bedproblematiek is grotendeels gebaseerd op in het ziekenhuis verblijvende patiënten met een verpleeghutsindicatie. Er zijn echter ook onderzoeken die uitgaan wan een ruimere probleemdefinitie. Zo hanteren De Gouw en Van Waveren (1993) als definitie van verkeerde-bedproblematiek: "het voortgezet verblijf in een ziekenhuis van personen die geîndiceerd zijn voor opname in een andersoortige instelling of voor terugplaatsing naar de thuissituatie met professionele thuiszorg, mits dit voortgezet verblijf het gevolg is van een tekort aan plaatsingsmogelijkheden in die instelling of een tekort aan professionele thuiszorg". Het minst restrictief wordt het verkeerde-bedprobleem benaderd in een gezamenlijk advies van de Nationale Raad voor de Volksgezondheid en het College voor Ziekenhuisvoorzieningen (1995): "onder verkeerde-bedpatiënten dienen in de toekomst al die patiënten te worden verstaan die zonder medische indicatie noodgedwongen in een ziekenhuis verblijven, ongeacht hun ontslagbestemming".

De internationale literatuur kent een zeer groot aantal termen om te refereren aan het onjuist gebruik van ziekenhuisbedden: "prolonged stay" (Rosenfeld et al 1957, Sloane et al 1981, Maguire et al 1986, Posner \& Lin 1975, Herman et al 1984, Marchette \& Holloman 1986), "inappropriate utilization" (Logan et al 1972, Restuccia \& Holloway 1976, Rosser \& Chir 1976, Gertman \& Restuccia 1981, Siu et al 1986), "back up" (Shapiro et al 1980), "back up patients" (Markson et al 1983), "misplacement" (Donaldson 1983), "hospital bed misutilization" (Zimmer 1974), "social stay" (Glass \& Weiner 1976), "administrative days" (Gruenberg \& Willemain 1982), "unnecessary days" (Weissert \& Matthews 1988). Hazell (1965) gebruikte de term "bed-blocker" voor oudere patiënten die in een ziekenhuisbed verblijven, maar geen ziekenhuisbehandeling meer behoeven. Deze term lijkt de overhand te krijgen in het gebruik (Rubin \& Davies 1975, McArdle et al 1975, Murphy 1977, McAlpine 1979, Burley et al 1979, Seymour \& Pringle 1982, Coid \& Crome 1986, Lewis \& Purdie 1988). Hall \& Bytheway (1982) hebben er echter op 
gewezen dat de term "blocked bed", hoewel veel gebruikt, nog geen enkele inhoudelijke betekenis heeft. Zij definiëren een "blocked bed" als "een bed dat bezet wordt door een patiënt die geen medisch specialistische hulp meer behoeft waar ziekenhuisverblijf voor nodig is, maar die toch nog in het ziekenhuis verblijft in afwachting van plaatsing in een residentiële voorziening of van terugplaatsing naar de thuissituatie".

Uit de literatuurstudie blijkt dat zowel in de Nederlandstalige als in de Engelstalige literatuur de betekenis van verkeerde-bedproblematiek zich beweegt in een bepaalde bandbreedte tussen enerzijds oneigenlijk (inappropriate) en anderzijds onjuist gebruik van ziekenhuisbedden (misutilization). In het laatste geval lijkt het alsof de schuld van het probleem bij de patiënt wordt gelegd.

In onze studie hebben wij als definitie van verkeerd bed gekozen: een bed dat bezet wordt door een patiënt die geen medisch specialistische zorg meer behoeft waar ziekenhuisverblijf voor nodig is, maar die toch nog in het ziekenhuis verblijft in afwachting wan overplaatsing naar een residentièle voorziening of naar de thuissituatie. Criteria om te bepalen wanneer er sprake is van een verkeerd bed zijn niet beschikbaar, zodat het oordeel van de behandelend specialist in deze doorslaggevend was.

\subsection{OMVANG}

In Nederland is de totalle omvang van het verkeerde-bedprobleem niet goed bekend. Dit komt door het gebruik van uiteenlopende definities "verschillen in onderzoekspopulaties en maten om de omvang uit te drukken (verpleegdagen, bedden). Volgens Vosbeek (1990) komen de resultaten van enquêtres van de Vereniging Nederlandse Ziekenfondsen en van de Nationale Ziekenhuisraad uit 1987 omgerekend uit op 120.000 en 160.000 dagen per jaar. El Ghouat (1987) komt tot 240.000 dagen. Volgens het College voor Ziekenhuisvoorzieningen (1992) leidt de officiële registratie tot een onderschatting van de problematiek. De werkelijke problematiek zou minstens 480.000 verkeerde-beddagen omvatten.

\subsection{RISICOFACTOREN VOOR VERKEERDE-BEDPROBLEMATIEK}

CVA. In de literatuur komt allerwegen het belang van de CVA-diagnose voor verkeerde bedden naar voren (Rosenfeld et al 1957. Zimmer 1974, Zimmer et al 1985, McArdle et al 1975, Donaldson 1983, Meiners \& Coffey 1985, Maguire 
et al 1986, Marchette \& Holloman 1986, Coid \& Crome 1986, Fields et all 1986, Tellis-Nayak \& Tellis-Nayak 1986, Jones \& Golding 1987, Weissert \& Matthews 1988, Lewis \& Purdie 1988, Wijdeven 1989, De Gouw \& van Waveren 1993). Leeftijd Door een aantal auteurs wordt gewezen op het belang van de leeftijd van de patiént voor verkeerde-bedproblematiek (Coid \& Crome 1986, Donaldson 1983, El Ghouat 1987, Lewis \& Purdie 1988, Maguire et al 1986, Marchette \& Holloman 1986, Murphy 1977, Rosenfeld et al 1957, Wijdeven 1989). Birnen de groep CVA-patiënten werd geen verband gevonden tussen leeftijd en lengte van ziekenhuisverblijf (Herman et al (1984).

Geslacht. Sommige auteurs rapporteren het geslacht van de patiënt (vrouw-zijin) als risicofactor voor verkeerde-bedproblematiek (Rubin et al 1975, Sloane et all 1981, Seymour \& Pringle 1982, Donaldson 1983, Meiners \& Coffey 1.985, Tellis-Nayak \& Tellis-Nayak 1986, Jones \& Golding 1987). Het is niet onwaarschijnlijk dat de hogere gemiddelde leeftijd van vrouwen een rol speelt in de bevinding dat vrouwen significant vaker in het verkeerde bed liggen.

Woonsituatie. Maguire et al (1986) vonden geen relatie tussen "prolonged stay" en sociale omstandigheden; zij concluderen dan ook evenals Seymour \& Pringle (1982) dat verlengd ziekenhuisverblijf veroorzaakt wordt door medische, en niet door sociale redenen. Andere auteurs hebben wel uitdrukkelijk gewezen op het belang van sociale factoren. Murphy (1977) vond dat veel patiênten die slechts sociale zorg nodig hadden nog in het ziekenhuis verbleven, omdat het hun thuis ontbrak aan iemand die in deze behoefte kon voorzien. Rosenfeld et al (1957) wijzen op de ongeschiktheid van het huis van veel patiënten om thuis verzorgd te kunnen worden. Voorts komt de weigering van de familie om de zorg voor de patiënt in de thuissituatie op zich te nemen als een belangrijk element naar voren. Volgens Coid en Crome (1986) was in $49 \%$ van de gevallen een belangrijk sociaal probleem de reden van verkeerde-bedproblematiek en woonde $43 \%$ van deze patiênten alleen. Volgens McArdle et al (1975) woonde van de zeer langdurige "bed-blockers" zelfs 75\% alleen. Ook Lewis en Purdie (1988) signaleren het alleen wonen als risicofactor voor "bed blocking". Volgens Wade en Langton-Hewer (1985) en Wachtel et al (1987) verlengt het ontbreken van een sterke informele verzorger de verblijfsduur in het ziekenhuis.

\subsection{PRAKTIJK}

De betekenis van het begrip verkeerd bed is in Nederland vanuit de historie gekoppeld aan de doorstroming vanuit het ziekenhuis naar het verpleeghuis. 
Vanwege het tekort aan verpleeghuisbedden ontstonden er vanaf de 80-er jaren financiële problemen rond patiënten die in het ziekenhuis uitbehandeld waren, maar hun AWBZ-rechten niet konden effectueren, als gevolg van plaatsgebrek in het verpleeghuis. Om problemen die hiermee samenhingen te ondervangen is door de Ziekenfondsraad (1987) de Tijdelijke Vergoedingsregeling Ziekenhuisverblijf (TVZ) in het leven geroepen. Deze regeling geidt slechts voor verpleeghuisgeïndiceerden en dus niet voor personen die na beëindiging van de ziekenhuisindicatie om andere redenen dan capaciteitstekort in het verpleeghuis nog langer in het ziekenhuis verblijven. De TVZ houdt in dat na het beëindigen van de ziekenhuisindicatie niet langer het volledige ziekenhuistarief vergoed wordt, maar slechts het gemiddelde verpleeghuistarief, het zogenaamde $\mathrm{M}-15$ tarief. Dit tarief kan vanaf 28 dagen na beëindiging van het ziekenhuistarief, de zg. frictieperiode, ten laste van de AWBZ worden gebracht. Het probleem van de belemmerde doorstroming vanuit het ziekenhuis naar het verpleeghuis is met deze regeling in financiële zin opgelost door het ziekenhuisbed tijdelijk tot verpleeghuisbed te verklaren, maar het zorgprobleem blijft bestaan. De patiënt ontvangt per definitie niet de meest aangewezen zorg, en bezet een bed dat voor andere doeleinden bestemd is. De Gouw en van Waveren (1993) hebben erop gewezen dat het aantal M15-dagen geen goede maat is voor de problematiek. M15-dagen hebben slechts betrekking op verpleeghuisgeïndiceerde patiënten, waardoor andere vormen van onjuist beddengebruik buiten het gezichtsveld blijven. Bovendien ligt in sommige regio's de wachttijd voor opname in een verpleeghuis onder de 28 dagen, waardoor in het geheel geen M15-dagen ontstaan en een deel van de problematiek verborgen blijft. De TVZ bestaat nog steeds maar deze wordt in de praktijk niet veel meer toegepast. Dit betekent niet dat het onderliggende probleem aan betekenis heeft ingeboet. Veeleer is het zo dat de terugtredende overheid ruirnte biedt aan regionale samenwerkingsverbanden van zorgaanbieders om zelf naar oplossingen te zoeken.

\section{VRAAGSTELLINGEN}

In paragraaf 1 van dit hoofdstuk zijn in algemene bewoordingen de onderzoeksvragen weergegeven die ten grondslag liggen aan dit proefschrift. In het onderstaande worden deze onderzoeksvragen geoperationaliseerd en inhoudelijk verantwoord. Tevens wordt de methode weergegeven die gevolgd is om antwoorden op de vragen te genereren. 
De praktijk wijst wit dat een zeker gedeelte van de in ziekenhuizen opgenomen CVA-patienten te maken krijgt met verkeerde-bedproblematiek. Het is nuttig om de omvang en risicofactoren voor deze problematiek op de netrologische afdeling te kennen. Dit leidde to VRAAGSTELLING 1:

1a Wat is de omvang van de wachtproblematiek, uitgedrukt in verkeerde bedden op de neurologische afdeling van een algemeen ziekenhuis?

ib Wat zijn patiëntkenmerken met voorspellende betekenis voor verkeerde-bedproblematiek op de neurologische afdeling?

Om antwoorden op deze vragen te krijgen werden alle patienten die in 1992 werden opgenomen op de neurologische afdelingen van het Maaslandziekenhuis Sittard-Geleen geregistreerd naar geslacht, leeftijd, woonsituatie, diagnose, en lokalisatie van de laesie (bij CVA-patiënten). Tevens werd bijgehouden welke patiënten in het verkeerde bed kwamen. Bij gebrek aan criteria was het oordeel van de behandelend neuroloog bepalend bij het aanwijzen van verkeerde-beddagen. De antwoorden op deze onderzoeksvraag worden beschreven in hoofdstuk 2 .

Patiënten in het verkeerde bed ontvangen per definitie niet de juiste zorg. Bovendien houden zij een ziekenhuisbed bezet.

In het kader van het streven naar substitutie van zorg, zoals onder meer was beproefd in de projecten die deel uitmaakten van het beleidsprogramma Zorgvernieuwingsprojecten in de Thuiszorg van het Ministerie van WVC, is onderzocht of CVA-patiënten in het verkeerde bed volgens zorgverleners van verschillende disciplines thuis of in een verzorgingshuis verpleegd of verzorgd kunnen worden. Verwacht werd dat over substitutie van deze patienten tussen zorgverleners deels consensus zou bestaan, en dat dit voor een ander gedeelte domein - en haalbaarheidsdiscussies zou opleveren. Dit leidde tot VRAAGSTELIJING 2:

2 a In welke mate en onder welke voorwaarden kan, volgens een panel van zorgverleners van verschillende disciplines, aan CVA-patiënten in het verkeerde bed thuiszorg of zorg in een verzorgingshuis worden geboden als alternatief voor een verblijf in het verkeerde bed (substitutie)?

$2 \mathrm{~b}$ Wat $z i j n$ de voornaamste onderscheidende kenmerken van substitueerbare en niet substitueerbare patiënten?

Deze onderzoeksvragen werden theoretisch benaderd. Er werd een onderzoek opgezet met een panel van zeven zorgverleners: een huisarts, een hoofd verzorging van een instelling voor gezinsverzorging, een hoofdwijkverpleegkundige, een hoofd verzorging van een verzorgingshuis, een verpleeghuis- 
arts, en de twee verpleegkundige hoofden van de neurologische afdelingen in het Maaslandziekenhuis.

Eerst werden de individuele oordelen van de leden van het panel onderzocht, en daarna het op consensus gebaseerde oordeel van de niet-klinische zorgverleners uit het panel. De resultaten zijn beschreven in de hoofdstukken 3 en 4 .

Het materiaal dat nodig was voor de beantwoording van de onderzoeksvragen 1 en 2 was afkomstig uit het project Integraal Regionaal.

Onderzoeksvraag 3 werd gesteld ter validering van het consensus-oordeel van het panel (panel I). Dit panel bestond immers uit individuele en willekeurig gekozen vertegenwoordigers van regionale zorgorganisaties. Hun oordeel over substitutie zou aanzienlijk aan geldigheid winnen indien het gereproduceerd zou kunnen worden door groepen buiten de regio opererende zorgverleners. Hiertoe zijn 40 zorgverleners uit 8 disciplines benaderd (panel II). VRAAGSTELLINGG 3 luidde"

3a Hoe groot is de overeenstemming tussen beide panels?

$3 b$ Hoe is de variatie in overeenstemming tussen de individuele leden van panel III?

3c Hoe is de variatie in overeenstemming tussen de betrokken disciplines in panel II?

3d Hoe is tussen de leden van panel II de variatie in overeenstemming over de verschillendle casus?

$3 \mathrm{e}$ Is de variatie op casusniveau toe te schrijven aan verschillen in informatie in de casusbeschrijvingen?

In hoofdstuk 5 worden de antwoorden op deze vragen beschreven.

Aan het longitudinale element van dit proefschrift werd vorm gegeven via een vervolgonderzoek waarvoor kon worden teruggegrepen op de oorspronkelijke anderzoekscohort. De cohort viel uiteen in twee groepen: CVA-patiënten die in het verkeerde bed hadden gelegen, en CVA-patiënten die zonder verkeerde-bedperiode uit het ziekenhuis waren ontslagen. In dit vervolgonderzoek werd het beloop gedurende 3 jaar na ziekenhuisontslag onder deze beide patiëntencategorieën onderzocht.

Onder de CVA-patiënten die in het verkeerde bed hadden gelegen werd de geldigheid van het consensus-oordeel van het panel onderzocht voor de uitkomsten op langere termijn. Het consensus-oordeel van het panel zou naar onze mening aan waarde wimmen wanneer het niet alleen nuttig was om 
ad hoc te differentiëren naar theoretisch mogelijke uitstroomcategorieën uit het ziekenhuis, maar indien er ook een relatie zou blijken te bestaan tussen deze uitstroomcategorieën en de uitkomsten op lange termijn. Als voornaamste lange termijn uitkomst werd gekozen voor het al dan niet in leven zijn 3 jaar na ziekenhuisopname. Dit resulteerde in VRAAGSTELLING 4:

4a Hoeveel verkeerde-bedpatiënten met CVA zijn 3 jaar na ontslag uit het ziekenhuis nog in leven, en welke routes door het zorgsysteem hebben zij afgelegd?

$4 \mathrm{~b}$ Bestaat er een verband tussen het paneloordeel en overleving na 3 jaar?

$4 c$ Kunnen aan de uitkomsten op lange termijn, in combinatie met het paneloordeel indicaties worden ontleend over de omvang van de mogelijke substitutie?

De resultaten van dit deel van het vervolgonderzoek zijn beschreven in hoofdstuk 6.

De cohort omvatte ook een aantal CVA-patiënten die vanuit het ziekenhuis zonder verkeerde-bedsituatie naar huis werden ontslagen. Onder deze groep werd een vervolgonderzoek ingesteld om de zorgbehoefte en het gebruik van voorzieningen gedurende de 3 jaar na ziekenhuisontslag vast te stellen. Dit resulteerde in VRAAGSTELLING 5:

5a Welke zorg ontvingen CVA-patiënten die zonder verkeerde-bedperiode uit het ziekenhuis naar huis werden ontslagen gedurende de 3 jaar volgend op ziekenhuisontslag,

$5 b$ Welke problemen en beperkingen ondervinden deze patiënten 3 jaar na ontslag uit het ziekenhuis in de thuissituatie?

$5 \mathrm{c}$ In welke mate ondervinden familiezorgers emotionele problemen met de verzorging van hun familielid, en in welke mate ervaren zij de familiezorg als zwaar?

5d. Welke factoren zijn gerelateerd met het gebruik van familie- en professionele zorg en met de ervaren zorgzwaarte?

Rechtsstreeks vanuit het ziekenhuis naar huis ontslagen patiënten en hun centrale familiezorgers werden na 3 jaar aangeschreven en verzocht om mee te doen aan een vervolgonderzoek. De patiënten werd gevraagd welke beperkingen zij ondervonden en welke zorg zij in de thuissituatie ontvangen hadden gedurende de 3 jaar na ziekenhuisontslag. Aan de centrale familiezorgers werd gevraagd of zij de familiezorg als zwaar ervoeren. 
In hoofdstuk 7 worden de resultaten van dit gedeelte van het vervolgonderzoek beschreven.

\section{LITERATUUR}

1. Bergman L., Meulen J.H.P. van der, Limburg M., Habbema J.D.F. Kosten van levenslange zorg voor patiènten met een beroerte in Nederland. Tijdschr Soc Gezondheidsz 1997; 75: 498-505.

2. Bonita R., Beaglehole R., Asplund $K$. The worldwide problem of stroke. Current opinion in neurology 1994; 7: 5-10.

3. Bos G.A.M. van den. Zorgen van en voor chronisch zieken [dissertatie]. Utrecht/Antwerpen: Bohn, Scheltema en Holkema, 1989.

4. Brunet de Rochebrune $A_{n}$, Dijk P. van. 'Stroke service' gezien vanuit een zorgverzekeraar. Tijdschr Soc Gezondheidsz 1997; 75: 525-6.

5. Burley L.E., Currie C.T., Smith R.G., Williamson J. Contribution from geriatric medicine within acute medical wards. Br Med I 1979;2:90-2.

6. Chambers B.R., Norris J.W., Shurvell B.L., Hachinski V.C. Prognosis of acute stroke. Neurology $1987 ; 37: 221-5$.

7. Coid J., Crome P. Bed blocking in Bromley. Br Med J 1986; 292: 1253-6.

8. College voor Ziekenhuisvoorzieningen. Advies inzake planningsnormen voor de sector verpleeghuizen. Utrecht 1992.

9. C.B.O. Consensus cerebrovasculair accident. Utrecht, 1991.

10. Dennis M. Stroke services. The Lancet 1992; 339: 793-5.

11. Dennis M., Langhorne P. So stroke units save lives: where do we go from here? Br Med I 1994; 309: 1273-7.

12. Donaldson L.J. Characteristics of elderly people misplaced in hospitals and homes. Publ Hlth 1983;97: 257-61.

13. Fields S.D., Mackenzie C.R., Charlson M.E., Sax F.L. Cognitive impairment, can it predict the course of hospitalized patients? JAGS 1986; 34: 579-85.

14. Franke C.L. Het belang van 'stroke service' voor de toekomst. "I"ijdschr Soc Gezondheidsz 1997; 75: 519-21.

15. Giertman P.M., Restuccia J.D. The appropriateness evaluation protocol: a technique for assessing unnecessary days of hospital cure. Medical Care 1981; 19: 855-71.

16. Ghouat E1 P. Verpleeghuispatiënten in een ziekenhuisbed; een analyse van de groep patiènten die vanuit een ziekenhuís doorstroomt naar een verpleeghuis. Signet 1987; 3: 18-20.

17. Glass R.I., Weiner M.S. Seeking a social disposition for the medical patient: CAAST, at simple and objective clinical index. Medical Care 1976; 14: 637-41. 
1.8. Gouw J.M.M. de, Waveren L. van. Verkeerde-bedproblematiek. Den Haag: Provinciale Raad voor de Volksgezondheid Zuid-Holland, 1993.

19. Gruenberg $\mathbb{L}$.W. Willemain T.R. Hospital discharge queues in Massachusetts. Medical Care 1982; 20: 188-200.

20. Haan R. de, Limburg M., Meulen J. van der Bos G.A.M. van den. Use of health care services after stroke. Qual Health Care 1994; 2: 222-7.

21. Hall D., Bytheway B. The blocked bed, definition of a problem. Soc Sci Med 1982; 16; 1985-91.

22. Hazell K. Social and medical problems of the elderly. Hutchinson, London 1965 (rev. ed.).

23. Herman B., Leyten A.C.M., Luijk J.H. van, Frenken C.W.G.M., Coul A.A.W. op de, Schulte B.P.M. Epidemiology of stroke in Tilburg, The Netherlands. Stroke 1981; 13: $334-9$.

24. Herman J.M., Culpepper L. Franks P. Patterns of utilization, disposition and length of stay in a community hospital setting. IAGS 1984; 32:421-6.

25. Hermans E. Project "Integraal Regionaal"; zorgvernieuwing in de Westelijke Mijnstreek. Medisch Contact 1992; 47:435-8.

26. Jones M.E.D., Golding A.M.B. Placing long-stay patients in private nursing homes. Public Health 1987; 101: 169-78.

27. Lewis H., Purdie G. The blocked bed; a prospective study. NZ Med J 1988; 101:575-7

28. Limburg M. Gestructureerde zorg voor patiënten met een beroerte: 'stroke units' en "transmurale stroke services". Ned Tijdschr Geneeskd 1997; 141: 566-7.

29. Lodder J., Bouter L.M. Toekomstige aantallen patiënten met cerebrovasculair accident in Nederland. Ned Tijdschr Geneeskd 1992; 136: 425-7.

30. Logan R.F.L., Ashley J.S.A., Klein R.E., Robson D.M. Dynamics of medical care. Lon don: London school of Hygiene and Tropical Medicine, 1972.

31. Marchette L, Holloman F, Length of stay; significant variables. IONA 1986; 16: 12-20.

32. Markson E.W., SteelK., Kane E. Administratively mecessary days: more than an administrative problem. The gerontologist $1983 ; 23: 486+93$.

33. Maguire P.A., Taylor I.C., Stout R.W. Elderly patients in acute medical wards: factors predicting length of stay in hospital. Br Med J 1986; 292: 1251-3.

34. McAlpine C.J. Unblocking beds: a geriatric unit's experience with transferred patients. Br Med J 1979;2:646-49.

35. McArdle C., Wylie J.C., Alexander W.D. Geriatric patients in an acute medical ward. $\mathrm{Br}$ Med I $1975 ; 4: 5681-9$.

36. Meer $\mathbf{K}$. van der, Smith R.J.A. Cerebrovasculaire aandoeningen gepeild. Utrecht: Nederlands Instituut voor Eerstelijnsgezondheidszorg NIVEL, 1990.

37. Meiners M.R., Coffey R.M. Hospital DRG's and the need for long-term care services: an empirical analysis. Fealth Services Res 1985; $20: 359-84$. 
38. Meyboom-de Jong B., Buis J (eindredactie.) Zorg na een beroerte. Den Haag: Nederlandse Hartstichting 1995.

39. Ministerie van Welzijn, Volksgezondheid en Cultuur. Programma Zorgvernieuwingsprojecten Thuiszorg. Rijswijk 1989.

40. Murphy E.W. Blocked bedis. Br Med J 1977;1: 1395-6.

41. Nationale Raad voor de Volksgezondheid/College voor Ziekenhuisvoorzieningen. Verkeerde-bedproblematiek. Zoetermeer/Utrecht, 1995.

42. Nederlandse Hartstichting. Hart- en vaatziekten in Nederland in 1996; cjjfers over ziekte en sterfte. Den Haag 1996.

43. NWO, Gebied Medische Wetenschappen. Kaderprogramma Nederlands Hersendecennium. Den Haag 1995

44. Pan European Consensus Meeting on Stroke Management. Copenhagen: WHO Regional Office for Europe, 1996.

45. Posner J.R., Lin H.W. Effects of age on length of hospital stay in a low income popula tion. Medical Care 1975; 13(10): 855.

46. Restuccia J.D., Holloway D.C. Barriers to appropriate utilization of an acute facility. Medical Care $1976 ; 14: 559-73$.

47. Rosenfeld L.S., Goldmann F., Kaprio L.A. Reasons for prolonged hospital stay. J Chron Dis 1957; 141-52.

48. Rosser R.M., Chir B. The reliability and application of clinical judgement in evaluating the use of hospital beds. Medical Care 1976; 14: 39-47.

49. Rubin S.G., Davies G.H. Bed blocking by elderly patients in general-hospital wards. Age and Ageing 1975; 4: 142-7.

50. Sacco R.L. Risk factors and outcome for ischemic stroke. Neurology $1995 ; 45$ (suppl 1 ): S10-S》4.

51. Schuling J. Stroke patients in general practice [dissertatie], Groningen: Rijksunivers]teit Groningen, 1993.

52. Schure L. Partners van CVA-patiënten [dissertatie]. Groningen: Rijksuniversiteit Groningen, 1994.

53. Seymour D.G., Pringle R. Elderly patients in a general surgical unit do they block beds? Br Med I 1982; 284: 1921-3.

54. Shapiro E., Roos N.P., Kavanagh S. Long term patients in acute care beds: is there at cure? Gerontollogist 1980; $20: 342-9$.

55. Shuaib A. Boyle C. Stroke in the elderly. Current opinion in neurology $1994 ; 7: 41-7$.

56. Sickinger P. Notitie Knelpunten CVA gehandicapten en partners. Bunnik, 1992.

57. Siu A.L., Sonnenberg F.A., Manning W.G. Inappropriate use of hospitals in a randomized trial of health insurance plans. N Eng J Med 1986; 315: 1259.

5i8. Sloane P.D., Redding R., Wittlin L. Longest-term placement problems in an acute care hospital. J Chron Dis 1981,; 34: 285-90. 
59. Stolker D.H.C.M. Bos G.A.M. van den, Klazinga N.S., Koopmanschap M.A., Senten M.C.M. 'Stroke service': een bewezen dienst. Tijdschr Soc Gezondheidsz 1997; 75: 518-9.

60. Straten A. van, Meulen J.H.P. van der, Bos G.A.M. van den, Limburg M. "Wachtdagen" in het ziekenhuis van patiënten met een beroerte. Tijdschr Soc Gezondheidsz 1997; 75: 506-10.

61. Tellis-Nayak V., Tellis-Nayak M. An alternative level of care, the prospective payment system and the challenge of extended care. Soc Sci Med 1986; 23:665-71.

62. Vosbeek R.W.M. "Verkeerde-bed" problematiek; inventarisatie van een actueel probleem. Nijmegen: Kath. Universiteit Nijmegen, 1990.

63. Wachtel T.J. Fulton J.P., Goldfarb J. Early prediction of discharge disposition after hospitalization. Gerontologist 1987; 27: 98-103.

64. Wade D.T., Langton-Hewer R. Hospital admission for acute stroke: who, for how long, and to what effect? J Epidemiology and Comm Health $1985 ; 39: 347-52$.

65. Weissert W.G., Matthews C. Determinants of hospital-to-nursing home placement delays: a pilot study. Health Services Research 1988; 23: 620-47.

66. WHO Spec. Report. Stroke-1989: recommendations on strake prevention, diagnosis and therapy. Stroke 1989; 20: 1407-31.

67. Wijdeven C.E.F. De verkeerde bed problematiek; een onderzoek naar de omvang van de verkeerde bed problematiek en naar factoren die hierop van invloed zijn. Maastricht: Rijksuniversiteit Limburg, 1989.

68. Ziekenfondsraad. Tijdelijke vergoeding het "verkeerde bed". Amstelveen, 1987.

69. Zimmer J.G. Length of stay and hospital bed misutilization. Medical Care 1974; 12 : 453-62.

70. Zimmer J.G. Groth-Juncker A, McCusker J. A randomized controlled study of a home healtly care team. Am J Publ Hith 1985; 75: 134-41. 
HOOFDSTUK 2

Patiëntkenmerken met voorspellende betekenis voor verkeerde-bedproblematiek op de neurologische afdeling van een algemeen ziekenhuis

E. Hermans, H.W.M. Anten, J.P.M. Diederiks, H. Philipsen, H.W.J.M. Beeren

Gepubliceerd in: Nederlands Tijdschrift voor Geneeskunde 1995; 139: 89-4 


\title{
SAMENVATTING
}

\author{
TITEL
}

Patiëntkenmerken met voorspellende betekenis voor verkeerde-bedproblematiek op de neurologische afdeling van een algemeen ziekenhuis.

DOEL

Het bepalen van de omvang en voorspellende patiëntkenmerken van de verkeerde-bedproblematiek (het bezetten van ziekenhuisbedden door patienten die geen medisch-specialistische hulp meer nodig hebben) op de neurologische afdeling van een algemeen ziekenhuis.

\section{OPZET}

Prospectief cohortonderzoek.

\section{PLAATS}

Maaslandziekenhuis Sittard-Geleen (locatie Sittard).

\section{METHODE}

Gedurende een jaar werd onder het volledige klinische patiëntenbestand van 2 neurologische afdelingen van elke patiënt geregistreerd: hoofddiagnose, leeftijd, geslacht, woonsituatie, localisatie van de laesie (bij CVA-patiënten) en verkeerd bed. Via logistische regressieanalyse werden de voorspellende patiëntkenmerken voor verkeerde bedden vastgesteld.

\section{RESULTATEN}

Er werden 1088 patiënten geregistreerd, van wie $21 \%$ met een CVA. Bij $10 \%$ van de geregistreerde patiènten was er sprake van een verkeerd bed, van hen had $86 \%$ de diagnose CVA. Van alle CVA-patiënten kwam $40 \%$ in een verkeerd bed. Van alle voor CVA-patiënten genoteerde verpleegdagen bestond $20 \%$ uit verkeerde-beddagen. Bij de CVA-patiënten hingen het geslacht (vrouwen), de leeftijd ( $\geq 70$ jaar) en de localisatie van de laesie significant samen met het 
verkeerde-bedprobleem. De belangrijkste zelfstandige voorspellers van verkeerde bedden waren de diagnose CVA en een leeftijd vanaf 70 jaar.

\section{CONCLUSIES}

Neurologische patiënten met een verhoogde kans in een verkeerd bed terecht te komen bevinden zich met name onder CVA-patiënten. Aangezien $20 \%$ van de door CVA-patiënten gegenereerde verpleegdagen verkeerde-beddagen betrof, zijn verkorting van opnameduur en verbetering van thuiszorg gewenst. 


\section{ABSTRACT}

\section{TITLE}

Pattent characteristics predictive for bed-blocking in neurological wards in a general hospital.

\section{OBJECTIVE}

To determine the extent and the prognostic patient characteristics for bed-blocking (hospital beds occupied by patients who no longer need specialist medical treatment) in two neurological wards of a general hospital..

\section{DESIGN}

Prospective cohort study.

\section{SETTING}

Maasland hospital Sittard-Geleen (location Sittard).

\section{METHOD}

During one year each patient of the complete patient population of two neurological wards was registered relating to: main diagnosis, age, sex, living situation, lesion localization (only for cerebrovascular accident(CVA) patients) and bed-blocking. The predictive patient characteristics for bed-blocking were determined by logistic regression analysis.

\section{RESULTS}

1088 patients were registered, of whom $21 \%$ with CVA.

In $10 \%$ of of the registered patients bed-blocking occurred, $86 \%$ of these had the diagnosis of CVA. Of all CVA-patients $40 \%$ became bed-blockers of all nursing days of CVA-patients $20 \%$ were bed-blocking days. Among the CVA-patients sex (female), age (270) and the localization of the lesion were found to be significant risk factors for bed-blocking. The main patient characteristics predictive for bed-blocking were the diagnosis of CVA and age $(270)$. 


\section{CONCLUSION}

Neurological patients with an increased risk to end up in a blocked bed are mainly found among CVA patients. Since $20 \%$ of the nursing days of CVA patients were bed-blocking days, shortening of hospitalization time and improvement of home care is recommended. 


\section{INLEIDING}

Al jaren kampen ziekenhuizen -zowel in Nederland als elders- met de verkeerde-bedproblematiek. De term verkeerd bed wordt in Nederland meestal gebruikt in de verzekeringstechnische zin, waarbij gedoeld wordt op een patiënt met een verpleeghuisindicatie die nog in het ziekenhuis verblijft (Ziekenfondsraad 1987). In de internationale literatuur wordt meestal van. blocked bed gesproken (Hall \& Bytheway 1982). In dit artikel verstaan wij onder een verkeerd bed: een bed dat bezet wordt door een patiënt die geen medisch-specialistische hulp meer nodig heeft waarvoor ziekenhuisverblijf nodig is, en die nog in het ziekenhuis verblijft in afwachting van opname in een residentiële voorziening of van terugplaatsing naar de thuissituatie. Uit een beperkte rondvraag onder in Nederlandse ziekenhuizen werkzame neurologen is ons gebleken dat zij dezelfde begripsdefinitie hanteren. In de internationale literatuur worden cerebrovasculaire aandoeningen (CVA's) vaak genoemd als risicocategorie voor blocked beds (Coid \& Crome 1986, Lewis \& Purdie 1988, Marchette \& Holloman 1986). Het probleem komt vaker voor onder personen van hoge leeftijd

(Coid \& Crome 1986, Lewis \& Purdie 1988, Marchette \& Holloman 1986 , Murphy 1977), vrouwen (Coid \& Crome 1986, Murphy 1977) en alleenwonenden (Coid \& Crome 1986, Lewis \& Purdie 1988, Murphy 1977). Nederlands onderzoek naar het probleem is slechts beperkt voorhanden, het is voornamelijk inventariserend van aard, en gaat uit van de verzekeringstechnische definitie van verkeerde bedden. Ook hier wordt CVA als belangrijke diagnosecategorie in verband met verkeerde bedden genoemd (Wijdeven 1989); tevens komt het belang van de factor leeftijd naar voren (El Ghouat 1987). Voorspellingen over de toekomstige ziektelast tengevolge van CVA lopen viteen. Lodder et al voorspellen dat het percentage eerste gevallen van CVA tot het jaar 2020 met 40 tot $62 \%$ van het aantal in 1992 zal toenemen (Lodder \& Bouter 1992). Bovendien wijzen zij op een mogelijkstijgende CVA-incidentie. Niessen et al (1993) gaan daarentegen uit van een dalende incidentie waarvan de effecten slechts deels teniet zullen worden gedaan door de vergrijzing.

Wij hebben met betrekking tot deze problematiek een onderzoek opgezet met de volgende tweeledige vraagstelling:

1 Wat is de omwang van de verkeerde-bedproblematiek op de neurologische afdeling van een algemeen ziekenhuis op jaarbasis?

2. Zijn er binnen het specialisme neurologie diagnose- en/of persoonsgebonden kenmerken aanwijsbaar die met het verkeerde-bedprobleem 
samenhangen of die het ontstaan van een verkeerde-bedsituatie voorspellen?

De onderzochte kenmerken waren: diagnose, geslacht, leeftijd, woonsituatie en -bij CVA-patiënten- de localisatie van de laesie. De werking van de variabelen localisatie van de laesie en woonsituatie werden getest vanuit de hypothesen dat letsels in de linker hemisfeer, onder meer vanwege de daarbij vaak optredende taalstoornissen, en alleenwonend-zijn frequenter tot een verkeerde-bedsituatie zullen leiden.

\section{METHODE}

Het onderzoek duurde van 1 januari tot en met 31 december 1992, en werd verricht onder het volledige klinische patiëntenbestand van 2 (van de 3) neurologie-afdelingen van het Maaslandziekenhuis Sittard-Geleen (beide op de locatie Sittard), waar in de loop van 1992 alle opnamen wegens CVA werden geconcentreerd.

Elke opgenomen patiënt werd geregistreerd naar diagnose, leeftijd, geslacht, woonsituatie en -bij CVA-patiënten- de localisatie van de laesie. De diagnose CVA en de localisatie van de laesie werden bepaald op basis van computertomografisch (CT) onderzoek. De localisatie van de laesie werd vastgesteld in termen van stroomgebieden van cerebrale arteriae. Het moment waarop de behandeling was voltooid en daarmee het moment waarop de patiënt verkeerde-bedpatiënt werd, werd door de behandelend neuroloog vastgesteld naar aanleiding van de uitkomsten van de patiëntbesprekingen op de afdeling. Criteria waren niet vooraf gespecificeerd.

Wij hanteerden als definitie van een CVA: "plotseling ontstane klinische verschijnselen van een focale stoomis van de hersenfunktie met een duurvan. meer dan 24 uur of eindigend met de dood, waarvoor geen andere oorzaak aanwijsbaar lijkt dan een vasculaire stoomis." (WHO 1989). Bij de analyses maakten wij geen onderscheid tussen eerste- en recidief CVA's, en evenmin tussen eerste opnamen en heropnamen.

De gegevens werden tweevoudig en multipel geanalyseerd met behulp van het statistisch softwarepakket SPSS (Statistical Package Social Sciences International B.V., Gorinchem). Om de relatie tussen verkeerde bedden en een patiëntkenmerk te analyseren werden odds ratio's (OR) berekend. Multipele predictieanalyse ten aanzien van verkeerde-bedproblematiek werd uitgevoerd met logistische regressieanalyse. 


\section{RESULTATEN}

Patiènten . De onderzoekscohort omvatte 1088 patiënten, waarvan 232 (21\%) met diagnose CVA. CVA was hiermee na lumbale en cervicale pathologie (35\% van het totaal aantal opnamen) de grootste neurologische opnamecategorie. De opgenomen CVA-patiẻnten waren gemiddeld 71 jaar oud (uitersten: $30-93) ; 123(53 \%)$ waren vrouwen; $195(84 \%)$ werden opgenomen vanuit de thuissituatie, 51 hiervan $(26 \%)$ woonden alleen, waarvan 31 (62\%) vrouwen.

Zestig patienten onder wie 40 CVA-patiènten (1.7\% van de opnamecategorie) overleden in het ziekenhuis voordat er sprake kon zijn van een verkeerd bed; dat wil zeggen: ze overleden in de periode dat specialistische zorg nog geindiceerd was. Dit kwam vaker voor onder patiënten met letsel in het stroomgebied van de rechter Arteria Cerebri Media (48\%) dan onder patiënten met elders gelocaliseerd letsel $(23 \%)(\mathrm{p}<.01)$.

Aantal verkeerde-beddagen. Met betrekking tot verkeerde-bedproblematiek bleek bij uitstek de groep met de diagnose CVA van belang te zijn. Er kwamen gedurende het onderzoeksjaar in totaal 106 verkeerde-bedpatiënten (10\% van het aantal opnamen) voor op de beide afdelingen; van hen hadden 91 $(86 \%)$ de diagnose CVA. Van alle opgenomen CVA-patiënten kwam $40 \%$ in een verkeerd bed; met uitsluiting van de vroegtijdig overledenen zelfs $47 \%$. Geen andere diagnosegroep haalde bij benadering dergelijke hoge percentages verkeerd bed. De eerstvolgende diagnosegroep in dit verband was "hersentumor"; hiervan kwam $28 \%$ in het verkeerde bed. Deze groep legde getalsmatig echter weinig gewicht in de schaal ( $2 \%$ van het totaal aantal opnamen). De CVA-patiènten kenden een gemiddelde opnameduur van 36 dagen (1-199); voor degenen die niet in een verkeerd bed kwamen was dit 17 dagen en woor hen die wel in een verkeerd bed kwamen was dit 65 dagen, waarvan 38 verkeerde-beddagen. Patiënten die naar het verpleeghuis werden ontslagen verbleven gemiddeld 53 dagen in het verkeerde bed; patienten die vanuit het verkeer de bed alsnog naar huis werden ontslagen gemiddeld 18 dagen. In totaal waren er door de verkeerde-bedpatiënten met de diagnose CVA 3458 verkeerde-beddagen, dat is $20 \%$ van alle neurologische verpleegdagen.

Patiëntkenmerken en verkeerd bed. Het verband tussen verkeerde bedden en de variabelen diagnose, leeftijd $\mathrm{d}_{\sharp}$ geslacht, woonsituatie en localisatie van de laesie staat in tabel 1 . Het verband met diagnose werd getest binnen de groep van alle opgenomen patiënten, het verband met de 4 laatstgenoemde variabellen alleen binnen de CVA-groep. De gegevens van patiënten met 
TABEL 1、 SAMENHANG VAN PATEENTKENMERKEN MET VERKEERDE-BEDPROBLEMATIEK

\begin{tabular}{|c|c|c|c|}
\hline Kenmerk & $\begin{array}{l}\text { patiènten (\%) } \\
\text { in verkeerde bed }\end{array}$ & $O R$ & $95 \% \mathrm{BI}$ \\
\hline Alle patüënten (n=1028) & $106(10)$ & & \\
\hline CWA patiënten $(n=192)$ & $91(47)$ & 50,0 & $27,41-91,87$ \\
\hline Patienten met overige diagnosen $(n=836)$ & $15(2)$ & & \\
\hline CVA patiënten zonder afw. in ACM re. (n=111) & $67(60)$ & 1,5 & $1,06-2,10$ \\
\hline CWA patiënten met afw. in ACMre. $(n=40)^{3}$ & $16(40)$ & & \\
\hline Vrouwelijke CVA-patiènten $(n=101)$ & $57(56)$ & 2,1 & $1,19-3,81$ \\
\hline Manmelijke CVA-patiënten $(n=91)$ & $34(37)$ & & \\
\hline CVA-patienten $\geq 70$ jaar $(n=113)$ & $73(65)$ & 6,1 & $1,17-11,69$ \\
\hline CVA-patienten $<70$ jaar $(n=79)$ & $18(23)$ & & \\
\hline Alleenwonende CWA-patiënten $(\mathrm{r}=48$ ) & $26(54)$ & 1,3 & $0,67-2,50$ \\
\hline Met anderen wonende CVA-patiënten $(n=135)^{2}$ & $64(47)$ & & \\
\hline
\end{tabular}

$O R=$ Odds Ratio; $B I=$ Betrouwbaarheidsinterval;; ${ }^{1}$ exclusief 'reversible ischaemic neurological deficit' (daarbij wordt wel aan de WHO-criteria voor CVA voldaan, maar een laesie-localisatie kan niet worden vastgesteld), overplaatsing naar elders, laesie-localisatie miet vastgesteld of onbekend; "exclusief ontbrekende waarden.

niet-neurologische diagnosen, alsmede die van patiënten die tijdens hun verblijf in het ziekenhuis zijn overleden voordat sprake was van een verkeerd bed, werden buiten de analyses gehouden.

Gemeten onder alle opgenomen patiënten vonden wij een significant verband tussen verkeerd bed en de diagnose CVA (OR: 50,0). Binnen de groep van CVA-patiënten werden significante verbanden vastgesteld tussen verkeerd bed en leeftijd $(\geq 70 ;$ OR: 6,1 ), geslacht (voor vrouwen bedroeg de OR: 2,1 ) en localisatie van de laesie (voor patienten met een afwijking niet in het stroomgebied van de rechter Arteria Cerebri Media was de OR 2,0).

Tenslotte werd zowel voor de totale patiëntenpopulatie als voor de CVA-groep multipele predictieanalyse ten aanzien van verkeerde-bedproblematiek uitgevoerd. De resultaten staan in de tabellen 2-5.

Logistische regressieanalyse binnen de totale patiëntengroep (tabel 2) liet zien dat de voorspelling of iemand al dan niet in een verkeerd bed zou komen, overheerst werd door de variabelen diagnose (bij CVA was er een grotere kans op verkeerd bed) en leeftijd (bij patiënten $\geq 70$ jaar was die kans groter). Dat een patiënt niet in een verkeerd bed terecht zou komen, werd door het model beter voorspeld $(96,4 \%)$, blijkens de predictieve waarde van een negatieve uitslag (tabel 3), dan dat hij er wel in terecht zou komen $(64,6 \%)$. Binnen de 
TABEL 2. RESULTATEN VAN LOGISTISCHE REGRESSTEANALYSE AANGAANDE VERKEERDE BEDDEN ONDER ALLE PATIËNTEN $(\mathrm{n}=1028)$

\begin{tabular}{llll}
\hline & $B($ s.e) & OR & 95\% BI \\
\hline Diagnose (CvA vs. overige) & $3,36(0,32)$ & 28,67 & $15,4-53,9$ \\
Leeftijd (270 jr.ws. $<70 \mathrm{jr}$ ) & $1,79(0,28)$ & 6,02 & $3,46-10,37$ \\
\hline
\end{tabular}

$O R=$ Odds Ratio; $B I=$ Betrouwbaarheidsintervat.

TABEL 3. $2 \times 2$ TABEL VAN VERKEERDE-BEDPROBLEMATIEK BIJ 1028 PATIËNTEN OP TWEE NEUROLOGISCHE AFDELINGEN

\begin{tabular}{|c|c|c|c|}
\hline \multirow{2}{*}{$\begin{array}{l}\text { Verkeerde bedden } \\
\text { volgens madel }\end{array}$} & \multicolumn{3}{|c|}{ Verkeerde bedden volgens waameming } \\
\hline & WEL & NIET & TOTAAL \\
\hline WEl. & 73 & 40 & 113 \\
\hline NIET $^{3}$ & 33 & 879 & 912 \\
\hline TOTAAL & 106 & 919 & $1025^{4}$ \\
\hline
\end{tabular}

${ }^{1}$ Regressiemodel van tabel $2 ;{ }^{2}$ Predictieve waarde wan positieve uitslag: $64,6 \%$; ${ }^{3}$ Predictieve waarde van neigatieve uitslag: $96,4 \%$; "Exclusief 3 patiënten van wie de leeftijd niet bekend was.

TABEL 4. RESULTATEN VAN LOGISTISCHE REGRESSIEANALYSE AANGAANDE VERKEERDE BEDDEM ONDER CVAPATIËNTEN $(n=151)$

\begin{tabular}{llll} 
& B (s.e) & OR & $95 \%$ BI \\
\hline Leeftijd $(\geq 70$ v5. <70) & $1,60(0,38)$ & 4,97 & $2,35-10,43$ \\
Geslacht X laesie-Localisatie & $0,36(0,16)$ & 1,43 & $1,05-1,96$ \\
\hline
\end{tabular}

$\mathrm{OR}=0 \mathrm{dds}$ Ratio; $\mathrm{BI}=$ Betrouwbarheidsinterval.

TABEL 5. 2X2 TABEL VAN VERKEERDE-BEDPROBLEMATIEK BIJ 192 CVA-PATYËNTEN OP TWEE NEUROLOGISCHE AFDELINGEN

\begin{tabular}{|c|c|c|c|}
\hline \multirow{2}{*}{$\begin{array}{l}\text { Verkeerde bedden } \\
\text { volgens mode } 1\end{array}$} & \multicolumn{3}{|c|}{ Verkeerde beddem volgens waameming } \\
\hline & WEL & NIET & TOTAAL \\
\hline WEL $L^{2}$ & 65 & 17 & 82 \\
\hline NIET ${ }^{3}$ & 27 & 42 & 69 \\
\hline TOTAAL & 92 & 59 & $151^{4}$ \\
\hline
\end{tabular}

${ }^{1}$ Regressiemodel valn tabel $4 ;{ }^{2}$ Predictieve waarde van positieve uitslag: $79,3 \%$; ${ }^{3}$ Predictieve waarde van negatieve uitslag: 60,9\%* "Van 41 van de oorspronkelijk 192 patiënten ontbraken enkele gegevens. 
groep CVA-patiënten was de predictie genuanceerder: de variabele leeftijd was hier weliswaar de overheersende voorspeller voor verblijf in een verkeerd bed, maar er trad een significant interactie-effect op tussen de variabelen geslacht en laesie-localisatie: vrouwelijke patiënten met een laesie die niet gelocaliseerd was in het stroomgebied van de rechter Arteria Cerebri Media, hadden een grotere kans om in een verkeerd bed terecht te komen. Binnen de CVA-groep kon, in tegenstelling tot binnen de totale patiëntengroep, het wel in een verkeerd bed terecht komen aanzienlijk beter voorspeld worden $(79,3 \%)$ dan het niet in een verkeerd bed komen $(60,9 \%)$.

\section{DISCUSSIE}

Hoewel wij onderzoek deden in slechts eén ziekenhuis, hebben wij niet de indruk dat de praktijk op de neurologische afdelingen van dit ziekenhuis afwijkt van die in andere ziekenhuizen. Wij gaan er dan ook van uit dat onze bevindingen indicatief zijn voor de Nederlandse situatie.

Van alle neurologische opnamen resulteerde $10 \%$ in een verkeerdebedsituatie. Verontrustend achten wij het feit dat deze verkeerde-bedpatiënten voor $86 \%$ afkomstig waren uit één diagnose-categorie (CVA), en dat zij een zeer lange verblijfsduur van gemiddeld 65 dagen in het ziekenhuis hadden. Van alle opgenomen patiënten met een CVA -die niet tijdens de acute fase in het ziekenhuis overleden- kwam $47 \%$ in het verkeerde bed en $20 \%$ van alle neurologische verpleegdagen bestond uit verkeerde-beddagen. Toepassing van dit percentage op de Nederlandse situatie (met 1.261.115 neurologische verpleegdagen in algemene ziekenhuizen in 1992) (NZI 1993)betekent dat er binnen het specialisme neurologie in algemene ziekenhuizen jaarlijks een kwart miljoen medisch onnodige verpleegdagen wordt gerealiseerd. Bij ongewijzigd beleid en in samenhang met andere factoren -zoals de vergrijzing en de voortgaande reducties van het aantal bedden in algemene ziekenhuizen-kan deze situatie een bedreiging gaan inhouden voor het functioneren van de neurologische afdeling in het algemene ziekenhuis.

Het blijkt goed mogelijk te zijn om factoren aan te wijzen die met het verkeerde-bedprobleem samenhangen: de diagnose CVA, een leeftijd $\geq 70$ jaar, vrouw-zijn, en een laesie die niet is gelocaliseerd in het stroomgebied van de rechter Arteria Cerebri Media. Tevens vonden wij dat patiënten met een wel op die plaats gelocaliseerd letsel significant vaker overleden tijdens de acute fase. De betekenis van dit letsel is moeilijk aan te geven. Mogelijk gaat een

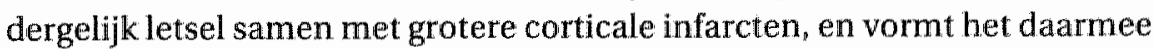


een voorspellende variabele van de kans op overlijden. Het verwachte verband tussen de verkeerde-bedsituatie en in de linker hemisfeer gelocaliseerde laesies kon als zodanig niet worden aangetoond.

Als zelfstandige voorspellende variabelen van verkeerde-bedsituatie kwamen vooral de diagnose CVA, leeftijd $\geq 70$ jaar en de interactie tussen de variabelen geslacht en localisatie van de laesie (vrouwen met een niet in de rechter Arteria Cerebri Media gelocaliseerd letsel) naar voren. Voordat aan deze bevindingen belangrijke voorspellende waarde wordt toegekend, is het van belang dat deze in prospectief replicatie-onderzoek bevestigd worden. Aanbevolen wordt om hierbij zeker ook de betekenis van de localisatie van de laesie meer in detail te onderzoeken. Intussen lijkt de verkeerde-bedsituatie onder CVA-patiënten voldoende reden voor gecoördineerde inspanningen van klinische- en thuiszorg om de (na)zorg voor CVA-patiënten in de thuissituatie verder te verbeteren, en alle mogelijkheden te benutten om ziekenhuisopnamen wegens CVA te bekorten. Met behulp van ons predictieve model kunnen patiënten met een verhoogde kans in een verkeerd bed terecht te komen, vroegtijdig worden geïdentificeerd, waardoor reeds in een vroeg stadium kan worden geanticipeerd op ontslagproblemen die na voltooiing van de medische behandeling te verwachten zijn.

\section{DANKBETUIGING}

Wij danken de heer A. Schepers, hoofdverpleegkundige in het Maaslandziekenhuis Sittard-Geleen (locatie Sittard) voor zijn bijdrage in de gegevensverzameling.

\section{LITERATUUR}

1. Advies tijdelijke vergoeding het "verkeerde bed". Amstelveen: Ziekenfondsraad, 1987.

2. Hall D., Bytheway B. The blocked bed, definition of a problem. Soc Sci Med 1982; 16: 1985-91.

3. Coid J., Crome P. Bed blocking in Bromley. Br Med I [Clin Res] 1986; 292: 1253-6.

4. Lewis H., Purdie G. The blocked bed: a prospective study. N ZMed J 1988; 101:575-7.

5. Marchette L., Holloman F. Length of stay; significant variables. J Nurs Adm 1986; 16: $12-9$.

6. Murphy E.W. Blocked beds. Br Med J 1977; 1: 1395-6. 
7. Wijdeven C.E.F. De verkeerde bed problematiek; een onderzoek naar de omvang van de verkeerde bed problematiek en naar factoren die hierop van inwloed zijn. Maastricht: Rijksuniversiteit Limburg, 1989.

8. El Ghouat $P$. Verpleeghuispatienten in een ziekenhuisbed; een analyse van de groep patiënten die vanuit een ziekenhuis doorstroomt naar een verpleeghuis. Signet 1987; 3: $18-20$.

9. Lodder J., Bouter L.M. Toekomstige aantallen patiěnten met een cerebrovasculair accident. Ned Tijdschr Geneeskd 1992; 136: 425-8.

10. Niessen L.W., Barendregt J.J., Bonneux L., Koudstaal P.J. Stroke trends in an aging population. Stroke 1993; 24: 931-9.

11. WHO Task Force on Stroke and other Cerebrovascular Disorders. Stroke-1989: recommendations on stroke prevention, diagnosis and therapy. Stroke 1989; 20: 1407-31.

12. De intramurale gezondheidszorg in cijfers. Utrecht: Instituut voor onderzoek, informatie en opleidingen in de zorg (NZII), 1993. 
HOOFDSTUK 3

Home care-a realistic alternative for bed-blocking stroke victims in acute hospital wards?

The conceptions of caregivers in six disciplines concerned

E. Hermans, J.P.M. Dïederiks, H. Philipsen

Published in: Scandinavian Journal of Caring Sciences 1996; 10: 81-87 


\section{ABSTRACT}

Up to half of the stroke patients admitted to acute hospital wards become bed-blockers. Investigations have been carried out in an effort to identify factors related to this problem. Very little is known about options which may lead to an alleviation of this problem. We investigated to what extent, in the opinions of professional representatives of six disciplines, home care can contribute to a solution. Sixty-nine stroke patients who were actually blocking beds in an acute hospital ward were described and examined on paper by a multidisciplinary panel. These patients were all moderately to severely disabled and needed a high degree of help in activities of daily life (ADL) and household activities. Estimations of the number of patients who were judged to be suitable for home care varied, although there was a fair degree of agreement between panel members concerning those patients who could and those who certainly could not return to their homes. Concerning one-third of the patients the opinions of the caregivers diverged. Factors related to the judgement of each panel member are identified. A method for selecting patients to be substituted to lower levels of care is suggested and discussed. 


\section{INTRODUCTION}

An important aim of Dutch health policy is to realize innowations in thealth care in general and substitutions for institutionalization in particular. The line of argument is that, on the one hand, costs of institutional care are increasing, while on the other the lowest level of care possible is most favourable for the patient's well being and recovery. In the period 1990-1992 a policy was implemented by the Dutch Health Department called "Innovations in home care". One of the projects in this programme was concerned with the problem of the disproportional long duration of stay in hospital by stroke victims. This problem is well known and wide spread in general hospitals in western countries, and is usually referred to as 'bed-blocking'. It occurs when a patient who in a consultant's opinion no longer requires the services provided for a hospital bed, cannot be discharged or transferred to a more suitable accomodation (Hall \& Bytheway 1985). As has been stated by Gray (1988) the notion of bed-blocking in the first place refers to the needs of hospitals, whose resources are taken as given. Others have argued that the emergence of blockage as a problem is related to a dominant model of acute care in hospitals (Hall \& Bytheway 1985), and that the phenomenon seems inevitable in wards that are attempting to cope with the steadily increasing proportion of elderly patients according to traditional models of acute care (Coid \& Crome 1986). We use the term bed-blocker not because we wish to blame the patients for the very existence of the problem, but because it is the most current term to refer to a bed for which through put temporarily has stopped. In the Netherlands most patients in blocked-beds are waiting for nursing home placement, and a stay in a blocked-bed is inappropriate to their needs. We hypothesized that a number of these patients could be cared for more suitably at home on the condition that home care could be extended to some degree for a longer period of time, a possibility which does not exist in the Netherlands. Home care in our study was defined as all help which is given in the patient's home, or which can be attained from the patient's home, including day attendance in a nursing home or in a home for the aged. We decided to concentrate on stroke patients because the problem of bed-blocking is particularly alarming among this group (Hermans et al 1995, Lewis \& Purdie 1988, Zimmer 1974). In a recent study on data from the same project (Hermans et al 1995) we found that of all stroke patients admitted to hospital over a period of one year ( $N=232) 40 \%$ became bed-blockers. When patients with Reversible Ischaemic Neurological Deficit (RIND) and those who died in the hospital during the acute phase of their stroke were excluded, 
nearly $50 \%$ became bed-blockers. Little is known about the feasibility of home care for severe stroke patients as a substitute for institutionalization. Moreover the evidence is conflicting. A study of the effects of an organized programme of home aid services on patients discharged from a geriatric rehabilitation hospital (Nielsen et al 1972) recommended home aid service programmes to be adopted for women and for non-stroke patients. A more recent study (Zimmer et al 1985) of a home care approach for homebound and severely disabled persons (including stroke patients) showed fewer hospitalizations and nursing home admissions as well as greater satisfaction among patients and informal carers in the experimental group than in the control group. Cable \& Mayers (1985) reached the conclusion that hospitals that need to decrease their length of stay should concentrate on stroke patients. Because of the lack of information preceding the investigation, a pillot study was carried out in which a small number (seven) of stroke bed-blockers were discharged to their own homes, in order to ascertain whether the option of home care for this type of patients was worth investigating at all. These patients were to be selected by the caregivers in the hospital. The partners in the project were obliged to offer the patients all the care they needed, even if this was more than the standard amount. Several remarkable facts emerged from this phase. Initially the caregivers in the hospital repeatedly failed to select patients whom all disciplines concerned agreed were suitable for the project's aims. In this new and unusual situation they apparently did not know which factors to consider in selecting patients. All patients who were actually admitted to the pilot study were still at home by the end of the project (one year and a half after the onset of the home care). They all had the benefit of at least some kind of informal care system, attended speech-, physical- and occupational therapy in a nursing home for two or three days a week, and received an average of $22 \mathrm{~h}$ home help weekly (doing housework, laundry, cooking meals, and so on). To gather answers to the question for how many, and for which stroke bed-blockers this kind of care could serve as an alternative to institutionalization, we conducted a panel study in which a sample of stroke bed-blockers were presented to a multidisciplinary panel. The aim was to develop a method by which stroke bed-blockers who could be cared for at home can be most readily distinguished from those who could not. To achieve this aim we intended to:

1 estimate the number of stroke bed-blockers who could, according to the individual opinions of the caregivers of each discipline, potentially be cared for at home; 
2 determine the number of stroke bed-blockers about whose feasibility for home care the caregivers in the panel agreed; and

3 identify variables significantly related to the judgements of each panel member.

\section{MATERIAL AND METHODS}

The project took place in the catchment area of the Maasland Hospital (180.000 inhabitants), a large community hospital at two locations in the towns of Sittard and Geleen in the extreme south of The Netherlands. Stroke patients are admitted to two acute medical wards at the Sittard hospital site. Stroke was defined following the classification by the World Health Organization (1989). During the year 1992 all stroke bed-blockers were recorded. Those patients who had not been discharged within 10 days after the day they became bed-blockers were expected to have a serious discharge problem, and were consequently included in the study ( $N=69)$. The neurologist made the decision on whether a patient was still, or no longer in need of hospital treatment. No criteria for this decision were specified in advance. In concert with the members of the panel it was decided that the following information on these patients be recorded:

- age

- gender

- living situation

- an estimation of the quality of the relations in the patients' social network

- general data on physical and mental functioning

- specifications of the remaining need for:

- medical care

- nursing care

- ADL care

The remaining need for medical-, nursing- and ADLcare was measured using a list containing the most frequently occuring medical (max. $n=18$ ), nursing $(\mathrm{n}=17)$ and ADL $(\mathrm{n}=27)$ activities. Those activities in which the patients needed any help were scored.

Nursing care included specific nursing activities (such as administer medicine, prevention of bedsores, giving injections, and so on). Help with washing, toileting, etc. was defined as ADLcare. The analysis of the need for ADLcare was further detailed by breaking down this variable into the need for help in: 
- personal care (washing, toilet, getting into bed, getting up, etc.)

- household care (doing laundry and shopping, household chores, etc.) and

- supervision (administrative affairs, emotional support, etc.).

The general degree of physical and mental functioning was recorded on a four-point scale, varying from "no disabilities" to "total dependency". The quality of the patients' network relations was estimated on the basis of the impressions the nursing staff in the hospital had with regard to this. All data collection, registrations and scorings were performed by the nursing heads of the hospital wards on the day the patient became a bed-blocker.

Twenty-five patients were male (36\%), and 44 were female. The mean age was 76.2 years $(+/-8.3$; age range: $49-93)$. Twenty patients $(29 \%)$ had been living alone before admission; 19 (28\%) were estimated to have good network relations. Twenty-nime patients $(42 \%)$ were totally dependent both physically and mentally, while another 14 were physically, and another 2 were mentally totally dependent. The degree of need that remained for medical-, nursingand ADLcare is shown in table 1. Our multidisciplinary panel consisted of a general practitioner (hereafter called the GP), a nursing home physician (nursing home), the two nursing heads of the hospital wards (ward head 1 and ward head 2), a head community nurse (community nurse), a head of a home help agency (home help), and a head of the nursing staff in a home for the aged (home for the aged).

In the course of 1992 the 69 cases were consequently presented on paper to the individual members of the panel. In each case they were asked to score individually and without mutual contact whether they:

thought the patient could be suitably served by the kind of home care as experienced in the pilot study (home care posisible),

b thought the patient could not be served with this kind of care (home care impossible), or

c could not make up their minds because they felt that there was insufficient information available on which to base their opinion.

The agreement between the evaluations of the members of the panel was tested using Cohen's Kappa. The Kappa statistic is corrected for chance, i.e. it measures the observed agreement adjusted for the agreement that might have been achieved just by chance. According to Landis and Koch (1977) Kappa values below or equal to 0.20 indicate poor agreement, $0.21-0.40$ fair agreement, $0.41-0.60$ moderate agreement, $0.61-0.80$ substantial agreement, and above 0.80 excellent agreement. The significance of bivariate relations was tested using the Chi-squared statistic. To investigate whether the panelscores were binomially distributed we adopted a theoretical chance of $p$ 
TABLE 1. REMAINING NEED OF CARE IN THE STUDY PATIENTS

\begin{tabular}{lllccc}
\hline & $\begin{array}{l}\text { Theoretical } \\
\text { range }\end{array}$ & $\begin{array}{l}\text { Empirical } \\
\text { range }\end{array}$ & Mean & Mediar & S.D. \\
\hline medical care & $0-18$ & $0-7$ & 1.5 & 0 & 2.01 \\
nursing care & $0-17$ & $0-9$ & 3.4 & 4 & 2.11 \\
ADL care & $0-27$ & $7-27$ & 22.2 & 24 & 4.7 \\
$\begin{array}{l}\text { The need for ADL care } \\
\text { breakdown: }\end{array}$ & & & & & \\
personal care & $0-6$ & $1-6$ & 5.6 & 6 & 1.1 \\
household care & $0-15$ & $1-12$ & 10.9 & 12 & 2.7 \\
supervision & $0-6$ & $0-6$ & 5.2 & 6 & 1.7 \\
\hline
\end{tabular}

(home care impossible) $=0,67$ and $q$ (home care not impossible) $=0,33$. For multivariate analysis we made an explorative use of logistic regression analysis. The variables were dichotomized. "Age" was dichotomized at the mean. 'Living situation' was dichotomized into those living alone and all others, 'quality of the network situation' into those whose relations were estimated as good and all others, and 'physical functioning' and 'mental functioning' each into those who were totally dependent and all others. The remaining need for medical-, nursing- and ADLcare was dichotomized at the median. The dependent variable, which originally was trichotomous, was also dichotomized by combining the answer options ' $a$ ' and ' $c$ '. By doing so, we divided the study population into those for whom home care was judged to be impossible and all others.

\section{RESULTS}

\subsection{THE PANEL SCORES WITH RESPECT TO THE OPTION OF HOME CARE}

The judgements of the members of the panel with respect to home care were rather divergent, as is shown in table 2 . Considering the scores of the representatives of the three disciplines that traditionally offer home care in the Netherlands (GP, community nurse and home help) the home help proved to be the one with the highest rate of rejection. In $77 \%$ of the cases the possibility of home care was rejected at once by the home help as opposed to only $44 \%$ of the cases by the community nurse and $54 \%$ by the GP. Some members of the panel were more definite in their judgements than others, judging from the 
TABLE 2. JUDGEMENTS OF PANEL MEMBERS WITH RESPECT TO POTENTIAL HOME CARE FOR BED-BLOCKING STROKE PATIENTS $(\%)$

\begin{tabular}{llllllll}
\hline & $\begin{array}{l}\text { Home } \\
\text { help }\end{array}$ & $\begin{array}{l}\text { Community } \\
\text { nurse }\end{array}$ & $6 \mathrm{P}$ & $\begin{array}{l}\text { Home for Nursing } \\
\text { aged }\end{array}$ & $\begin{array}{l}\text { Ward } \\
\text { home }\end{array}$ & $\begin{array}{l}\text { Ward } \\
\text { head 1 }\end{array}$ & head 2 \\
\hline home care impossible & 77 & 44 & 54 & 75 & 65 & 78 & 78 \\
home care possible & 10 & 17 & 13 & 25 & 15 & 15 & 19 \\
$\begin{array}{l}\text { more information } \\
\text { wanted }\end{array}$ & 13 & 39 & 33 & - & 20 & 7 & 3 \\
\hline
\end{tabular}

percentages seeking more information. The community nurse and the GP asked for more information in $39 \%$ and $33 \%$ of the cases, while the home help only did so in $13 \%$ of the cases. The additional information the members of the panel asked for was mostly concerned with the strength of the informal support system, the possibility to attend day treatment in a nursing home, and with the suitability of the house in relation to the patients' disabilities.

\subsection{THE DEGREE OF AGREEMENT IN THE JUDGEMENTS OF THE PANEL MEMBERS}

The question arises whether the members of the panel indicated the same patients in judging whether home care was possible or not. Thus we calculated the degree of unanimity and divergence among the panel members. We also investigated whether the panelscores were binomially distributed. The data are presented in table 3 . In 22 cases (32\%) the panel members showed unanimous agreement, and in 43 cases (62\%) there appears to be almost unanimous agreement between the members of the panel, with only one panel member expressing a divergent opinion. Thus in 26 cases ( $38 \%$ ) opinions were predominantly divergent. In only five cases were all panelmembers in agreement that the option of home care should not be rejected in advance. It should be noted that this did not necessarily mean that home care was possible in their opinion. Since the variable was dichotomized, it could also be an expression of desiring more data on the patient's situation. Table 3 also reveals that the panelscores were not binomially distributed. If this had been so, in 18 cases 6 or 7 caregivers would have judged home care to be impossible, while empirically they did so in twice as many cases. Table 4 contains Cohen's Kappa for every pair of panel members. As table 4 shows, the degree of agreement between the members of the panel is rather modest, with Kappa values varying from 0.14 to 0.60 . The highest degree of agreement exists 
TABLE 3. ONERALL AGREEMENT IN JUDGEMENTS OF PANEL MEMBERS WITH RESPECT TO POTENTIAL HOME CARE FOR BED-BLOCKING STROKE PATIENTS

\begin{tabular}{lcc}
\hline $\begin{array}{l}\text { Number of panel members } \\
\text { judging tiome care impossible }\end{array}$ & \multicolumn{2}{l}{ in number of cases $(\%)$} \\
\hline 0 & $5(7)$ & $0(0)$ \\
1 & $2(3)$ & $0(0)$ \\
2 & $6(9)$ & $3(4)$ \\
3 & $8(11)$ & $9(13)$ \\
4 & $6(9)$ & $18(26)$ \\
5 & $6(9)$ & $21(30)$ \\
6 & $19(27)$ & $14(20)$ \\
7 (all) & $17(25)$ & $4(6)$ \\
\hline
\end{tabular}

$* p=0.67$

between the two ward heads, but these wardheads show limited agreement with the home caregivers in the panel. The lowest agreement exists berween ward head 1 and the community nurse. Dividing the members of the panel into two echelons of home caregivers (GP, community nurse, home help) on the one hand, and clinical caregivers on the other, it can be concluded from table 4 that most agreement is present within each of the echelons rather than between the echelons. The only panel member to break this pattern was the nursing home physician. He was -of all clinical caregivers- the one who reached the highest agreement with home caregivers (Kappa values for agreement with home help, GP and community nurse: $0.49,0.46$ and 0.36 ). The overall Kappa value was also rather modest ( 0.311$)$, but we found remarkable differences in overall Kappa values for each of the three single response categories. We found higher agreement between the members of the panel concerning which patients eventually could return to their homes (Kappa value 0.51 ) than about those who could not (Kappa value 0.35). There is vintually no agreement at all on the question of whether in any particular case more information was needed (Kappa value 0.08).

\subsection{VARIABLES SIGNIFICANTLY RELATED TO THE JUDGEMENTS OF THE PANEL MEMBERS}

In table 5 we present the relations between the independent variables and the judgements of the individual members of the panel. Table 5 reveals that all 
TABLE 4. PAIRWISE AGREEMENT BETWEEN JUDGEMENTS OF PANEL MEMBERS WTTH RESPECT TO POTENTIAL HOME CARE FOR BED-BLOCKING STROKE PATIENTS (Cohen's Kappa)

\begin{tabular}{|c|c|c|c|c|c|c|c|}
\hline & $\begin{array}{l}\text { Home } \\
\text { help }\end{array}$ & $\begin{array}{l}\text { Community } \\
\text { nurse }\end{array}$ & GP & $\begin{array}{l}\text { Ward } \\
\text { head } 1\end{array}$ & $\begin{array}{l}\text { Ward } \\
\text { head } 2\end{array}$ & $\begin{array}{l}\text { Nursing } \\
\text { home }\end{array}$ & $\begin{array}{l}\text { Home for } \\
\text { aged }\end{array}$ \\
\hline Home help & $x$ & & & & & & \\
\hline Community nurse & 0.32 & $x$ & & & & & \\
\hline GP & 0.48 & 0.27 & $x$ & & & & \\
\hline Ward head 1 & 0.19 & 0.14 & 0.19 & $x$ & & & \\
\hline Ward head 2 & 0.31 & 0.22 & 0.36 & 0.60 & $x$ & & \\
\hline Nursing home & 0.49 & 0.36 & 0.46 & 0.33 & 0.40 & $x$ & \\
\hline Home for aged & 0.30 & 0.14 & 0.25 & 0.38 & 0.48 & 0.32 & $x$ \\
\hline
\end{tabular}

members of the panel considered the degree of dependency and the degree in which patients needed care as highly significant factors in judging whether home care is possible or impossible. If the need for ADLcare is subdivided it is striking that of the four institutional caregivers only the judgement of wardhead 2 is significantly related to the patients' need for help in household activities. Table 5 also shows that the significance of demographic factors for home care is less obvious than is the case with the care- and dependency-related variables. All panel members, with the exception of the community nurse, judged women more suitable to be cared for at home than men, but gender was only significantly related to the judgements of the GP and the nursing home playsician. The patients' living situation was not related to the judgements of the home help, the GP, the home for the aged and wardhead 2 in any way. The community nurse, the nursing home physician and wardhead 1 judged home care less appropriate for people who were living alone compared to those who were living with someone else, but this distinction only reached statistical significance for the community nurse. Regarding the importance of the patients' network relations with respect to home care, only the three home caregivers in our panel made a distinction in favour of those patients with good network relations, though the community nurse's opinion just failed to reach statistical significancy. No statistical significant relation was found between age and the judgements, although the judgements of the home help and the home for the aged tended to be in favour of the older age group. Finally we built seven regression equations with the judgements of the respective panellists as the dependent variables. As independent variables we included into the equations only those variables which 
TABLE 5. VARIABLES RELATED TO POTENTIAL HOME CARE FOR BED-BLOCKING STROKE PATIENTS

\begin{tabular}{|c|c|c|c|c|c|c|c|}
\hline & Home help & $\begin{array}{l}\text { Community } \\
\text { nurse }\end{array}$ & GP & $\begin{array}{l}\text { Home } \\
\text { for aged }\end{array}$ & $\begin{array}{l}\text { Nursing } \\
\text { home }\end{array}$ & $\begin{array}{l}\text { Ward } \\
\text { head } 1\end{array}$ & $\begin{array}{l}\text { Ward } \\
\text { head } 2\end{array}$ \\
\hline Gender Women & & & * & & $*$ & & \\
\hline Living situation & & * & & & & & \\
\hline \multicolumn{8}{|l|}{ Not alone } \\
\hline Network relations & * & & * & & & & \\
\hline Good & & & & & & & \\
\hline Physical dependency & * & & * & * & * & * & $*$ \\
\hline Not totally dependent & & & & & & & \\
\hline Mental dependency & $*$ & & * & * & * & & $*$ \\
\hline Not totally dependent & & & & & & & \\
\hline $\begin{array}{l}\text { Need for medical care } \\
<\text { median }\end{array}$ & * & $*$ & * & & $*$ & * & * \\
\hline $\begin{array}{l}\text { Need for nursing care } \\
<\text { median }\end{array}$ & * & * & * & * & * & & * \\
\hline $\begin{array}{l}\text { Need for ADL care. } \\
<\text { median }\end{array}$ & * & $*$ & $*$ & * & $*$ & & * \\
\hline $\begin{array}{l}\text { The need for ADLcare } \\
\text { breakdown: }\end{array}$ & & & & & & & \\
\hline $\begin{array}{l}\text { Need for personal care } \\
<\text { median }\end{array}$ & $*$ & * & * & * & $*$ & * & $*$ \\
\hline $\begin{array}{l}\text { Need for household care } \\
\text { < median }\end{array}$ & * & & * & & & & * \\
\hline $\begin{array}{l}\text { Need for supervision } \\
<\text { median }\end{array}$ & * & * & $*$ & $*$ & * & & \\
\hline
\end{tabular}

were bivariately related to the judgement of the panel member concerned. The results are shown in table 6 , which shows that the judgement of five panellists was significantly influenced by only one independent variable. The GP's judgement was most complex since it was determined by three variables. Only home caregivers emphasize the importance of ADLcare in their judgements. The nursing home physician and the home help particularly seem to stress the importance of their own disciplines as a criterion for home care. In three cases the patients' physical dependency was a significant variable, while mental dependency, the need for medical care, age and network 
TABLE 6. SIGNIFICANT DETERMINANTS (LOGISTIC REGRESSION ANALYSTS) OF POTENTIAL HOME CARE FOR BEDBLOCKING STROKE PATIENTS (B VaLUES)

\begin{tabular}{|c|c|c|c|c|c|c|c|}
\hline & $\begin{array}{l}\text { Home } \\
\text { help }\end{array}$ & $\begin{array}{l}\text { Community } \\
\text { numse }\end{array}$ & GP & $\begin{array}{l}\text { Home for } \\
\text { aged }\end{array}$ & $\begin{array}{l}\text { Nursing } \\
\text { home }\end{array}$ & $\begin{array}{l}\text { Ward } \\
\text { head } 1\end{array}$ & $\begin{array}{l}\text { Ward } \\
\text { head } 2\end{array}$ \\
\hline Gender & & & $2.97 * *$ & & & & \\
\hline \multicolumn{8}{|l|}{ Women } \\
\hline Living situation & & $1.49^{*}$ & & & & & \\
\hline \multicolumn{8}{|l|}{ Not alone } \\
\hline Network relations: & & & $0.87 *$ & $0.92 * *$ & & & $0.86^{*}$ \\
\hline \multicolumn{8}{|l|}{ Good } \\
\hline Physical dependency & & & & & $1.29^{*}$ & & \\
\hline \multicolumn{8}{|l|}{ Wot totally dependent } \\
\hline $\begin{array}{l}\text { Need for nursing care } \\
<\text { median }\end{array}$ & $2.14^{*}$ & & $1.67 *$ & & & & \\
\hline
\end{tabular}

relations were no independent determinants for the judgement of any of the panel members.

\section{DISCUSSION}

Our study was concerned with the question of whether extended home care can serve as a substitute for bed-blocking by stroke patients in general hospital wards. The outcome suggests that for a fair number of patients this might be a realistic prospect.

Concerning the method we used it must be stated that, although the trial was anonymous, the nursing heads in the hospital may have recognized some of the patients. This did not cause any bias because they, as well as the other panel members, only knew that under the present system these patients could not be discharged back to their homes. About the experimental situation on which their opinion was investigated (i.e. extended home care for bed blocking stroke patients) they also had equal knowledge; they all knew that in a pilot study for a limited number of patients this turned out to be a realistic possibility. With respect to the number of patients potentially taken into account for this kind of care, conclusions must be drawn with caution because the members of our panel varied widely in their estimations, with 
percentages varying from 23 to $56 \%$. By far the home help showed the most negative attitude towards the possibility of home care for this type of patient. This is understandable, because in the Netherlands waiting lists for home help do already exist. Moreover, in the pilot phase of the project it became apparent that the home help represented the discipline that would be supplying the largest contribution if home care for stroke bed-blockers were to be implemented. Nevertheless, the caregivers in our panel unanimously agreed in $32 \%$ of the cases, or almost unanimously (with at most one member expressing a divergent view) in $62 \%$ of all cases. Obviously those patients who certainly can, and those who certainly cannot be cared for at home are not very difficult to distinguish. This distinction therefore can be accomplished by one or two professionals, regardless of function. Concerning the remaining $38 \%$ of the patients opinions in the panel were divided; a division which seems to run parallel with health care echelons. Only home caregivers actually paid attention to the presence of some kind of informal support system, the quality of the relations in this system, and the patients" ability to perform some personal ADL and household activities. It is striking that clinical caregivers, who in our trial were the ones to provide information, in more than half of the cases had no clear impression of the patients' network situation. The fact that of clinical caregivers only the judgement of the nursing home physician showed a fair degree of agreement with home caregivers is far from surprising. Nursing home physicians are closely concerned with long-term care for geriatric patients, and consequently they usually have a thorough impression of the possibilities of family and community support. Attention should be paid in this connection to the relatively high scores of the community nurse and the GP in the panel indicating the lack of essential information on which to base their judgements. This poses the question of who should provide what information at what time. Knowledge about the patients' social situation has to be improved in order to optimalize through-put of patients to their homes. The fact that the home help less often asked for more information than the other panel members did, shows that the information which was actually given, was sufficient for the representative of the home help to develop a predominantly negative attitude towards home care. This is probably caused by the fact that these patients turn out to have a need for ADLcare (including both personal care and household help) to such a degree that, if they were to be cared for at home, home help agencies would run into capacity problems. Our results indicate that home caregivers should be strongly involved in the decision whether stroke patients can be cared for at home or not. Therefore we wish to underline the suggestion put 
forward earlier to establish interfaces between community- and hospital-based service systems for the elderly (Netting \& Williams 1989). In such an interface the appropriate level and continuity of care can be discussed for the remaining one-third of the stroke bed-blockers about whom the opinions initially seemed to be divided. Both clinical and home caregivers should be represented in this interface. It is for reasons of efficiency that we suggest to select for this task those professionals who show a high degree of agreement with professionals from other disciplines and echelons; for instance a nursing home physician, a general practitioner and a home help caregiver. Using this method a justifiable way of substituting stroke bed-blockers may be started, but it is still questionable whether home care for these patients in the long run will prove to be a practical option. Since an increase of the number of first stroke cases due to the ageing of the population may be expected, further investigations concerning the feasibility of home care for stroke bed-blockers must be encouraged. Studies should not only include the benefits for the health care system and patients, but should also take into account the cost to the informal caregiver (Haug 1985).

\section{REFERENCES}

1. Hall D. \& Bytheway B. The blocked bed; definition of a problem. Soc Sci Med 1985; 16, 1985-91.

2. Gray B. The blocked bed (Letter). NZ Med J 1988; 101,672.

3. Coid J. \& Crome P. Bed blocking in Bromley. Br. Med J 1986; 292: 1253-6.

4. Hermans E., Anten H.W.M., Diederiks J.P.M., Plilipsen H., Beeren H.W.J.M. Patiëntkenmerken met voorspellende betekenis voor 'verkeerde-bedproblematiek' op de neurologische afdeling van een algemeen ziekenhuis. Ned Tijdschr Geneeskd 1995; $139,890-4$.

5. Lewis H. \& Purdie G. "The blocked bed; a prospective study. NZMed J1988;, 101, 575-6.

6. Zimmer, J.G. Length of stay and hospital bed misutilization. Medical Care 1974; 12 , $453-62$.

7. Nielsen M., Blenkner M., Bloom M., Downs T., Beggs H. Older patients after hospitalization: a controlled study of a home care service. Am J Publ Health 1972;62, 1094-101.

8. Zimmer J.G., Groth-Juncker A., McCusker J. A randomized controlled study of a home health care team. Am J Publ Health 1985; 75, 134-41.

9. Cable E.P. \& Mayers S.P. Discharge planning effect on length of hospital stay. Arch Phys Med Rehabil 1985; 64, 57-60. 
10. WHO Task Force on Stroke and other Cerebrovascular Disorders. Recommendations on stroke prevention, diagnosis, and therapy. Stroke 1989; 20, 1407-31.

11. Landis J.R., Koch G.G. The measurement of observer aygreement for categorical data. Biometrics 1977; 33, 159-74.

12. Netting F.E. \& Williams F.G. Establishing interfaces between community= and hospital-based service systems for the elderly. Health Soc Work $1989 ; 14,134-9$.

13. Haug M.R. Home care for the ill elderly - Who benefits? Am I Publ Health $1985 ; 75$, $127 \times 8$. 
HOOFDSTUK 4

\section{CVA-patiënten in het verkeerde bed}

Een onderzoek naar theoretische alternatieven

E. Hermans, H.W.M. Anten, J.P.M. Diederiks, H. Philipsen, B. Hameleers, A. Schepers, 0. Sikkes-Mekel

Gepubliceerd in: Tijdschrift voor Sociale Gezondheidszorg 1996; 74: 96-100 


\section{SAMEN VATTING}

Onder patiënten die in het ziekenhuis in het verkeerde bed liggen, zijn veel patiënten met een CVA. Het aantal eerste CVA-gevallen zal door de vergrijzing toenemen. Een panel van zorgverleners onderzocht voor 69 CVA-patiënten in het verkeerde bed de mogelijkheden tot, en voorwaarden voor substitutie naar huis of naar een verzorgingshuis. Het panel oordeelde dat 28 van deze 69 patiënten ontslagen zouden kunnen worden naar huis of naar een verzorgingshuis indien aan bepaalde voorwaarden voldaan zou kunnen worden. In werkelijkheid gingen slechts 8 van deze patiënten naar huis, en geen enkele naar een verzorgingshuis. De overigen gingen naar een verpleeghuis $(n=51)$, een revalidatiecentrum $(n=3)$, of overleden in het verkeerde bed $(n=7)$. Substitutie naar het verzorgingshuis stuitte volgens het panel op de minste problemen in de voorwaardelijke sfeer. Om substitutie naar huis mogelijk te maken waren de voornaamste voorwaarden: beschikbaarheid van voldoende dagbehandelingscapaciteit in het verpleeghuis en inzet van bovenreguliere thuisverzorging.

\section{ABSTRACT}

Substitution of institutional care to home care or care in a home for the elderly is an important aim of Dutch health policy. We have investigated the theoretical possiblities of substitution for bed-blocking stroke patients in a Dutch general hospital. Sixty-nine patients were described and presented on paper to a multidisciplinary panel of caregivers. The panel judged that under certain conditions 28 of them could be substituted to their homes or to a home for the elderly. Only 8 of these patients actually returned home, and none were placed in a home for the elderly. Additional conditions to realize this possible substitution seerned to be minimal in homes for the elderly. Substitution to home care seemed to be much more difficult to realize. To this end, according to the opinion of our panel, especially the availability of home help and day attendance in a nursing home should be enlarged. The results of this investigation may help to realize the policy of substitution. 


\section{INTRODUCTIE EN VRAAGSTELLING}

De Commissie Modernisering Ouderenzorg (1994) constateert dat het mogelijk is orn substantiële verschuivingen te realiseren in de keten verpleeghuis-verzorgingshuis-thuissituatie.

In het onderhavige onderzoek, dat deel uitmaakt van een breder project onder CVA-patiënten in het verkeerde bed, staat de vraag centraal in hoeverre thuiszorg of zorg in het verzorgingshuis zou kunnen bijdragen aan een oplossing voor de verkeerde-bedproblematiek onder CVA-patiënten in het algemeen ziekenhuis. Van een verkeerd bed is sprake wanneer een patiënt medisch-specialistisch uitbehandeld is, maar om enigerlei reden niet kan worden ontslagen. Doorgaans wordt dan een verpleeghuisindicatie aangevraagd (Fahrenfort \& Koning 1994). CVA-patiënten vormen, zowel in Nederland als daarbuiten, de diagnosegroep waarbinnen het verkeerde-bedprobleem zich met name voordoet. Een recente studie laat zien dat $47 \%$ van alle in een ziekenhuis opgenomen CVA-patiënten die de acute fase overleven in het verkeerde bed terecht komt. Van alle verkeerde-bedpatiënten op de neurologische afdeling had $86 \%$ een CVA-diagnose (Hermans 1995). Andere studies wijzen in dezelfde richting (Wijdeven 1989, Coid \& Crome 1986, Lewis \& Purdie 1988, Marchette \& Holloman 1986, Maguire et al 1986, Zimmer 1974).

De problematiek is actueel omdat het aantal eerste CVA-gevallen onder invloed van de vergrijzing zal gaan toenemen (NWO 1992). Verwacht mag worden dat daarmee ook de verkeerde-bedproblematiek onder deze patiënten zal toenemen. Uit een kleinschalig experiment in het kader van het project waarvan ook dit onderzoek deel uitmaakt bleek dat thuiszorg voor een aantal van deze patiënten in principe een haalbaar alternatief kan vormen (Hermans 1992). Niet duidelijk is voor hoeveel en voor welke patiënten deze conclusie geldt. Onderzoek naar deze mogelijkheden is slechts beperkt beschikbaar, gedateerd en afkomstig uit het buitenland (Nielsen et al 1972, Zimmer et al 1985, Cable \& Mayers 1983). Om een indruk te krijgen van de substitutiemogelijkheden voor CVA-patiënten in het verkeerde bed, en van de voorwaarden waaronder deze gerealiseerd kunnen worden, hebben wij een panelonderzoek opgezet met de volgende vraagstelling:

1 In welke mate kunnen CVA-patiënten in het verkeerde bed volgens een multidisciplinair panel in theorie naar huis of naar een verzorgingshuis worden ontslagen?

2 Hoe verhoudt dit theoretisch mogelijke ontslagpatroon zich tot het werkelijke ontslagpatroon? 
3 Onder welke voorwaarden kunnen volgens het panel de potentieel aamwezige substitutiemogelijkheden worden gerealiseerd?

4. Welke kenmerken bepalen het onderscheid tussen verkeerde-bedpatiënten die naar huls of naar een verzorgingshuis ontslagen worden en patiënten voor wie substitutie naar een van deze bestemmingen wel, respectievelijk niet mogelijk wordt geacht?

\section{PATIËTTEN EN METHODE}

Het onderzoek bestreek het gehele kalenderjaar 1992, en is uitgevoerd op 2 (van de 3) neurologie-afidelingen van het Maaslandziekenhuis Sittard-Geleen waar in de loop van het onderzoeksjaar alle opnamen wegens CVA zijn geconcentreerd. Ter bepaling van een CVA werd de WHO-definitie gehanteerd (1989). De ingang van de verkeerde-bedperiode werd door de neuroloog vast gesteld. Criteria hiervoor waren niet vooraf gespecificeerd. Alle verkeer de-bedpatiënten met een CVA die 10 dagen na de verkeerde-boekdatum nog niet waren ontslagen, werden geregistreerd $(\mathrm{N}=69)$. Deze termijn werd ingebouwd omdat patiënten die 10 dagen na de verkeerde-beddatum nog niet ontslagen waren, geach werden een ernstig ontslagprobleem te kennen. Elke patiënt werd door de neuroloog en het verpleegkundig hoofd van de afdeling beschreven naar: leeftijd, geslacht, woonsituatie, algemene lichamelijke en psychische toestand ( 4 punts-schaal), resterende zorgbehoefte, en de kwaliteit van de relaties in het sociale netwerk. De beschrijvingen waren gebaseerd op de toestand van de patiënten op het moment van specialistische uitbehandeling. De resterende zorgbehoefte werd door het verpleegkundig afdelingshoofd geinventariseerd op een checklist met de meest voorkomende verpleegkundige, medische, en verzorgende functies (in totaal resp. 17, 18 en 27 functies). Deze zijn weergegeven in overzicht I. Elke functie waarbij de patiènt hulp nodig had, cq. niet zelfstandig kon uitvoeren werd gescoord.

De relationele situatie van de patiënt werd gescoord op basis van de indruk die de zorgverleners in het ziekenhuis hiervan hadden op basis van kontakten met de patiënt en diens relaties. Wij vroegen aan een vast panel van zorgverle ners om op basis van deze informatie voor alle 69 patiënten te beoordelen of zij naar hun mening thuis of in het verzorgingshuis verzorgd zouden kunnen worden als alternatief voor het verkeerde bed (substitutie). Het panel bestond uit een huisarts, een zorghoofd van een instelling voor gezinsverzorging, een hoofdwijkverpleegkundige, en een hoofd verzorging van een 
VERZICHTI. CHECKLIST VERPLEEGKUNDIGE, MEDISCHE EN VERZORGENDE FUNCTIES

\begin{tabular}{|c|c|c|}
\hline Verpleegkundige functies & Medische functies & Verzorgende functies \\
\hline Infusie/bloedtransfusie & Bloedsuiker bepalen & Ontbijt/lunch klaarmaken \\
\hline verwijderen & Zuurstof toedienen & Koken \\
\hline Medicijnen oraal & Blaasspoelen & Dagelijkse boodschappen \\
\hline Medicijnen rectaal/waginaal & Rectumcanule inbrengen & Periodieke boodschappen \\
\hline Dog-, oor-, neusdruppelen & Stoma spoelen & Plànten, huisdieren verzorgen \\
\hline Huid zalwen & Wondtampons verwijderen & Kinderen verzorgen \\
\hline Wondverzorging & Clysma geven & Kinderen opvoeden "begeleiden \\
\hline Decubituswerzorging & Injecties toedienen & Lichaamsverzorging \\
\hline Stomaverzorging & Tracheacanule verzorgen & Aan-, witkleden \\
\hline Manueel ontlasting verwijderen & Supra-pubische catheter & In, utit bed \\
\hline Stompverzorging & Hechtingen, agraves, drains & Lopen, bewegen in/ rond huis \\
\hline Druk-, steunverband aanleggen & verwijderen. & Toiletgang \\
\hline Controle bewegingsapparaat & & Eten \\
\hline Controle lengte, gewnicht: & & Bed opmaken/verschonen \\
\hline Controle temp, pols, ademhaling & & Toericht medicijngebruik \\
\hline Controle sputum, faeces, urine & & Reactiveren/vaardigheden \\
\hline Controle vochthuishouding & & uitbreiden \\
\hline \multirow[t]{5}{*}{ Insuline injecties } & & Financiële en adm. zaken \\
\hline & & Sfeer scheppen/gastwrouwrol \\
\hline & & Observeren, Luisterem \\
\hline & & Struktuur scheppen, toezicht \\
\hline & & houden \\
\hline
\end{tabular}

verzorgingshuis. In gevallen waarin het panel het huidige zorgaanbod van thuiszorg of verzorgingshuis daartoe niet toereikend achtte, werd gevraagd aan welke voorwaarden volgens het panel voldaan moest worden om de potentiële substitutiemogelijkheden te realiseren. Patiënten waren vooraf geanonimiseerd. De activiteit van het panel vond volledig gescheiden plaats van de werkelijke ontslagprocedure, en heeft hierop geen enkele invloed gehad.

Ten behoeve van de analyse zijn de variabelen die de resterende zorgbehoefte weergeven gedichotomiseerd op de mediaan. Ter verfijning van de analyses is de variabele 'verzorgingsbehoefte' uitgesplitst in 'ADL-behoefte' 
(Algemene Dagelijkse Levensverrichtingen), 'HDL-behoefte' (Huishoudelijke Dagelijkse Levensverrichtingen) en 'Begeleidingsbehoefte' (toezicht, psychische steun, observatie, e.d.). Ook deze zijn gedichotomiseerd op de mediaan. Ten aanzien van de kwaliteit van de relaties deed zich het probleem voor dat men in het ziekenhuis in zeer veel gevallen geen informatie hierover had. Wij hebben daarom gedichotomiseerd in 'goed' versus 'matig/slecht/onbekend'. Dit lijkt verdedigbaar omdat het waarschijnlijk is dat goede netwerkrelaties bij twijfel omtrent thuisplaatsing de beslissing ten gunste van thuisplaatsing zullen beïnvloeden. Bij matige, slechte of onbekende relaties zal het risico daarentegen al snel te groot worden gevonden, en de patiënt voor het verpleeghuis worden aangemeld. Toetsen op lineaire trends zijn met eenweg-variantieanalyse uitgevoerd op de gehele ranges van scores. De resultaten zijn in tabel 3 om redenen van descriptieve elegantie gepresenteerd met gedichotomiseerde waarden. Onderlinge groepsverschillen zijn getoetst met Tukey's honestly significant difference test.

\section{RESULTATEN}

\subsection{KENMERKEN VAN DE ONDERZOEKSGROEP}

De onderzoeksgroep bestond uit 25 mannen ( $36 \%$ ) en 44 vrouwen. De gemiddelde leeftijd was 76 jaar (range: 49-93; mannen: 73 ; vrouwen: 78). Zevenenvijftig ( $83 \%$ ) patiënten waren afkomstig uit de thuissituatie; 20 (35\%) hiervan woonden thuis alleen. Vier patiënten $(6 \%)$ woonden voor hun ziekenhuisopname in een aanleunwoning, $7(10 \%)$ in een verzorgingshuis en $1(1 \%)$ in een gezinsvervangend tehuis. Achtenvifftig patiënten beschikten over enige vorm van familienetwerk. Van $19(28 \%)$ werd de relationele situatie als goed, en van 7 ( $12 \%$ ) als matig tot slecht ingeschat. Bij 32 patiënten ( $55 \%)$ had men in het ziekenhuis geen indruk van de netwerkrelaties van de patiènt. In lichamelijk opzicht was $62 \%$, en in psychisch opzicht $31 \%$ van de patiënten totaal athankelijk. De medische zorgbehoefte, verplegings- en verzorgingsbehoefte van de patiènten zijn weergegeven in tabel 1 .

Uit tabel 1 blijkt dat de patiënten met name een zeer grote verzorgingsbehoefte hadden. Op elk van de 3 onderdelen (ADL, HDL en begeleiding) was de hulpbehoefte zeer hoog. De behoefte aan medische zorg en verpleging lag aanmerkelijk lager. 
TABEL 1. DE ONDERZOEKSPOPULATIE NAAR RESTERENDE ZORGBEHOEFTE BIJ SPECIALISTISCHE UITBEHANOELING

\begin{tabular}{lllrrl} 
Variabele & \multicolumn{2}{l}{$\begin{array}{l}\text { Theoretische Empirische } \\
\text { range }\end{array}$} & $\begin{array}{l}\text { Gemiddelde } \\
\text { range }\end{array}$ & Mediaan & 5.D. \\
\hline Medische zorgbehoefte & $0-18$ & $0-7$ & 1,5 & 0 & 2,0 \\
Verplegingsbehoefte & $0-17$ & $0-9$ & 3,4 & 4 & 2,1 \\
Verzorgingsbehoefte & $0-27$ & $7-27$ & 22,2 & 24 & 4,7 \\
ADL-behoefte & $0-6$ & $1-6$ & 5,6 & 6 & 1,1 \\
HDL-behoefte & $0-15$ & $1-12$ & 10,9 & 12 & 2,7 \\
Begeleidingsbehoefte & $0-6$ & $0-6$ & 5,2 & 6 & 1,7 \\
\hline
\end{tabular}

\subsection{HET PANELOORDEEL EN HET WERKELIJKE ONTSLAG PATROON}

Het panel oordeelde dat voor 28 van de 69 verkeerde-bedpatiënten (41\%) thuiszorg of zorg in het verzorgingshuis mogelijk was. In werkelijkheid werden slechts 8 patiënten alsnog naar huis ontslagen; geen enkele werd naar het verzorgingshuis ontslagen. Zeven patiënten overleden in het verkeerde bed, drie gingen naar een revalidatiecentrum en de overige 51 gingen naar een verpleeghuis. Wanneer de werkelijke ontslagbestemming en de ontslagbestemming die volgens het panel mogelijk was tegen elkaar worden afgezet, ontstaat het beeld dat is weergegeven in tabel 2 .

Uit tabel 2 blijkt dat in de huidige situatie 61 patiënten niet naar huis of verzorgingshuis worden ontslagen. Bij een hierop gericht substitutiebeleid zouden er van deze 61 volgens het panel -onder nadere voorwaarden- maximaal $21(34 \%)$ wellicht wel naar een van deze bestemmingen ontslagen kunnen worden.

TABEL 2. DE ONDERZOEKSPOPULATIE NAAR PANELOORDEEL EN ONTSLAG-BESTEMMING UIT HET ZIEKENHUIS

\begin{tabular}{|c|c|c|c|}
\hline & PANEL-OORDEEL & & \\
\hline ONTSLAGWIJZE & $\begin{array}{l}\text { Wel substitutie- } \\
\text { mogelijkheden naar } \\
\text { huis of verzorgingshuis }\end{array}$ & $\begin{array}{l}\text { Geen substitutie- } \\
\text { mogelijkheden naar } \\
\text { huis of verzorgingshuiss }\end{array}$ & TOTAAL \\
\hline $\begin{array}{l}\text { Wel naar huis of } \\
\text { verzorgingshuis ontslagen" }\end{array}$ & 7 & 1 & 8 \\
\hline $\begin{array}{l}\text { Niet naar huis of } \\
\text { verzorgingshuis ontslagen } \\
\text { TOTAAL }\end{array}$ & $\begin{array}{l}21 \\
28\end{array}$ & $\begin{array}{l}40 \\
41\end{array}$ & $\begin{array}{l}61 \\
69\end{array}$ \\
\hline
\end{tabular}

${ }^{1}$ In werkelijkheid werden deze 8 patienten allen naar huis ontslagen. 


\subsection{VOORWAARDEN OM SUBSTITUTIE DAADWERKELIJK TE REALISEREN}

In de gevallen waarin substitutie mogelijk werd geacht, hebben wij het panel gevraagd de voorwaarden aan te geven om deze theoretische mogelijkheden te realiseren. Wat de substitutie naar het verzorgingshuis betreft lag dit vrij ongecompliceerd. In slechts een enkel geval waarin substitutie naar het verzorgingshuis mogelijk werd geacht, was volgens het panel meer dan reguliere inzet van verzorgend personeel noodzakelijk. Verplaatsing van zorg naar huis leverde meer problemen op. In totaal werden 5 vereisten genoemd om dit mogelijk te maken: dagbehandeling in een verpleeghuis (in $72 \%$ van de gevallen), bovenreguliere verzorging (72\%) en verpleging (33\%), oppasfunctie ( $22 \%$ ), en de mogelijkheid van toepassing van sondevoeding door de wijkverpleging (11\%). Meestal waren combinaties van deze voorwaarden noodzakelijk. In geen enkel geval waren alle vijf de voorwaarden nodig. In 5 gevallen ( $28 \%$ ) waren 3 of 4 voorwaarden van toepassing, en in 13 gevallen $(72 \%)$ werden 1 of 2 van de extra voorwaarden gesteld.

\subsection{ONDERSCHEIDENDE KENMERKEN TUSSEN DE UITSTROOMCATEGORIEËN}

Uit de vergelijking van het werkelijke ontslagpatroon met de panelbeoordeling komen drie groepen naar voren:

- Patiënten voor wie het panel mogelijkheden zag om thuis of in het verzorgingshuis verzorgd te worden, en die ook daadwerkelijk naar een van deze bestemmingen ontslagen werden (de "thuisgroep") $(n=7)$.

- Patienten voor wie het panel mogelijkheden zag tot verzorging thuis of in het verzorgingshuis, maar die in werkelijkheid noch naar huis noch naar het verzorgingshuils ontslagen werden (de 'substitutiegroep') $(n=21)$.

- Patienten voor wie het panel geen mogelijkheden zag tot verzorging thuis of in het verzorgingshuis, an die in werkelijkheid ook niet naar een van deze beide bestemmingen ontslagen werden (de 'niet-substitutiegroep') ( $n=40)$. Om de zinvolheid van dit groepen-onderscheid te testen hebben wij via een toets op lineariteit deze groepen met elkaar vergeleken op de verschillende onderzoeksvariabelen. De statistisch significante trends zijn weergegeven in tabel 3 .

Ten aanzien van alle in tabel 3 opgenomen variabelen blijkt dat van de thuisgroep" steeds alle patiënten, dan wel de grote meerderheid in de categorie vallen die het minste onvermogen en de laagste zorgbehoefte kent, en waarvan de netwerkrelaties goed zijn. In de 'niet-substitutiegroep' is de situatie omgekeerd: de meerderheid van de patiënten valt hier steeds in de rela- 
tief ongunstige categorie (relatief grote zorgbehoefte en onvermogen, slechte of onbekende netwerkrelaties). De 'substitutiegroep' neemt steeds de tussenpositie in. Ten aanzien van alle variabelen verschilden de gemiddelde scores van de 'thuisgroep' en de 'niet-substitutiegroep" significant van elkaar. Ten aanzien van de verzorgingsbehoefte en de variabelen die het onvermogen meten verschilden ook de gemiddelden van de 'substituticgroep' en de 'niet-substitutiegroep" significant van elkaar. Het zijn vooral zorg-en afhankelijkheidsvariabelen die het groepen-onderscheid bepalen. Sociaal-demografische variabelen leverden geen bijdrage hieraan. Dit gold ook voor de verplegingsbehoefte en de ADL-zorgbehoefte; de eerste was in alle groepen laag, de laatste in alle groepen zeer hoog. Ook de kwaliteil van de relaties leverde bij de gehanteerde dichotomisering een significant verschil op. Dit verschil verdween bij alle andere dichotomiseringen, ook indien de categorie 'onbekend' uit de analyses werd gehouden.

\section{DISCUSSIE}

Van 69 CVA-patiënten in het verkeerde bed konden er volgens een multidisciplinair panel theoretisch 28 thuis of in een verzorgingshuis worden verzorgd. In werkelijkheid werden slechts 8 van deze patiënten naar een van deze bestemmingen ontslagen. De overige 61 werden -volgens de huidige "standaard' terecht- niet naar huis of verzorgingshuis ontslagen. Volgens het panel is onder deze groep -onder voorwaarden- een maximaal substitutiepercentage van $34 \%$ haalbaar. Aangezien de onderzoeksgroep zonder nadere specificatie is vastgesteld door de neuroloog is enige voorzichtigheid op zijn plaats ten aanzien van de interpretatie van dit resultaat. Ook eerder onderzoek toonde reeds aan dat thuiszorg voor ouderen met een grote zorgbehoefte en een verpleeghuisindicatie in principe mogelijk is (Bisscheroux \& Frederiks 1986, Knapen et al 1988). Het onderscheid tussen de groepen die uit ons onderzoek naar voren komen hangt significant samen met zorggebonden variabelen en met de mate van afhankelijkheid. Dat een ernstige vorm van psychische onbekwaamheid een slechte prognostische factor is voor terugkeer naar de thuissituatie werd reeds eerder door diverse auteurs aangetoond (Fields et al 1986, Rubin \& Davies 1975, Adams \& Hurwitz 1983, Kotila et al 1977, Dijkstra et al 1995). Voorts blijken goede netwerkrelaties bij te dragen aan de substitutiemogelijkheden. In dit verband is de bevinding van belang dat men in het ziekenhuis bij meer dan de helft van de patiënten hiervan geen duidelijke indruk had. In het ziekenhuis moet hieraan dan ook zeker meer 


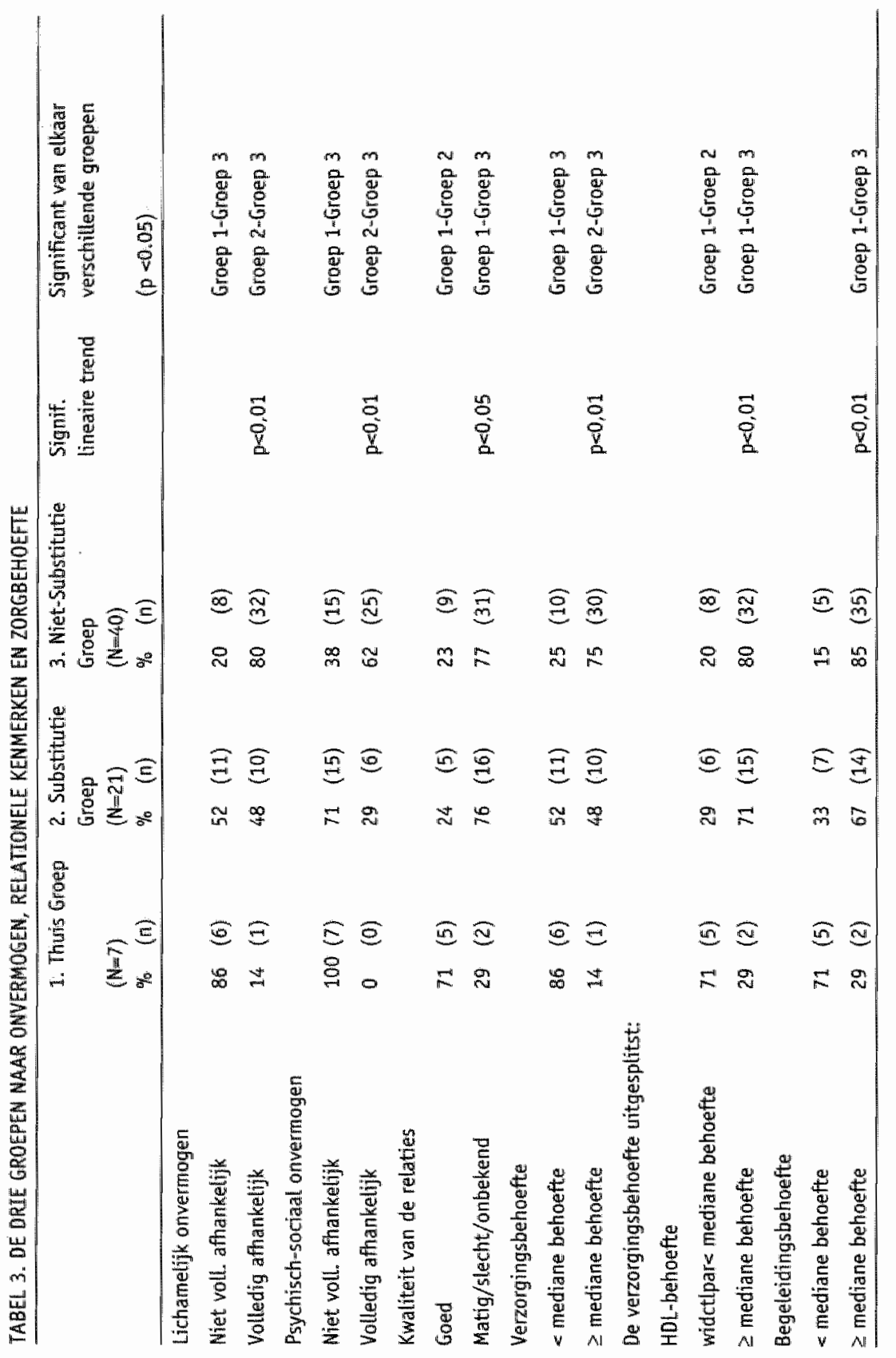


aandacht besteed worden. Substitutie naar het verzorgingshuis stuit volgens het panel op minder problemen dan substitutie naar de thuiszorg. Ook anderen kwamen tot de conclusie dat verpleeghuisgeindiceerden met intensieve zorg in het verzorgingshuis geholpen kunnen worden (Dijkstra et al 1995). Des te opvallender is het dat geen enkele verkeerde-bedpatiênt naar het verzorgingshuis werd ontslagen. Er moet dan ook rekening worden gehouden met de kans dat het panel de mogelijkheden van het verzorgingshuis in deze heeft overschat, mede door gebrek aan ervaring op dit gebied in het verzorgingshuis. De thuiszorg die deze ervaring wel heeft is veel kritischer over de substitutiemogelijkheden. Om substitutie naar de thuiszorg mogelijk te maken, is volgens het panel de realisatie van een aantal vereisten, zoals dagbehandeling in een verpleeghuis en extra verzorging en verpleging thuis een 'conditio sine qua non'. Niet bekend is hoelang de vereiste meerzorg moet voortduren. Onze ervaring uit het in de Introductie genoemde experiment wijst uit dat 1,5 à 2 jaar na aanvang van de thuiszorg gemiddeld nog steeds 2 dagen dagbehandeling per week en een forse bovenreguliere zorginzet van de gezinsverzorging noodzakelijk waren (Hermans 1992). Het feit dat na deze periode het merendeel van de patiënten nog steeds thuis verbleef, betekent dat deze vorm van zorgverlening niet alleen een substitutiemogelijkheid voor het verkeerde bed, maar wellicht ook een alternatief voor het verpleeghuis kan vormen. Het lijkt ons van belang om de resultaten van deze theoretische exercitie in een praktijksituatie te testen.

\section{LITERATUUR}

1. Commissie Modernisering Ouderenzorg. Ouderenzorg met toekomst. Den Haag, 1994.

2. Fahrenfort M., Koning C.C. Onbekend maakt onbemind. Utrecht: NZI, 1994.

3. Hermans E., Anten H.W.M., Diederiks J.P.M., Philipsen H., Beeren H.W.J.M. Patiëntkenmerken met voorspellende betekenis voor 'verkeerde-bedproblematiek' op de neurologische afdeling van een algemeen ziekenhuis. Ned Tijdschr Geneeskd 1995; 139: 890-4.

4. Wijdeven C.E.F. De verkeerde bed problematiek: een onderzoek naar de omvang van de verkeerde bed problematiek en naar factoren die hierop van invloed zijn. (Afstudeerscriptie Gezondheidswetenschappen). Maastricht: Rijksuniversiteit Limburg, 1989.

5. Coid J., Crome P. Bed blocking in Bromley. Br Med J 1986; 292:1253-6.

6. Lewis H., Purdie G. The blocked bed: a prospective study. NZ Med J 1988;101:575-6. 
7. Marchette $L$, Holloman $F$. Length of stay: significant variables. JONA 1986;16:12-20.

8. Maguire P.A., Taylor I.C., Stout R.W. Elderly patients in acute medical wards: factors predicting length of stay in hospital. Br Med J 1986;292:1251-3.

9. Zimmer J.G. Length of stay and hospital bed misutilization. Medical Care $1974 ; 12$ : 453-62.

10. N.W.O./Gebied Medische Wetenschappen. Wetenschappelijk Kaderprogramma voor het Nederlands Fersendecennium. Den Haag, 1992.

11. Hermans E. Zorgvernieuwing in de Westelijke Mijnstreek. Medisch Contact 1992; 47:435-8.

12. Nielsen M., Blenkner M., Bloom M., Downs T., Beggs H. Older persons after hospitalization: a controlled study of a home aide service. Am \Publ Health 1972;62:1094-101.

13. Zimmer J.G., Groth-Juncker A., McCusker J. A randomized controlled study of a home health care team. Am ] Publ Health 1985: 75:134-41.

14. Cable E.P., Mayers S.P. Discharge planning effect on length of hospital stay. Arch Phys Med Rehabill 1983;64:57-60.

15. W.H.O. Task Force on Stroke and other Cerebrovascular Disorders. Recommenda* tions on stroke prevention, diagnosis and therapy. Stroke 1989;20:1407-31.

16. Bisscherowx L.A., Frederiks C.M.A. Depressieve klachten en het gebruik van professionele zorg door thuiswonende ouderen. Tijdschr Gerontol Geriat 1986;17:223-6.

17. Knapen M. ., Mensink J, Ramakers C. Experimenten thuisverpleging. Nijmegen: Instituut voor Toegepaste Sociologie, 1988.

18. Fields S.D., Mackenzie C.R., Charlson M.E., Sax F.L. Cognitive impairment: can it predict the course of hospitalized patients? J Am Ger Soc 1986;34:579-85.

19. Rubin S.G., Davies G.H. Bed blocking by elderly patients in general hospital wards. Age and Ageing 1975:4:142-7.

20. Adams G.F., Hurwitz L.J. Mental barriers to recovery from stroke. Lancet 1963;ii:633-7.

21. Kotila M., Waltimo O., Niemi M.L. Laaksonen R., Lempinen M. The profile of recovery from stroke and factors influencing outcome. Stroke 1984;15:1039-44.

22. Feigenson J.S., McDowell F.H., Meese P., McCarthy M.L. Greenberg S.D. Factors influencing outcome and length of stay in a stroke rehabilitation unit Part 1 . Stroke $1977 ; 8: 651-6$.

23. Dijkstra G.J., Groothoff J.W., Dassen Th. Vergelijking van lichamelijke zorgbehoefte wan ouderen in drie typen instellingen. Tijdschr Soc Gezondheidsz 1995;73:135-40. 
HOOFDSTUK 5

Multidisciplinaire beoordeling van mogelijke vervolgzorg voor CVA-patiënten in het verkeerde bed

Een studie met 38 beoordelaars uit acht disciplines

E. Hermans, J.P.M. Diederiks, H. Philipsen, A.W. Ambergen 


\section{INTRODUCTIE EN VRAAGSTELLING}

In de praktijk van de gezondheidszorg worden elke dag tal van complexe beslissingen genomen waarvan de gevolgen verstrekkend kunnen zijn. Een van die beslissingen betreft die naar het vervolgtraject van medischspecialistisch uitbehandelde patiënten in algemene ziekenhuizen. Deze keuze is met name ingewikkeld wanneer het gaat om oudere patiënten met functionele beperkingen. Een patiëntencategorie die zowel gekenmerkt wordt door een hogere leeftijd als door relatief veel beperkingen zijn CVA-patiënten. Moeten deze patiènten naar huis worden ontslagen, naar een revalidatiecentrum, naar een verzorgingshuis, of naar een verpleeghuis? Ontslag naar huis wordt vaak belemmerd doordat er thuis onvoldoende opvang beschikbaar is. Patiënten zijn in veel gevallen verweduwd, en voor zover partners nog in leven zijn, zijn deze zelf vaak hulpbehoevend. Kinderen zijn vaak niet, of in niet voldoende mate beschikbaar voor zorgtaken. In zulke gevallen wordt in Nederland in de praktijk meestal opname in een verpleeghuis aangevraagd. Verpleeghuizen kennen echter, net als revalidatiecentra en verzorgingshuizen vaak lange wachttijden. Het gevolg is dat zich in het zorgtraject van in ziekenhuizen opgenomen CVA-patiënten een belangrijk probleem voordoet met betrekking tot de continuïteit van zorg: het verkeerde bed (Hermans et al 1995). Van een verkeerd bed is sprake wanneer een patiënt die geen medisch-specialistische hulp meer behoeft, om enigerlei reden niet uit het ziekenhuis ontslagen kan worden. Dit is een problematische situatie omdat patiënten in het verkeerde bed per definitie niet de juiste zorg ontvangen. In een kleinschalig experiment in het verzorgingsgebied van het Maaslandziekenhuis Sittard-Geleen was gebleken dat thuiszorg voor een aantal verkeerde-bedpatienten met CVA een haalbaar alternatief vormde voor een langer verblijf in het verkeerde bed (Hermans 1992), mits een meer dan reguliere proportie thuiszorg kon worden geboden.

In een eerdere studie onderzochten wij in hoeverre de optie om deze patiẻnten thuis of in een verzorgingshuis te verzorgen, zou kunnen gelden voor substantiële aantallen CVA-patiënten in het verkeerde bed. Over methode en resultaten van dit onderzoek naar substitutiemogelijkheden onder 69 verkeerde-bedpatiēnten met CVA is elders gerapporteerd (Hermans et all 1996), maar deze komen in het kort op het volgende neer. De patiënten werden -terwijl zij in het verkeerde bed verbleven-individueel op papier beschreven, en ter beoordeling van de theoretische substitutiemogelijkheden voorgelegd aan een vast panel van zorgverleners uit 4 disciplines: een huisarts, een hoofdwijkverpleegkundige een hoofd zorg van een instelling 
voor gezinsverzorging, en een hoofd verzorging van een verzorgingshuis. Dit panel concludeerde na gezamenlijke bespreking van de patiënten op basis van consensus dat 28 van de 69 patiënten mogelijk thuis of in een verzorgingshuis konden worden verzorgd. Dit waren 7 van de 8 patiënten die later daadwerkelijk naar huis werden ontslagen, en 21 van de 61 patiënten die in werkelijkheid naar een revalidatiecentrum of verpleeghuis ontslagen werden. Aldus ontstonden op basis van het feitelijke en het theoretisch mogelijk geachte ontslagpatroon drie groepen patiënten: een groep die feitelijk naar huis terugkeerde (thuisgroep), een groep mét theoretische substitutiemogelijkheden (substitutiegroep) en een groep zonder theoretische substitutiemogelijkheden (niet-substitutiegroep).

Uit follow-up onderzoek bleek dat het consensus-oordeel van ons oorspronkelijke panel geassocieerd was met overleving op lange termijn: de patiënten die door het panel substitueerbaar werden geacht, waren drie jaar na ziekenhuisontslag significant vaker nog in leven dan de anderen.

Wij stelden ons de vraag welke waarde kon worden toegekend aan deze bevindingen. Het panelexperiment had zich afgespeeld in een beperkte regionale kontekst, en het panel bestond uit vier willekeurige vertegenwoordigers van vier extramurale zorgverlenende disciplines. Was er sprake van een toevallige regionale bevinding, of zouden zorgverleners uit andere regio's en uit andere disciplines tot dezelfde conclusies komen? De waarde van het paneloordeel zou naar onze mening sterk afhankelijk zijn van de mate van reproduceerbaarheid ervan. Wij hebben deze reproduceerbaarheid getest door te onderzoeken in hoeverre een breed panel van 40 zorgverleners (panel II) uit 8 verschillende disciplines ten aanzien van deze patièntenpopulatie tot hetzelfde oordeel zou komen als het oorspronkelijk panel (panel I). Bij de reproduceerbaarheid gaat het niet alleen om de overall overeenstemming tussen beide panels, maar ook on de vraag naar de variatie in overeenstemming tussen de individuele beoordelaars en groepen beoordelaars (betrokken disciplines), alsmede naar de variatie in overeenstemming op casusniveau. Het is tenslotte van belang om vast te stellen of variatie in overeenstemming toe te schrijven is aan informatieverschillen in de casusbeschrijvingen. De vraagstellingen zijn derhalve:

1 Hoe groot is de overeenstemming tussen beide panels?

2a Hoe is de variatie in overeenstemming bij de individuele leden van panel II?

$2 \mathrm{~b}$ Hoe is de variatie in overeenstemming tussen de betrokken disciplines?

3a Hoe is de variatie in overeenstemming tussen de casus?

$3 \mathrm{~b}$ Is de variatie op casusniveau toe te schrijven aan eventuele verschillen in informatie in de casusbeschrijvingen? 


\section{METHODE}

Voor panel II werd een convenience-sample van 40 beoordelaars uit 8 disciplines (5 uit elke discipline) benaderd. In overzicht I is naar discipline aangegeven welke respondenten benaderd zijn.

Zoals uit overzicht I blijkt, zijn in panel II zowel zorgverleners opgenomen van de 4 disciplines die vertegenwoordigd waren in panel $I$, als zorgverleners uit 4 andere disciplines.

Het response percentage van de 40 aangezochte beoordelaars was hoog $(95 \%) ;$ slechts een hoofdwijkverpleegkundige en een revalidatiearts stuurden het formulier niet terug, zodat de beoordelingen van 38 beoordelaars in het onderzoek zijn verwerkt. Geen van de leden van panel II waren bij het regionale thuiszorg-experiment voor verkeerde-bedpatiënten met CVA betrokken geweest. Hierdoor werd bias in het onderhavige onderzoek uitgesloten. Het nadeel was anderzijds dat de leden van panell I niet bekend waren met het feit dat substituerende thuiszorg voor verkeerde-bedpatienten met CVA in de praktijk mogelijk was gebleken. Ook waren zij niet -en de leden van panel II wél- bekend met de in de Introductie vermelde gegevens betreffende het feitelijke en het theoretisch mogelijke ontslagpatroon. Van beide feiten moesten zij dus eerst op de hoogte gesteld worden. Vervolgens werden aan de individuele leden van panel II patiëntbeschrijvingen aangeboden van een steekproef van 21 patiënten uit de oorspronkelijke populatie van 69: de 7 patiënten uit de thuisgroep, alsmede 7 willekeurige patiënten uit de substitutiegroep en 7 willekeurige patiënten uit de niet-substitutiegroep. De leden van panel II werden ervan op de hoogte gesteld dat de steekproef bestond uit steeds zeven patienten uit elkvan de drie groepen. Hen werd gevraagd om de 21 casussen in te delen in de drie genoemde groepen van 7 . Het gegeven dat de drie groepen bestonden, impliceerde dat de leden van panell II zelf niet meer hoefden te beslissen of substitutie mogelijk was; dit was een gegeven. Overzicht II bevat de casusbeschrijvingen van de 21 patiënten zoals deze aan de leden van panel II zijn aangeboden.

Panel I had behalve deze beschrijvingen voor elke patiënt scores (4-puntsschalen) over het lichamelijk en psychisch onvermogen ter beschikking gehad, alsmede een overzicht van de medische, verpleegkundige en verzorgende activiteiten waarbij de patiënten hulp nodig hadden. Een ander verschil tussen beide experimenten was dat in panel II geen consensus-stap was ingebouwd. De beoordelaars van panel II kwamen individueel tot hun oordeel, terwijl panel I na gezamenlijke patiëntbesprekingen tot een consensus oordeel kwam. 


\section{OVERZICHT I}

Medisch specialisme neurologie:

Vier neurologen

Een arts-assistent neurologie

Verpleeghuisgeneeskunde:

Vijf verpleeghuisartsen

Revalidatiegeneeskunde:

Vijf revalidatieartsen

Ziekenhuisverpleegkunde:

Vier verpleegkundige hoofden van een afdeting neuralogie

Een verpleegkundig hoofd van een short-stay afdeling (voormalig hoofd afdeling neurologie)

Huisartsgeneeskunte:

Vijf huisartsen

Verzorgingshuis:

Twee hoofden van een verzorgingshuis-afdeling

Twee hoofden verzorging van een verzorgingshuis

Een adjunct-directeur/hoofd verzorging van een verzorgingshuis

Wijkwerpleging:

Twee hoofdwijkverpleegkundigen

Een verpleegkundig specialist neurologie

Een transferverpleegkundige

Een wijkverpleegkundige

Gezinswerzorging:

Vijf leidinggevendem

\section{OVERZICHT II}

GROEP I

1. Vrouw $80 \mathrm{jr}$.

Loopt zelfstandig met looprekje. Toezicht nodig bij wassen van onderlichaam. Woonde in bejaardenwoning. Had geen mantelzarg nodig. Heeft goede kontakten met haar kinderen.

2. Vrouw $77 \mathrm{jr}$.

Woonde woorafgaand aan opname samen met echtgenoot. Dit ging goed. Beschilkt nog over diverse eigen mogelijkheden. 


\section{Vrouw $82 \mathrm{jr}$.}

Apractisch; handetingen zijn niet zorgvuldig. Dysfasie. Woont met echtgenoot. Deze is inwalide en werd door haar verzorgd. Ze is nu zelf gedeeltelijk afhankelijk. Heeft kinderen die overdag werken.

\section{Vrouw $84 \mathrm{jr}$.}

Lichte afasie. Heeft emige hulp nodig met wassen. Loopt redelijk alleen. Toilet zelfstandig. Psychisch goed. Dochter wil haar graag thuis hebben en wil ook helpen in de zorg.

\section{Man $71 \mathrm{jr}$.}

Heeft nu nog hulp nodig bij wassen, lopen, toilet. Gaat echter wooruit. Lichte mate van urineuncontinerntie. Nieuwe dingen zijn hem moeilijk aan te leren. Automatismen zijn redelijk. Woont met echtgenote; kinderen wonen in de buurt. Voorafgaand aan opname waren er geen bijzonderheden.

\section{Vrouw $58 \mathrm{jr}$}

Wordt met wassem en toiletgang geholpen. Begripsgestoord. Rolstoelpatiënt. Echtgenoot is zeer hulpbereid.

\section{Man $65 \mathrm{jr}$.}

ADL-afhankelijk (wassen, aankleden, transfer). Motorische afasie. Woonde thuis met echtgenote. Zeven kinderen.

\section{GROEP II}

\section{Man $78 \mathrm{jr}$.}

Moet verzorgd en gewassen worden. Is soms verward. Woont samen met zorgafharikelijke echtgenote. Kan op termijn wellicht naar een verzorgingshuis.

\section{Man $81 \mathrm{jr}$.}

Hulp riodig bij toiletbezoek, wassen, lopen, zitten, eten. Walneigingen. Begripsstoornissen. Woont. alleen, maar heeft familie in de buurt. Op termijn wellicht verzorgingshuis.

10. Vrounw $81 \mathrm{jir}$.

Loopt met loopfiets. Walt geregeld. Moet met alles volledig geholpen worden. Geheugenstoornis. Alarmering gebruikt ze niet. Gedesoriënteerd in tijd. Achterdochtig. Woont in groot huis. Werd regelmatig op de grond liggend aangetroffen. Buren hielden o ogje in het zeil. Hoorden's nachts wakk gestommel.

11. Wroum 83 ij.

Wat apractisch met wassen en aankleden. Soms een beetje verward. Alleenwonend. Geen kinderen.

12. Vrouw $70 \mathrm{jr}$.

ADL geheel afhankelijk. Rolstoeler; kan deze niet zeif bedienen. Erg huilerig. Gezonde echtgenoot heeft lange tijd thuis alle hulp geboden; hij kan het thans, niet aan. Er was wijkverpleging ( $2 x$ per week) en gezinszorg ( $1 x$ per week). Patiènte zou thans ook nog dagbehandeling (2 dagen per week) kunnen krïjgen. 
13. Vrouw $71 \mathrm{jr}$.

Wordt met alles geholpen. Flinke verpleegbehoefte. Bed-stoel-patient. Kan niet staan. Slechte zitbar lans. Hardhorend. Psychisch weinig problemen. Woonde voor opirame met echtgenoot. Had $1 x$ per week wijkverpleging. Was verder zelfstandig.

\section{Man 60 jr.}

Loopt onder begeleiding. Heeft toezicht nodig. Woont bij zoon die overdag werkt. Drie zussen (in de zeventig) verzorgden hem. Dit ging niet meer. AMW zorgt woor vervangende woonruimte.

\section{GROEP III}

15. Man $73 \mathrm{jr}$.

Grote intracerebrale bloeding met ventrikeldoorbraak. Woonde samen met hulpbehoevende echtgenote. Verder geen verwanten. Hij heeft nagenoeg geen eigen mogelijkheden meer.

16. Man $80 \mathrm{jr}$.

ADL-afhankelijk. Redelijke zitbalans. Mobiliteit nihil. Moeilijk te hanteren patiënt. Geen ziek te-inzicht. Woont alleen. Twee werkende zonen zonder mogelijkheden on de patiënt te ondersteunen.

17. Vrouw $84 \mathrm{jr}$.

ADL volledig afhankelijk. Staapt hele dagen. Moeilijk wekbaar. Bedverpleging. Geen contact mogelijk. Woont alleen. Familie ziet geen mogelijkheden tot hulp bij verzorging.

18. Man $50 \mathrm{jr}$.

Wordt met alles geholpen. Geen eigen mogelijkheden. Incontinent voor urine en faeces. Depressief. Waandenkbeelder. Echtgenote kan hem thüs miet verplegen.

19. Vrouw $81 \mathrm{jr}$.

Redelijk zelfstandig in de ADL als de kleding goed wordt klaargelegd. Redelijk mobiel. Licht, psychisch onvermogen. Visusstoornissen. Pientere dame. Had reeds enige wijkverpleging vooraf aan opname. Thuis weet zij alles vlelkkeloos te vinden. Kinderen winden thusisplaatsing niet veilig genoeg.

20. Vrouw $72 \mathrm{jr}$.

Volledig AOL-afhankelijk; ook bij tolletbezoek. Soms vergeetachtig. Wachttijd op verpleeghuis wellicht in bejaardenhuis door te brengen. Geen relaties of verwantert.

21. Vrouw $81 \mathrm{jr}$.

Bed-stoell patiënte. Wordt met wassen geholpen. Zeer passief, dit remt haar mogelijkheden. Woonde bij dochter. Was vooraf aan opname onafhankelijk, hoewel ze looprekje en rolstoel had.

(Ten behoeve wan de overzichtelijkheid zijn de patiënten in dit overzicht gerangschikt in de in de Introductie genoemde drie groepen. Uiteraard zijn zij niet in deze, maar in willekeurige volgorde en niet voorzien van de groepsaanduiding aan de beoordelaars van panel II aangeboden). 
Omdat de patiêntbeschrijvingen verschillen in informatie konden bevatten, was de mogelijkheid aanwezig dat beoordelingsverschillen tussen beoordelaars uit panel II terug te voeren waren op verschillen in aangeleverde informatie. Wij hebben daarom getracht de verschillen in informatie tussen de patiëntbeschrijvingen te objectiveren door de casussen door 5 onafhankelijke zorgdeskundigen te laten beoordelen op de aanwezigheid van informatie over elk van de vier volgende aspecten:

- informatie over de ziekte-ernst van patiënt

- informatie over de psychische toestand van patiënt,

- informatie over de mantelzorgsituatie van patiënt,

- informatie over de zorgafhankelijkheid van patiënt.

De vijf onathankelijke zorgdeskundigen waren een universitair docent gezondheidswetenschappen, een universitair docent huisartsgeneeskunde, een verplegingswetenschapper, een locatiemanager van een gecombineerd verpleeghuis en een onderzoeker in de verpleeghuiswetenschappen. Deze beoordeling vond voor elke casus, en ten aanzien van elk afzonderlijk aspect plaats op een 4 punts-schaal, varièrend van 'weinig informatie' (score 1) tot 'veel informatie'(score 4).

De kansverdeling behorend bij het beschreven experiment met de 38 beoordelaars van panel II is de multipele hypergeometrische verdeling (Agresti 1990). Op basis van deze verdeling konden de kansen berekend worden voor het aantal patienten dat de beoordelaars "goed" hadden, dat wil zeggen overeenstemmend met de beoordeling van panel I. Eveneens op basis van genoemde verdeling werden de kansen op unieke patronen over de drie groepen berekend. De mate van overeenstemming tussen de beoordelaars is uitgedrukt in diverse varianten van Cohen's Kappa: de enkelvoudige Kappa voor overeenstemming tussen 2 beoordelingen, de ongewogen groepskappa voor overeenstemming binnen eén groep, en de gewogen groepskappa voor overeenstemming tussen een groep en een standaard (Popping 1995). Cohen's Kappa is een statistische maat die corrigeert voor overeenstemming die tot stand komt op basis van toeval. Bij de interpretatie van de gevonden Kappa-waarden hebben wij de categorisering van Landis en Koch (1977) gevolgd. Volgens deze indiceren Kappa-waarden tussen 0,20 en 0,40 "fair agreement", 0,40 tot 0,60 "moderate agreement", 0,60 tot 0,80 "substantial agreement", en $>0,80$ "excellent agreement". 


\section{RESULTATEN}

\subsection{DE OVEREENSTEMMING TUSSEN DE BEIDE PANELS ALS GEHEEL}

De oordelen van de beoordelaars uit panel II hadden gemiddeld een redelijke overeenstemming met de beoordeling door panel I. Dit is weergegeven in tabel 1. De gemiddelde Kappa komt uit op 0,48.

De reproductie van het oordeel van panel $I$ is voorts op twee manieren geanalyseerd. Ten eerste is gekeken naar het totaal aantal patiënten waarover een beoordelaar overeenstemde met panel I. Theoretisch kan dit aantal variëren van 0 - 21. In panel II varieert het aantal overeenstemmende patiënten van 10 - 18. In tabel 2 is de frequentieverdeling van het aantal beoordelaars met een bepaalde mate van overeenstemming en de rechter overschrijdingskans daarop volgens de multipele hypergeometrische verdeling weergegeven. Wanneer het criterium van $\mathrm{p}<0,05$ gehanteerd wordt, zijn er 7 beoordelaars waarbij de reproductie van het oordeel van panel $\mathbb{l}$, onvoldoende is. Dit betreft 2 wijkverpleegkundigen, 2 hoofdverpleegkundigen uit het ziekenhuis, 1 hoofd verzorgingshuis, 1 hoofd gezinsverzorging en 1 revalidatiearts.

Vervolgens zijn de patronen op overeenstemming bezien (tabel 3). Eenzelfde totale overeenstemming kan immers op verschillende manieren tot stand komen, behoudens een overeenstemming van 0 of 21 patiënten. De 38 leden van panel II produceerden 20 overeenstemmingspatronen. Relatief het meest komen de patronen 5-4-5 en 6-5-5 (in respectievelijk de thuis-, de substitutie- en de niet-substitutiegroep) voor. Zoals ook al uit tabel 2 bleek, reproduceerde geen enkel lid van panel II het oordeel van panel I volledig.

\subsection{DE DIFFERENTIËLE OVEREENSTEMMING EN DE OVEREENSTEMMING BINNEN DE DIVERSE BEROEPSGROEPEN}

In tabel 4 is per beroepsgroep zowel de overeenstemming met panel $\mathbb{I}_{v}$ als de onderlinge overeenstemming binnen de diverse beroepsgroepen weergegeven. De gemiddelde overeenstemming per beroepsgroep uit panel II met het oordeel van panel I bewoog zich voor 6 van de 8 disciplines tussen Kappa-waarden van 0,47 en 0,51. Opvallend was dat de twee verpleegkundige beroepsgroepen buiten deze range vielen: de verpleegkundige ziekenhuis-afdelingshoofden $(0,44)$ en de wijkverpleegkundigen $(0,38)$.

Op grond van de Kappa's van de individuele beoordelaars was de overeenstemming met het oordeel van panel I significant $(\mathrm{p}<0,05)$ voor 31 van de 38 individuele beoordelaars. Van 2 wijkverpleegkundigen, 2 verpleegkundige 
TABEL 1. GEMIODELDE OVEREENSTEMMING TUSSEN BEOORDELAARS VAN PANEL II MET OORDEEL VAN PANEL I (afgerond op hele aantallen)

\begin{tabular}{llll} 
& Panel II & & \\
\cline { 2 - 4 } Panel I & Thurisgroep & Substitutiegroep & Niet-substitutie groep \\
\hline Thuisgroep & 5,21 & 1,45 & 0,34 \\
Substitultiegroep & 1,03 & 3,89 & 2,08 \\
Niet-substitutiegroep & 0,76 & 1,66 & 4,58 \\
\hline
\end{tabular}

TABEL 2. OVEREENSTEMMING PANEL I -II OP HET TOTAAL AANTAL PATIËMTEN

\begin{tabular}{lll}
\hline $\begin{array}{l}\text { Aantal patienten } \\
\text { Qvereensternmend }\end{array}$ & Aantal beoordelaars & $p$ \\
\hline 10 & 2 & 0,13 \\
11 & 5 & 0,06 \\
12 & 4 & 0,02 \\
13 & 6 & $8,2310^{-3}$ \\
14 & 8 & $2,3710^{-3}$ \\
15 & 4 & $5,3710^{-4}$ \\
16 & 7 & $1,1410^{-4}$ \\
17 & 1 & $2,0910^{-5}$ \\
18 & 1 & $2,0910^{-5}$ \\
& 38 & \\
\hline
\end{tabular}

zilekenhuis-afdelingshoofden, 1 revalidatiearts, 1 vertegenwoordiger van de gezinsverzorging en 1 afdelingshoofd uit een verzorgingshuis had het oordeel geen significante overeenstemming met dat van panel I. Van de huisartsen, neurologen en verpleeghuisartsen hadden alle individuele oordelen een significante overeenstemming met het oordeel van panel $\mathbb{I}$. De onderlinge overeenstemming tussen de beoordelaars van de diverse beroepsgroepen uit panel II, was het hoogst onder de verpleeghuisartsen en de afdelingshoofden van de verzorgingshuizen en de leidinggevenden van de gezinsverzorging. Opvallend was dat de oordelen van de wijkverpleegkundigen de laagste overeenstemming hadden met de beoordeling van panel I, maar een relatief hoge onderlinge overeenstemming (Kappa: 0,54). 
TABEL 3. OVEREENSTEMMING PANEL I - II NAAR PATIËNTENGROEP*.

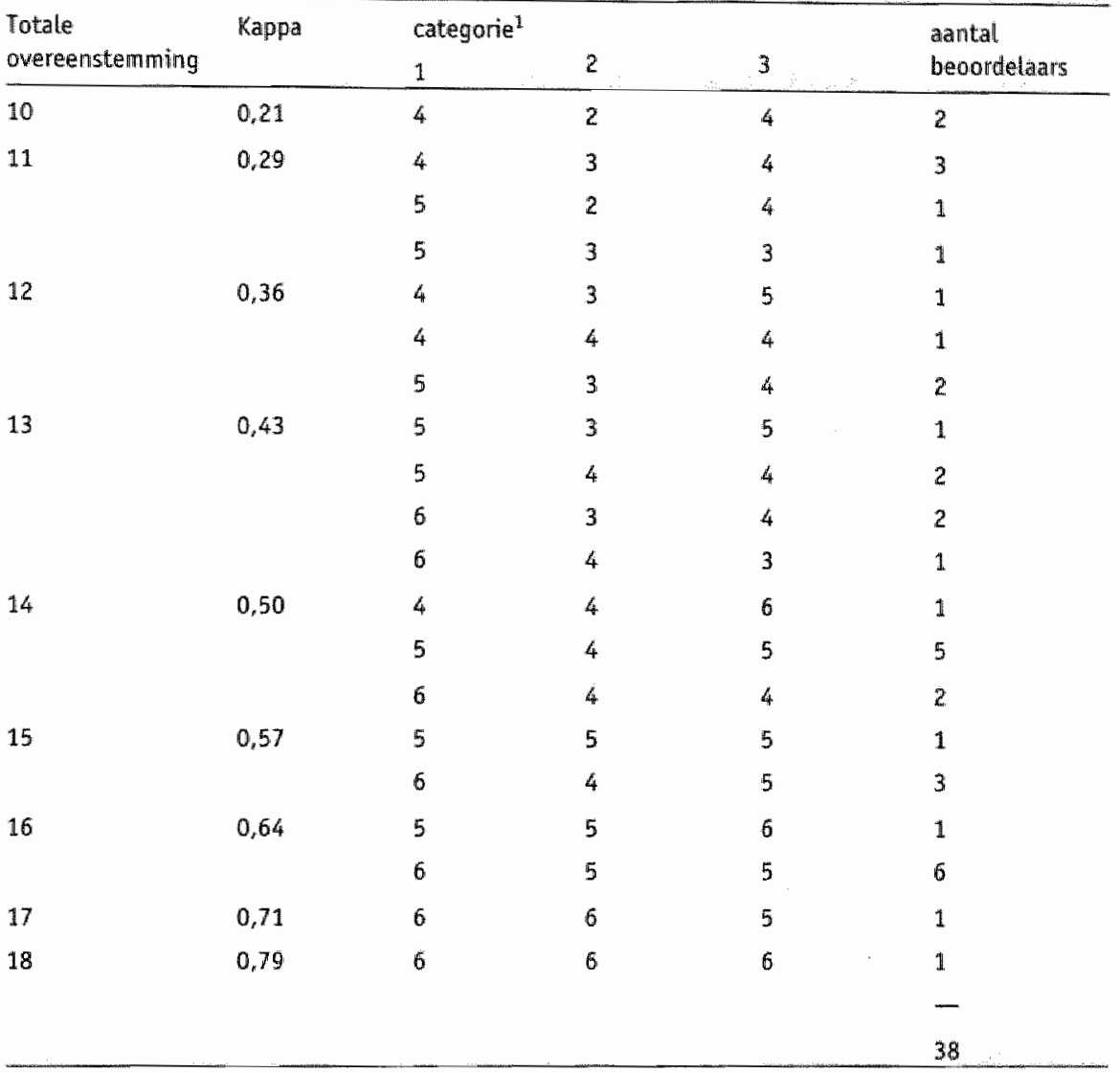

1 =thuis-, 2 -substitutie-, 3 miet- substitutiegroep.

In tabel 5 is de combinatie in beeld gebracht van enerzijds de overeenstemming per beroepsgroep met panel I en anderzijds de onderlinge overeenstemming binnen de beroepsgroepen. Hiertoe zijn de Kappa's per beroepsgroep voor de intra- en interdisciplinaire overeenstemming gerangordend en ingedeeld in lagere (ranggetal $<5$ ) en hogere (ranggetal $>4$ ).

We zien dat de verpleeghuisartsen, de afdelingshoofden van de verzorgingshuizen en de leidinggevenden van de gezinsverzorging zowel een hoge over- 
TABEL 4. OVEREENSTEMMING PER BEROEPSGROEP MET PANEL II EN ONIDERLING (COHEN'S KAPPA)

\begin{tabular}{lll}
\hline & \multicolumn{2}{c}{ Overeenstemming (kappa/(s.e.) } \\
\cline { 2 - 3 } Met panel I & Onderling per beroepsgroep \\
\hline Neurologen & $0,47(0,11)$ & $0,46(0,09)$ \\
Verpleeglhuisartsen & $0,50(0,12)$ & $0,57(0,10)$ \\
Revalidlatieartsen & $0,48(0,11)$ & $0,46(0,10)$ \\
Hoofdverpleegkundigen & $0,44(0,11)$ & $0,51(0,09)$ \\
ziekenhuis & & \\
Huisartsen & $0,51(0,11)$ & $0,51(0,08)$ \\
Verzorgingshuizen & $0,50(0,12)$ & $0,57(0,10)$ \\
Wijkverpleging & $0,38(0,13)$ & $0,54(0,09)$ \\
Gezinsverzorging & $0,51(0,12)$ & $0,59(0,09)$ \\
Totaal Panel II & $0,47(0,12)$ & $0,52(0,09)$ \\
\hline
\end{tabular}

TABEL 5. COMBIMATIE VAN OVEREENSTEMMING PER BEROEPSGROEP MET PANEL I EN ONDERLING

\begin{tabular}{|c|c|c|}
\hline \multirow[b]{2}{*}{$\begin{array}{l}\text { Ondertinge overeenstemming } \\
\text { beroepsigroep }\end{array}$} & \multicolumn{2}{|c|}{ Overeenstemming met panel I } \\
\hline & $>$ gemiddeld & $<$ gemiddeld \\
\hline$>$ gemiddeld & $\begin{array}{l}\text { Verpleeghuisartsen } \\
\text { Verzorgingshunzen } \\
\text { Gezinswerzorging }\end{array}$ & Wijkverpleging \\
\hline$<$ gemidldeld & Huisartsen & $\begin{array}{l}\text { Ziekenhuisverpleging } \\
\text { Neurologen }\end{array}$ \\
\hline & & Revalidatieartsen \\
\hline
\end{tabular}

eenstemming met panell als een hoge onderlinge overeenstemming hebben. De neurologen, revalidatieartsen en ziekenhuisverpleging scoorden op beide dimensies laag. Opvallend is dat deze tweedeling goeddeels overeenkomt met de verdeling tussen vertegenwoordigers van beroepen uit de 'care' - en 'cure'-sector. De huisartsen en de wijkverpleegkundigen namen de tussenposities in.

\subsection{DE BEOORDELINGSRESULTATEN OP CASUSNIVEAU}

De reproductie van het oordeel van panel I dient ook bezien te worden op casusniveau. Wanneer van bepaalde patiënten het oorspronkelijk oordeel niet kan worden gereproduceerd, is de panelmethode immers minder 
TABEL 6. OVEREENSTEMMING OP CASUSNIVEAU (GEORDEND NAAR OVEREENISTEMMING)

\begin{tabular}{|c|c|c|c|c|c|}
\hline \multirow[b]{2}{*}{ Casusno. } & \multicolumn{3}{|c|}{$\begin{array}{l}\text { Aantal beoordelaars in } \\
\text { Categorie }{ }^{12}\end{array}$} & \multirow[t]{2}{*}{$\begin{array}{l}\text { Fractie } \\
\text { overeenstemming }\end{array}$} & \multirow[t]{2}{*}{$\begin{array}{l}\text { Variatie- } \\
\text { Coéfficiènt }^{3}\end{array}$} \\
\hline & 1 & 2 & 3 & & \\
\hline 4 & 38 & 0 & 0 & 1,00 & 0,00 \\
\hline 15 & 0 & 0 & 38 & 1,00 & 0,00 \\
\hline 2 & 37 & 1 & 0 & 0,97 & 0,08 \\
\hline 5 & 37 & 1 & 0 & 0,97 & 0,08 \\
\hline 18 & 0 & 1 & 37 & 0,97 & 0,08 \\
\hline 1 & 36 & 2 & 0 & 0,95 & 0.08 \\
\hline 17 & 0 & 2 & 36 & 0,95 & 0,08 \\
\hline 16 & 0 & 7 & 31 & 0,82 & 0.45 \\
\hline 8 & 1 & 31 & 6 & 0,82 & 0,46 \\
\hline 6 & 31 & 5 & 2 & 0,82 & 0,47 \\
\hline 14 & 12 & 26 & 0 & 0,68 & 0,65 \\
\hline 20 & 0 & 14 & 24 & 0,63 & 0,70 \\
\hline 11 & 15 & 23 & 0 & 0,61 & 0,72 \\
\hline 9 & 2 & 23 & 13 & 0,61 & 0,77 \\
\hline 12 & 6 & 22 & 10 & 0,58 & 0,86 \\
\hline 7 & 19 & 15 & 4 & 0.50 & 0,87 \\
\hline 13 & 2 & 13 & 23 & 0,34 & 0,77 \\
\hline 10 & 1 & 10 & 27 & 0,26 & 0,64 \\
\hline 21 & 4 & 26 & 8 & 0,21 & 0,71 \\
\hline 19 & 25 & 13 & 0 & 0,00 & 0,68 \\
\hline 3 & 0 & 31 & 7 & 0,00 & 0,45 \\
\hline
\end{tabular}

1 -thuis, 2-substitutie-, 3 miet-substitutiegroep. ${ }^{2}$ Vetgedrukte getallen geven de "junste" categone

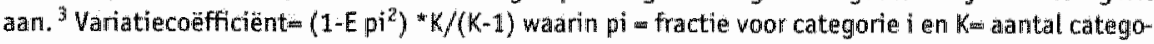
rieën.

geschikt. Teneinde een ordening te krijgen van beter en slechter beoordeelde casussen zijn twee criteria gehanteerd: de mate van variatie over de beoordelaars met de Index voor Kwalitatieve Variatie, variërend van 0 (geen variatie), tot 1 (maximale variatie) (Weisberg 1992) en de grootte van de fractie "goede" beoordelaars, dat wil zeggen de beoordelaars die de patiënten overeenkom- 
TABEL 7. OVEREENSTEMMIMG NAAR INFORMATIEF GEHALTE CASUSBESCHRIJVINGENI?

\begin{tabular}{llll}
\hline & \multicolumn{2}{l}{ Overeenstemming } & Moog \\
\cline { 2 - 4 } $\begin{array}{l}\text { Informatiegehalte in } \\
\text { patiëntbeschrijving over: }\end{array}$ & Laag & & \\
\hline Ziekte-ernst & 2,3 & 2,0 & 2,5 \\
Psychische toestand & 2,2 & 2,3 & 2,2 \\
Zorgafhankelijkheid & 3,0 & 3,0 & 3,0 \\
Mantelzorgsituatie & 2,4 & 2,9 & 3,0 \\
Gemiddeld & 2,5 & 2,6 & 2,7 \\
\hline
\end{tabular}

${ }^{4}$ Gemiddeld over 5 beoordelaars. ${ }^{2}$ De beoordeling wan het informatieg ehalte van de castus geschiedde op een 4-puntsschaal: 4 - veel informatie, 1 - weinig of geen informatie.

stig panel I geclassificeerd hadden. Er ontstaan dan drie groepen: een groep casussen met lage variatiecoëfficiënten en "goede" beoordelaars $(n=7)$, een groep met hoge variatiecoëfficiënten en bovendien een meerderheid van de beoordelaars in een "verkeerde" categorie $(n=6)$ en een tussen-groep met weliswaar grote variatie, maar met een meerderheid van "goede" beoordelingen $(n=8)$.

De vraag is nu of de variatie op casusniveau is toe te schrijven aan variaties in de casusbeschrijvingen. Vijf onafhankelijke zorgdeskundigen hebben hiertoe de casusbeschrijvingen beoordeeld op de aanwezigheid van informatie over vier aspecten: ernst van de ziekte, psychische toestand, zorgafhankelijkheid, en mantelzorgsituatie. Dit gebeurde voor elk aspect op een schaal van 1 (weinig informatie in de casusbeschrijving) tot 4 (veel informatie). Voor de casussen in elk van de 3 groepen (met respectievelijk hoge, redelijke en lage overeenstemming) is de gemiddelde score ten aanzien van de vier aspecten (ziekte-ernst, psychische toestand, zorgafhankelijkheid en mantelzorgsituatie) berekend. Hiertoe werden de gemiddelde beoordelingen per casus van de zorgdeskundigen berekend en in verband gebracht met de groepen casussen zoals die in tabel 6 beschreven zijn.

Uit tabel 7 komt naar voren dat het oordeel meer in overeenstemming met het oordeel van panel I lijkt naarmate de casus meer informatie bevatte over mantelzorgaspecten. Deze trend was statistisch niet significant $10,05<$ $p<0,10$ ). Ten aanzien van de ziekte-ernst ontbrak een trend tussen de 3 groepen, maar de casussen waarover hoge overeenstemming bestond met panel I bevatte gemiddeld de meeste informatie over de ziekte-ernst. De hoeveelheid informatie over de psychische toestand en de zorgafhankelijk- 
heid in de casusbeschrijving had geen invloed op overeenstemming tussen de panels.

\section{DISCUSSIE}

Aan hulpverleners van 8 verschillende disciplines werd op basis van summiere informatie gevraagd om 21 CVA-patiënten die in het verkeerde bed lagen, in te delen in 3 groepen: een groep die naar huis ontslagen zou worden, een groep die niet naar huis ontslagen zou worden, maar wel potentiële mogelijkheden had om thuis of in een verzorgingshuis verzorgd te worden (substitutie), en een groep zonder substitutiemogelijkheden. Het bestaan van de 3 groepen was gegeven, dit onderscheid was gemaakt door een eerder panel. Deze studie bevestigt de waarde van het oorspronkelijk paneloordeel doordat dit op basis van betrekkelijk summiere informatie in redelijke mate reproduceerbaar is. Er bestaan in dit opzicht geen grote verschillen tussen de disciplines, met uitzondering van de wijkverpleging die de geringste overeenstemming vertoont met het oorspronkelijke paneloordeel. De overeenstemming binnen de disciplines is gemiddeld genomen van een zelfde niveau met eveneens geringe variatie. De intramurale disciplines combineren een relatief geringe onderlinge consensus met een relatief geringere overeenstemming met het oorspronkelijk paneloordeel. Huisartsen, verpleeghuisartsen, hoofden van verzorgingshuizen en de gezinsverzorging vertonen de grootste overeenstemming met het oordeel van het oorspronkelijke panel, dat met uitzondering van de verpleeghuisartsen juist uit deze disciplines bestond. Al met al lijkt het er dus op dat de vertegenwoordigers van de op care gerichte disciplines andere criteria aanleggen bij de beoordeling van doorstroommo gelijkheden van uitbehandelde CVA-patiënten dan die van de specialistische disciplines en de ziekenhuisverpleging. Als bedacht wordt dat het oordeel van het oorspronkelijke panel een consensus-oordeel was, lijkt de conclusie gerechtvaardigd dat de extramurale disciplines, met uizondering van de wijkverpleging, een kwalitatief beter oordeel geven, zeer waarschijnlijk door hun positie in de gezondheidszorg en het daarmee samenhangende betere inzicht in de (on-) mogelijkheden van thuiszorg.

De reproductie van het paneloordeel was veel beter dan op grond van toeval verwacht kon worden. Aangezien het reproductie-oordeel, anders dam het oorspronkelijk paneloordeel, op individuele uitspraken en op betrekkelijk geringe, routinematig voorhanden zijnde informatie gebaseerd was, kan geconcludeerd worden dat summiere inhoudelijke informatie voldoende is 
voor individuele zorgverleners om een inhoudelijke afweging te maken. De resultaten wijzen erop dat meer informatie over de mantelzorgsituatie het beoordelingsresulaat nog zou kunnen verbeteren. Om onder patiënten met een dergelijke complexe problematiek de basale groepsindeling te maken, zal inhoudelijk multidisciplinair overleg noodzakelijk blijven. Met name zal dit zijn vruchten afwerpen voor het onderscheiden van de tussengroep die in de huidige situatie niet naar huis ontslagen wordt, maar met toevoegingen aan de reguliere zorg wel thuis of in een verzorgingshuis kan verblijven.

De resultaten van deze studie geven aanleiding tot het voorstellen van een werkwijze waarbij het vervolgzorgtraject van uitbehandelde CVA-patiënten beoordeeld wordt door vertegenwoordigers van in elk geval care-disciplines (verpleeghuisgeneeskunde, verzorgingshuizen, gezinsverzorging) op grond van informatie die routinematig in ziekenhuizen voorhanden is over de ziekte-ernst, de psychische toestand, de zorgafhankelijkheid en informatie over de mantelzorgsituatie.

\section{LITERATUUR}

1. Hermans E., Anten H.W.M., Diederiks J.P.M., Philipsen H., Beeren H.W.J.M. Patiëntkenmerken met voorspellende betekenis voor 'verkeerde bed problematiek' op de neurologische afdeling van een algemeen ziekenhuis. Ned Tijdschr Geneesk 1995; 139: 890-4.

2. Hermans E. Project 'Integraal Regionaal'; zorgvernieuwing in de Westelijke Mijnstreek. Medisch Contact 1992; 47: 435-8.

3. Hermans E. Anten H.W.M., Diederiks J.P.M."Philipsen H., Hameleers B., Sikkes-Mekel O., Schepers A. CVA-patiënten in het 'verkeerde bed'; een onderzoek naar theoretische alternatieven. Tijdschr Soc Gezondheidsz 1996; 74: 96-100.

4. Agresti A. Categorical Data Analysis. Wiley, New York 1990.

5. Popping R., Agree; Users manual. Groningen, The Netherlands 1995.

6. Landlis J.R., Koch G.G. The measurement of observer agreement for categorical data. Biometrics 1977; 33: 159-74.

7. Weisberg H.F. Central Tendency and Variability. Sage, Newbury Park, 1992. 
HOOFDSTUK 6

Lange termijn uitkomsten en substitutiewinst onder CVA-patiënten in het verkeerde bed

E. Hermans, H.W.M. Anten, J.P.M. Diederiks, H. Philipsen

Geaccepteerd voor publicatie in: Tijdschrift voor Gezondheidswetenschappen 


\section{SAMENVATTING}

In een eerder onderzoek onder CVA-patiënten in het verkeerde bed kwam een panel van zorgverleners op theoretische gronden tot de conclusie dat een derde deel van deze patiënten thuis of in een verzorgingshuis verpleegd of verzorgd kon worden als alternatief woor een langer verblijf in het verkeerde bed.

In dit onderzoek is getracht aan de hand van het werkelijke beloop gedurende drie jaar volgend op ziekenhuisontslag onder deze patiënten een indicatie te geven van de omvang van de haalbare substitutie. Van de 65 gevolgde en door het panel gescreende patiënten waren er na drie jaar 26 nog in leven, en woonden er 11 thuis of in een verzorgingshuis. Driejaars overleving was significant geassocieerd met het paneloordeel over substitutie. Het gehanteerde rekenmodel leverde onder deze 65 patiënten een harde substitutiewinst op van 65 verpleegmaanden en een zachte substitutiewinst van 306 verpleegmaanden in revalidatiecentra en vooral verpleeghuizen. Aanbevolen wordt om de werkelijk haalbare substitutie te onderzoeken in praktische experimenten. 


\section{INTRODUCTIE}

Substitutie is in de gezondheidszorg een actueel onderwerp. Recente adviezen en onderzoeken wijzen op de haalbaarheid van vergaande vormen van substitutie (Commissie Structuur en Financering Gezondheidszorg 1987, Commissie Modernisering Ouderenzorg 1994, Kemp 1994). Substitutie kan op gang gebracht worden vanuit economische motieven, capaciteits-motieven of zorginhoudelijke motieven. Wij kiezen voor de laatste benadering, waarin substitutiegezien wordt als het streven om patiënten van een minder naar een meer adequate zorgomgeving te brengen.

Een voorbeeld van een situatie waar patiënten per definitie geen adequate zorg ontvangen is het verkeerde bed. Verkeerde-bedproblematiek doet zich voor in het ziekenhuis wanneer een patiënt medisch specialistisch uitbehandeld is, maar om welke reden dan ook niet ontslagen kan worden (Hall \& Bytheway 1985). Doorgaans wordt in dergelijke gevallen een verpleeghuisindicatie aangevraagd (Fahrenfort \& Koning 1994), en wordt de wachttijd in het ziekenhuis doorgebracht. CVA-patiënten vormen bij uitstek een diagnosegroep waarin verkeerde-bedproblematiekzich voordoet (Hermans et al 1995, Lewis \& Purdie 1988, Wijdeven 1989). Onder invloed van de vergrijzing zal het aantal eerste CVA-gevallen toenemen (NWO 1992), en daarmee naar verwachting ook de verkeerde-bedproblematiek onder deze groep.

In een kleinschalig experiment in het verzorgingsgebied van het Maaslandziekenhuis Sittard-Geleen is gebleken dat thuiszorg voor verkeerde-bedpatiënten met CVA een haalbaar alternatief kan vormen voor een langer verblijf in het verkeerde bed indien in de thuissituatie iets meer dan de reguliere hoeveelheden zorg geboden kan worden (Hermans 1992). Zeven patiënten werden met hun instemming en die van hun familieleden vanuit het verkeerde bed naar huis ontslagen. De aan het project deelnemende zorgaanbieders hadden zich vooraf verplicht om aan de patiënten in de thuissituatie alle zorg te verlenen die noodzakelijk was om de doelstelling van het experiment te halen. Voor zes patiënten bestond de doelstelling uit het zo lang mogelijk continueren van het verblijf thuis, voor de zevende uit het overbruggen van de wachttijd voor opname in een verzorgingshuis. Bij beëindiging van het experiment, anderhalf jaar na ontslag uit het ziekenhuis, verbleven zes van de zeven patiënten nog thuis en was de zevende inderdaad opgenomen in een verzorgingshuis. Om de zorg in de thuissituatie gedurende langere tijd te bestendigen bleken de patiënten vooral een meer dan regulier beroep te doen op hulp door de gezinsverzorging. Voorts vond in alle gevallen dagbehandeling in een verpleeghuis plaats gedurende drie dagen 
per week. Huisarts en wijkverpleging besteedden aan deze patiënten niet meer zorg dan aan andere thuisverblijvende patiẻnten.

Om een indruk te krijgen van het aantal patiënten dat op deze wijze thuis verpleegd en verzorgd kon worden hebben wij een multidisciplinair panel gevraagd om de theoretische substitutiemogelijkheden te beoordelen van alle CVA-patiènten $(n=69)$ die in het jaar 1992 in het Maaslandziekenhuis te Sittard in het verkeerde bed terecht kwamen (Hermans et al 1996). Het panel bestond uit een huisarts, een hoofdwijkverpleegkundige, een hoofd zorg van een instelling voor gezinsverzorging en een hoofd verzorging van een verzorgingshuis. Elke patient werd op papier beschreven naar: algemene lichamelijke en psychische toestand (4-puntsschaal), de resterende medische, verpleegkundige en verzorgende hulpbehoefte en de kwaliteit van de relaties in het sociale netwerk. Thuiszorg werd door het panell als de meest vergaande vorm van substitutie opgevat. In gevallen waarin het panel thuiszorg niet haalbaar achtte (bijwoorbeeld vanwege het ontbreken van voldoende mantelzorg), werd zorg in een verzorgingshuis als volgende mogelijkheid in overweging genomen. Het panel kwam tot de conclusie dat 28 (34\%) van de 69 beoordeelde patiënten thuis of in een verzorgingshuis konden worden verpleegd of verzorgd als alternatief voor een langer verbliff in het verkeerde bed. Het paneloordeel was significant geassocieerd met de genoemde variabelen: vooral patiënten met weinig resterende zorgbehoefte, geen totale psychische of lichamelijke afhankelijkheid en patiènten die goede relaties hadden met personen in hun sociale netwerk werden substitueerbaar geacht.

In werkelijkheid werden slechts acht van deze patiënten (12\%) naar huis ontslagen, en geen enkele naar een verzorgingshuis.

Afgaande op het paneloordeel bestaat er dus een aanzienlijke kloof tussen het werkelijke en het theoretisch mogelijke ontslagpatroon van deze patiènten. Hoewel het panelonderzoek purr theoretisch was, gaan wij ervan uit dat de panelleden hun oordeel baseerden op een taxatie van de gang van zaken indien de betreffende patiẻnten werkelijk zouden worden ontslagen naar huis of naar een verzorgingshuis. Wij waren daarom geïnteresseerd in het beloop onder deze patiènten in de periode na ziekenhuisontslag. Het paneloordeel zou immers aan waarde winnen indien het niet alleen bruikbaar zou zijn om ad hoc te differentièren naar uitstroomcategorieën wit het ziekenhuis, maar indien er ook een relatie zou blijken te bestaan tussen deze uitstroomcategorieën en uitkomsten op lange termijn. Als termijn voor follow-up onderzoek wordt in de praktijk vaak gekozen voor één jaar. Er is, zeker in Nederland onder CVA-patiënten nog weinig onderzoek gedaan naar 
uitkomsten over een langere termijn dan een jaar. Er bestaan in Nederland dan ook weinig gegevens over langjarige overleving en over de ontwikkeling van 'care-pathways' over een langere periode. Wij kozen daarom als tijdstip voor follow-up onderzoek voor drie jaar na ziekenhuisopname. Als voornaamste lange termijn uitkomst kozen wij voor het al dan niet in leven zijn drie jaar na ziekenhuisopname. Tevens wilden wij onderzoeken of op basis van het paneloordeel, in combinatie met de lange termijn uitkomsten een indicatie kon worden verkregen van de omvang van de mogelijke substitutiewinst onder deze patiëntencategorie.

De vraagstelling voor dit artikel luidde daarom:

l Hoeveel patiënten van de oorspronkelijke populatie waren drie jaar na ziekenhuisopname nog in leven, en welke routes door het zorgsysteem hadden zij gedurende die drie jaar afgelegd?

2 Bestaat er een verband tussen het paneloordeel en uitkomsten op lange termijn?

3 Levert het paneloordeel in combinatie met de lange termijn uitkomsten een indicatie op van de omvang van de mogelijke substitutie onder verkeerdebedpatiënten met CVA gedurende de drie jaar volgend op ziekenhuisontslag?

\section{METHODE}

Van de oorsponkelijke populatie van 69 patiënten werden er vier geëxcludeerd: een patiënt was opgenomen in een instelling voor verstandelijk gehandicapten en drie waren verhuisd naar het buitenland en konden niet getraceerd worden. Hierbij was er éen met een gunstig paneloordeel over substitutie. Aldus waren 65 patiënten beschikbaar voor follow-up onderzoek: 22 mannen ( $34 \%$ ) en 43 vrouwen. De gemiddelde leeftijd was 76 jaar, en de gemiddelde verblijfsduur in het ziekenhuis was 72 dagen. Alle patiënten woonden voor hun ziekenhuisopname thuis of in een verzorgingshuis. De benodigde gegevens over het al dan niet in leven zijn, en de gang door het zorgsysteem, werden verzameld via de huisartsen of verpleeghuisartsen van de patiënten. Indien een patiënt was overleden werd geregistreerd waar dit was gebeurd: in het ziekenhuis, in een verpleeg- of verzorgingshuis of thuis. Voor de analyses werd het woonachtig zijn in een verzorgingshuis als thuis beschouwd omdat het in beide gevallen gaat om wonen in de matschappij.

Het bivariate verband tussen driejaars overleving en het paneloordeel werd getest met odds ratio's (OR) met $95 \%$ betrouwbaarheidsintervallen. Wij namen het paneloordeel als uitgangspunt van ons rekenmodel voor substi- 
tutie. In gevallen waarin dit oordeel positief was en de patiënt niet naar huis werd ontslagen, spreken wij van mogelijke substitutiewinst. Waar dit zich voordeed hebben wij de haalbaarheid van de substitutiewinst afhankelijk gesteld van de verblijfsituatie na drie jaar. Verbleef de patiënt na drie jaar thuis dan werd de haalbaarheid van substitutiewinst waarschijnlijker geacht; verbleef de patiënt na drie jaar niet thuis dan werd substitutiewinst minder waarschijnlijk geacht.

\section{RESULTATEN}

\subsection{DRIEJAARS OVERLEVING EN ROUTES DOOR HET ZORGSYSTEEM}

Drie jaar na ziekenhuisopname waren 26 patiënten $(40 \%)$ nog in leven. Hiervan woonden er $\mathbb{1}$ ( $17 \%$ van de totale populatie; $42 \%$ van de overlevenden) thuis of in een verzorgingshuis. De gang die de patiënten in de loop van de drie jaar maakten door het gezondheidszorgsysteem is weergegeven in overzicht 1 .

In overzicht 1 valt op dat er nogal wat variatie bestaat in de routes die patiënten aflegden. Het patroon dat het meest voorkwam is dat patiënten rechtsstreeks naar een verpleeghuis werden ontslagen en aldaar overleden. Onder de groep die rechtsstreeks naar een verpleeghuis werd ontslagen, was de sterfte na drie jaar het hoogst. Toch gingen er in de loop van de drie jaar na ziekenhuisontslag uit deze groep nog twaalf patiënten ( $25 \%$ ) naar een verzorgingshuis of naar huis.

\subsection{RELATIE TUSSEN HET PANELOORDEEL EN DRIEJAARS OVERLEVING}

Driejaars overleving was significant geassocieerd met een gunstig paneloordeel over substitutie. Van de 27 patiënten met een gunstig paneloordeel over substitutie waren er 16 (59\%) nog in leven, vergeleken met 10 van de $37(32 \%)$ met een ongunstig paneloordeel (OR: 3,8; 95\%-B.I.: 1,3-10,2).

\subsection{MOGELIJKE SUBSTITUTIEWINST}

In tabel 1 is weergegeven hoe het paneloordeel over substitutie zich verhoudt tot de situatie na drie jaar.

Verdere uitsplitsing van de gegevens levert aanwijzingen op waar substitutiewinst behaald zou kunnen worden. 

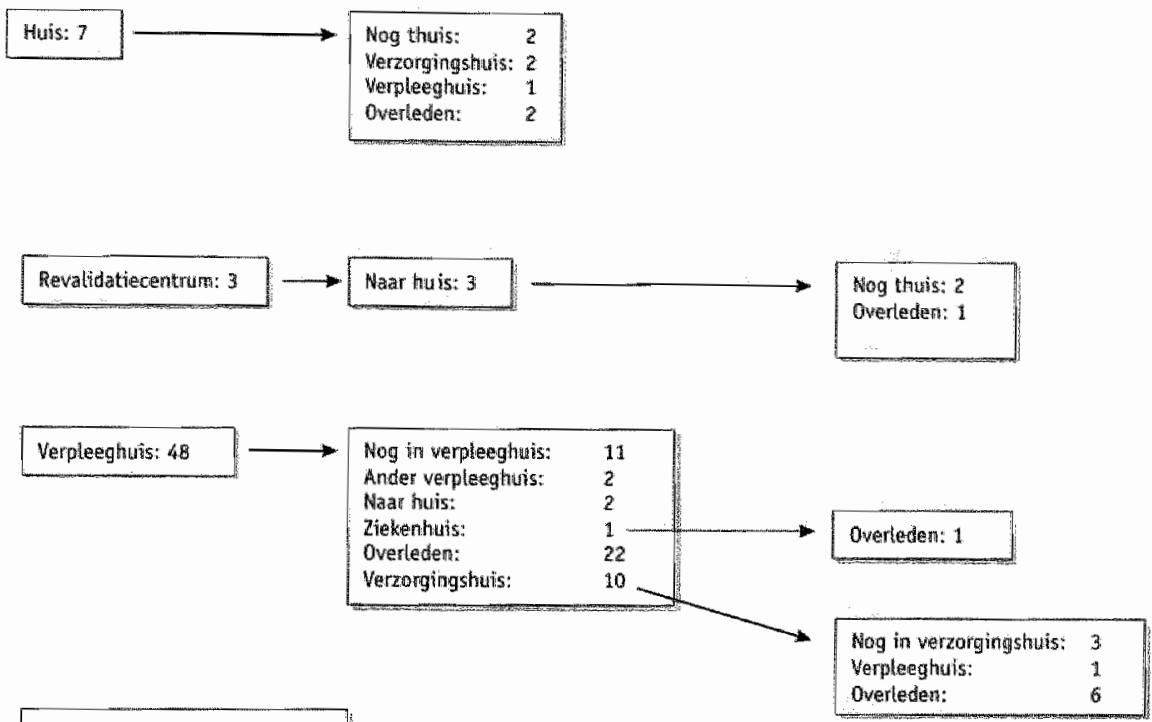

Owerleden in werkeende bed: 7

Als uitgangspunt van ons rekenmodel voor substitutie kozen wij de gevallen waarin het paneloordeel afweek van het feitelijk ontslag uit het ziekenhuis. Zoals uit tabel 1 blijkt is dit het geval in de regels 3, 4, 6 en 7 . In deze gevallen gaat het om patiënten die in werkelijkheid niet naar huis werden ontslagen, maar volgens het panel wel naar huis ontslagen hadden kunnen worden. Spontane substitutiewinst (patiënten die naar huis werden ontslagen ondanks een negatief paneloordeel over substitutie) kwam niet voor. In het onderstaande worden de patiënten uit de rijen $3,4,6$ en 7 in tabel 1 nader beschouwd.

Gemiddeld 10 maanden na ontslag uit het ziekenhuis keerden viff patiênten naar huis terug (regel 3). De mogelijke substitutiewinst bestaat uit de periode die zij na ontslag uit het ziekenhuis doorbrachten op een niet-thuis bestem- 
TABEL 1. GEMIDDELDE SUBSTITUTIEWIMST PER PATIËNT

\begin{tabular}{|c|c|c|c|c|}
\hline Categonie: & Regel & $\begin{array}{l}\text { Ontslagrichting vanuit } \\
\text { het ziekenhuis (N) }\end{array}$ & $\begin{array}{l}\text { Driejalars } \\
\text { owerleving }\end{array}$ & $\begin{array}{l}\text { Gemiddelde } \\
\text { substitutiewinst per } \\
\text { patient }\end{array}$ \\
\hline Positief parieloordeel en & 1 & Natar huis (4) & $3 \mathbf{a}$ & \\
\hline thus verbligvend of thwis & 2 & Naar huis (2) & Nee & \\
\hline overleden & 3 & Niet nalar huiss (5) & Ja: & 10 maanden \\
\hline$(N-14)$ & 4 & Nhet naar hulits $(3)$ & Nee & 5 maanden \\
\hline Positief paneloordeel en & 5 & Naar huis (1) & $\mathrm{Ja}$ & \\
\hline niet thuiss verblijvend of & 6 & Niet naar huis $(6)$ & Ja & Tussen 0 en 36 maanden \\
\hline $\begin{array}{l}\text { net thuts overleden } \\
(N=13)\end{array}$ & 7 & Niet naar huis $(6)$ & Hee & Tussen 0 en 15 maranden \\
\hline Negatief paneloordeel en & 8 & Niet naar huis (2) & Ja & \\
\hline $\begin{array}{l}\text { thuis verblijwend of thuis } \\
\text { overleden }(M-6)\end{array}$ & 9 & Niet naar huis (4) & Nee & \\
\hline Negatief paneloordeel en & 10 & Niet naar huis $(8)$ & Ja & \\
\hline $\begin{array}{l}\text { miet thuts verblijwend of } \\
\text { niet thuis overleden }\end{array}$ & 11 & Miet naar huis $(17)$ & Nee & \\
\hline$(N=25)$ & & & & \\
\hline
\end{tabular}

1 Paneloordeel over substitutie in combinatie met overlewing en verblijssituatie na drie jaar.

ming. Gezien het feit dat zij drie jaar na ziekenhuisontslag inderdaad thuis verbleven beschouwen wij deze 50 maanden als harde substitutiewinst. Drie patiënten keerden gemiddeld vijf maanden nadat zij vanuit het ziekenhuis naar een niet-thuis bestemming werden ontslagen naar huis terug en overleden daar binnen de periode van drie jaar (regel 4). De winst bestaat uit de periode die niet thuis werd doorgebracht. Omdat deze patiënten daadwerkelijk naar huis konden terugkeren, en daar bleven tot hun overlijden beschouwen wij ook deze 15 maanden als harde substitutiewinst.

Zes patiënten hadden een positief paneloordeel over substitutie, maar verbleven de volledige periode van 36 maanden tussen ziekenhuisontslag en de meetdatum op een niet-thuis bestemming (regel 6). Hoe lang deze patiënten eventueel thuis zouden hebben kunnen verblijven valt moeilijk te zeggen. De mogelijke substitutiewinst voor deze groep is dus niet hard, en ligt ergens tussen het minimum van 0 en het maximum van $(6 \times 36=) 216$ maanden. 
Zes patiënten keerden niet naar huis terug, en overleden op een niet-thuis bestemming, na een gemiddeld verblijf van 15 maanden (regel 7). De eventuele substitutiewinst is ook voor deze groep niet hard, en ligt ergens tussen het minimum van 0 en het maximum van ( $6 \times 15=) 90$ maanden.

Al met al leidt ons rekenmodel tot een harde substitutiewinst van $50+15=65$ maanden, en een zachte substitutiewinst van maximaal 216+90=306 maanden. Op basis van ruim 17.000 neurologische verpleegdagen in het Maaslandziekenhuis in 1992, en 1.261.115 neurologische verpleegdagen in algemene ziekenhuizen in heel Nederland (12), zou dit geëxtrapoleerd naar de Nederlandse situatie jaarlijks een harde besparing van 4.810 , en een zachte besparing van maximaal 22.644 patiëntmaanden betekenen in revalidatiecentra en -vooral-verpleeghuizen.

\section{DISCUSSIE}

Ons onderzoek verschilt van andere studies naar lange termijn uitkomsten onder CVA-patiënten door de samenstelling van de onderzoeksgroep. Alleen patiënten die in het ziekenhuis in het verkeerde bed hadden gelegen werden geïncludeerd. Voor zover kon worden nagegaan is een dergelijk onderzoek onder deze populatie nooit eerder uitgevoerd. Het is daarom niet verwonderlijk dat de percentages overlevenden en niet geïnstitutionaliseerd wonenden beduidend onder de bevindingen van ander onderzoek liggen. (Brocklehurst et al 1981, Wade et al 1984, Ahlsio et al 1984, Greveson et al 1991).

Van belang is de relatie die wij vonden tussen driejaars overleving en het paneloordeel over substitutie. Bedacht moet worden dat het paneloordeel werd gegeven zonder dat de panelleden de patiënten kenden, en terwijl de patiënten nog in het verkeerde bed lagen. Het is opmerkelijk dat een collectief van zorgverleners op een dergelijk vroeg moment in de zorgcarriére van de patiënten, en op basis van papieren en routinematig in elk ziekenhuis voorhanden informatie, een groep patiënten wist te onderscheiden die een significant hogere driejaars overlevingsratio had. Tegengeworpen zou kunnen worden dat het panel gevraagd was om te beoordelen welke patiënten naar huis of naar een verzorgingshuis ontslagen konden worden, en niet welke patiënten drie jaar later nog in leven zouden zijn. Het lijkt echter vanzelfsprekend dat de panelleden zich bij hun beoordeling van deze mogelijkheden hebben laten leiden door hun inschatting van de kansen van de patiênten op overleving en terugkeer naar huis. 
Wij wilden onderzoeken in hoeverre de door het panel theoretisch mogelijk geachte substitutie onderbouwd kon worden door het feitelijk beloop op langere termijn. Wij gaan ervan uit met dit onderzoek grofweg de onder-en bovengrens van de mogelijke substitutie in beeld te hebben gebracht. Het gehanteerde rekenmodel levert indicaties op dat in theorie een substantiële substitutie haalbaar is. De vraag is in hoeverre met name de zachte substitutiewinst in de praktijk te realiseren zal zijn. Het feit dat de betreffende patiënten in werkelijkheid niet naar huis terugkeerden zou een aanwijzing kunnen zijn dat dit patiënten zijn met complexe problematiek, zeer langdurige beperkingen en/of een zwakke mantelzorgsituatie. In dat geval zouden zij, indien zij naar huis zouden worden ontslagen, toch al vrij spoedig op verpleeghuisopname zijn aangewezen. Mogelijk ligt de werkelijk haalbare substitutie voor deze groep dichter bij het minimum dan bij het maximum. Om hier zicht op te krijgen zal vervolgonderzoek nodig zijn in praktische experimenten. Relevante factoren waaraan in dergelijk onderzoek aandacht zal moeten worden besteed zijn het ziektebeloop (recidive, comorbiditeit), aspecten van kwaliteit van leven, en de belasting van informele verzorgers, omdat hiervan de realiseerbaarheid afhangt van de zachte substitutie. Bedacht moet worden dat tegenover de substitutiewinst die behaald kan worden in verpleeghuizen en revalidatiecentra, een overeenkomstig verhoogde druk staat op de verzorgingshuizen en de thuiszorg. Zonder uitbreiding van capaciteit in deze zorg lijkt substitutie weinig kans van slagen te hebben.

\section{LITERATUUR}

1. Commissie Structuur en Financiering Gezondheidszorg. Bereidheid tot verandering. Den Haag 1987.

2. Commissie Modemisering Ouderenzorg. Ouderenzorg met toekomst. Den Haag, 1994.

3. Kemp A.A.M. de. Kosten en opbrengsten van substitutie in de zorg voor ouderen. Den Haag: Instituut Onderzoek Overheidsuitgaven, 1995.

4. Hall D., Bytheway B. The blocked bed; definition of a problem. Soc Sci Med 1985; 16 : 1985-91.

5. Fahrenfort M., Koning C.C. Onbekend maakt onbemind. Utrecht: NZI, 1994.

6. Hermans E. Anten H.W.M. Diederiks J.P.M., Philipsen H., Beeren H.W.J.M. Patientkenmerken met voorspellende betekenis voor 'verkeerde-bedproblematiek' op de 
neurologische afdeling van een algemeen ziekenhuis. Ned Tijdschr Geneeskd 1995; 139: 890-4.

7. Lewis H., Purdie G. The blocked bed: a prospective study. NZ Med 1988; 101; 575-6.

8. Wijdeven C.F.F. De verkeerde bed problematiek: een onderzoek naar de omwang wan de verkeerde bed problematiek en naar factoren die hierop van invloed zijn [afstudeerscriptie Gezondheidswetenschappen]. Maastricht: Rijksuniversiteit Limburg, 1989.

9. NWO/Gebied Medische Wetenschappen. Wetenschappelijk Kaderprogramma voor het Nederlands Hersendecennium. Den Haag, 1992.

10. Hermans E. Project Integraal Regionaal; zorgvernieuwing in de Westelijke Mijnstreek. Medisch Contact 1992; 47: 435-8.

11. Hermans E.,Anten H.W.M., Diederiks J.P.M., Philipsen H., Hameleers B „ Sikkes-Mekel O., Schepers A. CVA-patiënten in het 'verkeerde bed'; een onderzoek naar theoretische alternatieven. Tijdschr Soc Gezondheidsz 1996; 74: 96-100.

12. Anonymus. De intramurale gezondheidszorg in cijfers. Utrecht: NZI, 1994.

13. Brockdehurst J.C., Morris P., Andrews K., Richards B., Laycock P. Social effects of stroke. Soc Sci Med 1981; 15A: 35-9.

14. Wade D.T., Skilbeck C.E., Wood V.A., Langton Hewer R. Long-term survival after stroke. Age and Ageing 1984; 13: 76-82.

15. Ahlsiö B., Britton M., Murray V., Theorell T. Disablement and quality of life after stroke. Stroke 1984; 15: 886-90.

16. Greveson G.C., Gray C.S., French J.M., James O.F.W. Long-term outcome for patients and carers following hospital admission for stroke. Age and ageing 1991; 20: 337-44. 
HOOFDSTUK 7

Use of care by home-dwelling stroke patients during 3 years following hospital discharge

E. Hermans, H.W.M. Anten, J.P.M. Diederiks, H. Philipsen

Published in: Scandinavian Journal of Caring Sciences 1998; 12: 186-190 


\section{ABSTRACT}

Of 82 stroke survivors who had been discharged home from hospital, 49 were still living at home after a three year period. Thirty-three of these patients formed the population of the present study into the use of care at home. Sixty-one \% had received professional care and $88 \%$ had received family care. Although the overall functional status indicated only mild handicap, after three years patients still reported a large number of disabilities and problems. The average weekly amount of family care was 37 hours, and many family carers experienced a high burden of care and had emotional problems coping with the patients" disabilities. Concerning factors related to the use of care, in spite of the relatively small number of study patients, some interesting hypotheses could be advanced. 


\section{INTRODUCTION}

Stroke patients are generally confronted with several disabilities and handicaps, and, consequently, with a substantial burden of illness. This situation prompts the need for care from several sources, professional as well as informal. After a patient's discharge from hospital, different care trajectories may emerge. The patient may be discharged to a rehabilitation unit, nursing home, home for the aged or to his or her own home. The trajectories may also consist of combinations of these discharge destinations, in different orders. As yet, little is known about the variability of these trajectories and the related use of care over longer periods of time. Two main patterns, however, may be assumed to exist: patients discharged to nursing homes and remaining there, and patients discharged home, directly or indirectly. Once the patients arrive home, their disabilities become manifest not only to themselves, but also to spouses or family members.

This retrospective pilot study focuses on patients discharged to their homes. It is well known that most of the care at home is given by informal carers and that the burden of the care weighs heavily on them (Anderson 1987, Anderson 1995, Levin \& Idler 1981). A larger study among hospitalized stroke patients (Hermans et al 1995) in the Netherlands provided us the opportunity to conduct this pilot follow-up study to gain more insight into the use of care by stroke patients over a period of three years after discharge from hospital. It was expected that:

- patients who were discharged from hospital with a paresis or speech disturbances would receive more care at home than others;

- the overall use of care would be influenced by the disabilities the patients experienced as a result of their stroke, as well as by their co-morbidity and dependency in ADL;

- in cases in which the principal family carers have emotional problems with the patients' disabilities, or the sheer amount of family care necessary makes high demands on their time, or family carers experience a high burden of care, the use of professional care would be more likely.

These expectations led to the following questions we aim to answer:

1 What care did the patients receive after discharge from hospital?

2 What disabilities occur in home-dwelling stroke patients 3 years after discharge from hospital?

3 To what degree do the principal family carers have emotional problems with the patients' disabilities and to what degree do they experience the burden of family care? 
4 What factors are related to the use of professional care, family care and the burden of family care?

\section{PATIENTS AND METHOD}

The base population was a cohort consisting of all patients hospitalized for acute stroke during the year 1992 in the Maasland Hospital Sittard-Geleen in the Netherlands $(\mathrm{n}=232)$.

Stroke was specified according to the World Health Organization's definition (1989). This definition excludes Transient Ischaemic Attack, but it includes Reversible Ischaemic Neurological Deficit. Patients with RIND, however, were excluded from the study, since they -by definition- do not show any neurological symptoms after one week. In the present study all patients $(n=49)$ fullfilling the following criteria were included. They had to

a have been discharged from hospital directly to their own homes,

b be alive three years after hospital discharge,

c be living at home three years after hospital discharge, and

d have at least one identifiable familly carer.

The trajectories of all patients in the cohort are shown in table 1.

From our own data and, if we were uncertain from the GP's, we gathered information about the patients' being alive and about the identity of the principal family carers. Patients and their principal family carers were invited by letter for an interview. If no reaction was received within three weeks, a reminder was sent. In 16 cases $(33 \%)$ we got no reaction at all on our (repeated) request for cooperation, or cooperation was refused, so that 33 patients were eligible for follow-up. Interviews took place in the course of the year 1995, three years after discharge of each patient from hospital. Patients and family carers were interviewed separately in the patients' homes by the first author. The average duration of the interviews was about 1,5 hours per patient-system.

As independent variables, influencing the use of care and the burden of family care, we chose four objective indicators of illness seriousness: concomitant disease, functional state, and paresis and speech disorders at hospital discharge. We also chose two subjective factors: the family carers' problems in accepting the patients' disabilities, and the patients burden of illness.

The use of professional care was measured by asking patients if they at any time in the past three years had had help from a health care professional. The use of family care was measured by asking the principal family carers if they 
Use of care by home-dwelling stroke patients during 3 years following hospital discharge

\section{TABLE 1. PATIENT TRAJECTORIES}

Total number of stroke patients admitted

to the hospital during the year 1992:

RIND-diagnasis:

Died in hospital during the acute phase:

Transferred to other department or ather hospital during the acute phase:

Total:

Number of patients of which medical hospital-treatment could be completed:

Of these 160 patients 69 became bed blockers, which means that they -by various reasons-couldn't be discharged within 10 days after completing medical hospital treatment.

The other 91 patients could be discharged to:

Their own homes:

Home for mentally handicapped:

Nursing home:

Rehabilitation unit:

Home for the elderly:

Place of residence 3 years after hospital discharge of the 82 patients who could be discharged home:

Home for the elderly:

Nursing home:

Died:

Could not be traced:

Still staying at home: 
had given or still gave their relatives any help as a result of stroke, and what was the average weekly amount of this help. No specifications were made into the nature of this help. Professional care was divided into home care (district nursing and home help) and rehabilitation (day attendance in a nursing home or ambulant physical therapy, speech training or occupational therapy). Medical care was not taken into account because of its availability on request. The burden of caregiving was measured by asking the principal family carers if they experienced any burden. Functional status was measured by the Barthel ADL Index, a valid (Wade \& Langton-Hewer 1987) and reliable (Collin et al 1988) instrument which gives scores between 0 and 20. A score of 20 implies functional independence, but not necessarily normality. Scores from 15-19 indicate mild handicap, 10-14 moderate, 5-9 severe, and 0-4 very severe handicap (Legh-Smith et al 1986). A paresis at hospital discharge was assumed to be present at a score of $>2$ on the MRC Index (Oosterhuis 1995). Speech disorders included aphasia and dysarthria. The data on paresis and speech disorders were taken from the medical records in the hospital. The family carers' problems accepting the patients' disabilities were measured by asking them if they actually experienced emotional problems in living with their disabled relatives. The burden of ilness was measured using a scale to be described in the results section. In the correlational analysis the variables were dichotomized around the mean. In the analysis Phi-coefficients were used. No multivariate analysis was performed due to small numbers

\section{RESULTS}

\subsection{MATN CHARACTERISTICS OF THE STUDY POPULATION}

The study population consisted of 17 male and 16 female patients. The average age was 63 years (range: $41-85$ ). The principal family carers were 22 women and 11 men. In 28 cases the principal family carer was the patient's spouse, in 2 cases the carer was the patient"s daughter, in one case the granddaughter, and in one other case she was the patient's sister. One patient was a nun, being cared for by a another nun. The average duration of stay in hospital was 26 days. Nineteen patients ( $58 \%$ ) had been discharged from hospital with paresis and $13(40 \%)$ with speech disorders. 
TABLE 2. COMPLEXITY, OURATION AND INTENSITY OF PROFESSIONAL CARE

\begin{tabular}{llll}
\hline Type of care & Median duration & Range $^{1}$ & $\begin{array}{l}\text { Average number of } \\
\text { contacts/week }\end{array}$ \\
\hline Only home care $(n=3)$ & 10 & $2-100$ & 3 \\
Only rehabilitation $(n=14)$ & 23 & $9-126$ & 2.5 \\
$\begin{array}{l}\text { Combination of home care and } \\
\text { rehabilitation }(n=3)\end{array}$ & 90 & $5-108$ & 2 \\
\hline
\end{tabular}

${ }^{1}=$ in weeks

\subsection{PROFESSIONAL AND FAMILY CARE}

Twenty patients $(61 \%)$ had received professional care since their discharge from hospital. Seventeen patients ( $52 \%$ ) received rehabilitation; 5 (15\%) had day attendance in a nursing home, $11(33 \%)$ had ambulant therapy and 1 patient $(3 \%)$ had both day attendance and ambulant therapy. Six patients (18\%) received home care; $3(9 \%)$ had district nursing, $2(6 \%)$ had home help and $1(3 \%)$ had both nursing and home help. Fourteen patients (42\%) had rehabilitation only, 3 (9\%) only had home care, and also $3(9 \%)$ had both rehabiliation and home care. Thirteen patients (39\%) had no professional care at all. All professional care was given in uninterrupted periods of time directly following hospital discharge. The average duration of professional help was 8 months per patient. Only one patient had professional care during the total 3-year period. For patients who had home care only, the median duration of care was 10 weeks, and for those who had a combination of home care and rehabilitation, the median duration was 90 weeks (table 2).

A vast majority ( $88 \%$ ) of the family carers reported giving family care as a result of the patients' stroke. The other four (all being the patients' spouses) reported no family care at all. Three of the four patients concerned had no professional care either. The average amount of family care given was 37 hours a week (range 1-119 hours). Spouses gave more family care (average 51 hours) than children (avarage 10 hours).

Eleven family carers ( $33 \%$ ) said they experienced a high burden of family care and 11 (33\%) said they had emotional problems in accepting the patients' disabilities. 


\subsection{DISABILITIES EXPERIENCED BY PATIENTS}

Three years after hospital discharge most patients $(79 \%)$ experienced mobility problems; about one third reported speech problems. Seventeen patients $(52 \%)$ said they were in treatment for concomitant disease. Twenty-six patients $(79 \%)$ reported disturbed emotions as a problem. They generally described an inability to control their emotions since their stroke. Ten patients $(30 \%)$ said they had experienced symptoms since their discharge from hospital which made them think of recurrent stroke, such as severe dizziness or transient loss of function. The average score on the Barthel ADL-Index was 17 . Two patients (6\%) were severely disabled, 16 $(48 \%)$ were mildly disabled, and $11(33 \%)$ were independent (score 20$)$ in ADL. Table 3 summarizes the problems experienced by the patients.

Six items mentioned in table 3 formed a scale with high internal consistency (Cronbach's Alpha: 0.71): speech problems, experiencing 'recurrent stroke' symptoms, emotional changes, less going out, decline in receiving vistits, and experiencing lack of knowledge about stroke (average score on this scale: 2.7; S.D.: 1,8 ). This scale, dichotomized around the mean, was included in the analys.s as a separate variable 'burden of illness'.

\subsection{FACTORS RELATED TO CARE AND CAREGIVER'S BURDEN}

Three dependent variables were included in the correlational analysis: the use of professional care (yes/no), the amount of family care (below or equal to/above average) and the burden of family care (yes/no). The independent variables included four objective indicators of the illness seriousness: concomitant disease (yes/no), the score on the Barthel-Index (below or equal to/above average), paresis at hospital discharge (yes/no), and speech disorders at discharge (yes/no); and two subjective factors: the family carers' problems in accepting the patients' disabilities (yes/no) and the patients' burden of illness (below or equal to/above average) (table 4).

From table 4 it emerges that receiving professional care is significantly related to objective illness and dependency factors, i.e. co-morbidity and an unfavourable score on the Barthel ADL Index. The amount of family care is not related to objective illness seriousness but mainly to the patients' burden of illness. Furthermore it appears that the burden of family care is influenced by the amount of family care and by the family carers' problems accepting the patients' disabilities. In cases where the family carers do not not easily accept the patients' disabilities, the use of professional care is more likely. A separate 
BLE 3. PROBLEMS EXPERIENCED BY PATIENTS

\begin{tabular}{|c|c|}
\hline in treatment for concomitant disease & 52 \\
\hline < average score on Barthel ADL Index & 58 \\
\hline recurrent strake symptoms ${ }^{2}$ & 30 \\
\hline moving & 79 \\
\hline seeing & $3: 2$ \\
\hline reading & 37 \\
\hline speech $^{2}$ & 32 \\
\hline disturbed emotions & 79 \\
\hline lack of knowledge on stroke & 53 \\
\hline declining to receive visits ${ }^{2}$ & 26 \\
\hline less going out $t^{2}$ & 53 \\
\hline
\end{tabular}

TABLE 4. CORRELATIONS

\begin{tabular}{lllllll}
\hline $\begin{array}{l}\text { Paresis } \\
\text { at disch. dist. } \\
\text { disch. }\end{array}$ & $\begin{array}{l}\text { lonco- } \\
\text { mit. } \\
\text { disease }\end{array}$ & score & $\begin{array}{l}\text { High } \\
\text { burden } \\
\text { of illn. }\end{array}$ & $\begin{array}{l}\text { Probl. } \\
\text { with } \\
\text { handic. }\end{array}$ & $\begin{array}{l}\text { Profess. >avg } \\
\text { care }\end{array}$ & $\begin{array}{l}\text { fam. } \\
\text { care }\end{array}$ \\
\hline
\end{tabular}

\section{Paresis at disch $\mathrm{x}$}

Speech dist. disch. 0.10

Concomit. disease

$0.64^{2}$

$x$

Barthel score

0.13

$0.17 \quad x$

High burden illn. 0.32

0.44

$0.14 x$

Problems with

handicaps

$0.20 \quad 0.20$

0.30

0.02

0.26

$x$

Profess. care

$0.18 \quad 0.26$

0.33

$0.350 .33 \times$

$>$ avg fam. care

$0.10 \quad 0.32$

$0.46^{1}$

$0.61^{2}$

0.04

$0.57 x$

High burden care

0.09

0.14

0.33

$0.41^{1}$

0.18

$0.18 \quad x$

${ }^{1} p<0.05 ;^{2} p<0.01$

0.2

0.35

0.38

$0.45^{1}$

$0.31 \quad 0.60^{2}$ 
analysis showed that the non-acceptance of the patients' disabilities seems to be mainly influenced by one item from the burden of ilness scale: the patient's persistent speech problems. We found no relation between professional care and a paresis or speech disturbances at hospital discharge.

\section{DISCUSSION}

In our study population about $60 \%$ of the patients received professional care over a three year period. Whether this percentage is high or low is ultimately a matter of comparison. Percentages of patients using day hospitals and day centers vary between 10 and $18 \%$ (Legh-Smith et 11986 , Victor \& Vetter 1985, Ebrahm \& Nouri 1987. Greveson et al 1991, Williams \& Fitton 1991, Thorngren \& Westling 1991), compared to $21 \%$ in our study. In a recent scandinavian study the proportion of patients having rehabilitation was the same as in our study: about $40 \%$ (Widen Holmqvist et al 19996). Percentages in our study using district nursing $(11 \%)$ and home help (13\%) are lower than those found in other studies: 15 to $31 \%$ district nursing (Legh-Smith et al 1986, Ebrahim \& Nouri 1987, Greveson et al 1991) and 18 to $37 \%$ home help (Legh-Smith et al1986, Ebrahim \& Nouni 1987, Greveson et al 1991, Williams \& Fitton 1991, Thorngren \& Westling 1991). Two studies report proportions using district nursing of about $50 \%$ (Widen Holmquist et al 1996, Pedro-Cuesta 1993). Two cautionary notes are warranted. First, there are differences in the health care systems between the Netherlands and other countries. Secondly, since we are dealing with patients who were directly discharged from hospital to their homes, the study population is a favourable selection of all patients discharged from the hospital. The rather favourable profile of our population on the Barthel Index is congruent with this observation.

A large proportion of the care received by the patients in our study is provided by persons from within the patient's informal network: for an average of 37 hours weekly. This may even be an underestimation of the real proportion of family care given, because we found that family carers, especially spouses, were inclined not to include help which was already given before the patients' stroke. Furthermore, the burden of family care was substantial. Because of the small number of patients in our study we made only a global analysis, and we did not investigate what specific needs were associated with the burden of care. One can easily imagine that caregiving at night and helping with toileting, for instance, would be regarded as heavy tasks, increasing the 
burden of caregiving. To get more insight into these factors and to examine changes over time in the need for care, new longitudinal studies on this subject have to be done.

An interesting finding is that receiving professional care is primarily connected with objective illness factors and not with subjective factors in the family system, with the exception of the family carers' problems in accepting the patients' disabilities. As the difficulty of accepting the disabilities is related to the use of professional care, it may be hypothesized that this factor works as a trigger to call for professional care. The fact that this difficulty seems mainly rooted in the patients' speech problems adds to the plausibility of this hypothesis. However, other studies show that a cry for help from the informal network is not easily made public (17). Further investigations are needed to determine whether the informal carers" emotional problems in dealing with the patients' disabilities is a decisive factor in this respect. One of the practical implications of our study is that home care professionals, such as district nurses should be sensitive to signals of overload from family carers. The limited number of patients in our study of course precludes definitive conclusions. Nevertheless, several important hypotheses on the factors related to the use of professional care, and to the caregivers' burden, can be advanced:

- It is primarely the global (concomitant disease, Barthelscore), and not the more specific illness and dependency variables (mobility and speech problems) which are related to the use of professional care.

- Professional care on the one hand, and family care on the other, function almost as separated circuits. The informal caregivers' emotional problems in accepting their relatives' disability seems the only connection between them.

These hypotheses should be tested in new studies.

\section{REFERENCES}

1. Anderson C. A population-based assessment of the impact and burden of caregiving for long-term strake survivors. Stroke 1995; 26: $843-849$.

2. Anderson R. The unremitting burden on carers. Br Med J 1987; 294: 73-4.

3. Levin L., Idler E. The hidden health care system: mediating structures and medicine. Cambridge, Massachussetts: Ballinger, 1981.

4. Hermans E., Anten H.W.M., Diederiks J.P.M., Philipsen H., Beeren H.W.J.M. Patientkenmerken met voors pellende betekenis voor 'verkeerde-bedproblemattek' op de 
neurologische afdeling van een algemeen ziekenhuis. Ned Tijdschr Geneeskd 1995; 139: 890-894.

5. WHO Task Force on Stroke and other Cerebrovascular Disorders. Recommendations on stroke prevention, diagnosis and therapy. Stroke $1989 ; 20: 1407-1431$.

6. Wade D.T., Langton $*$ Hewer R. Functional abilities after stroke: measurement, natural history and prognosis. J. Neurol Neurosurg Psych 1987; 50: 177-182.

7. Collin C., Wade D.T., Davies $S$. Horne V. The Barthel Index: a reliability study. Int Disabil Studies 1988; 10:61-63.

8. Legh-Smith I.,Wade D.T., Langton-Hewer R. Services for stroke patients one year after stroke. J Epidemiology Comm Health 1986; 40: 161-165.

9. Oosterhuis H.J.G.H. Klinische neurologie (Clinical neurology). Houten/Diegem: Bohn Stafleu Van Loghum, 1995.

10. Victor C.R., Vetter N.J. Use of community services by the elderly 3 and 12 months after discharge from hospital. Int Rehabil Med 1985: 7:56-59.

11. Bbrahim S. Nouri F. Caring for stroke patients at home. Int Rehabil Med 1987; 8 : $171-173$.

12. Greveson G.C., Gray C.S., French C.M., James O.F.W. Long-term outcome for patients and carers following hospitall admission for stroke. Age and Ageing 1991:20:337-344.

13. Williams E.I., Fitton F. Use of nursing and social services by elderly patients discharged from hospital. Br J Gen Practice 1991; 41: 72-75.

14. Thorngren M., Westling B. Utilization of health care resources after stroke. Acta Neurol Scand $1991 ; 84: 303-310$.

15. Widen Holmqvist L., Pedro Cuesta P. de, Möller G., Holm M., Siden A. A pilot study of rehabilitation at home after stroke; a health-economical apprassal. Scand J Rehab Med $1996 ; 28: 9 \times 18$.

16. Pedro Cuesta P. de, Sandström B., Holm M., Stawiarz L. Widen Holmqvist L. Bach-y-Rita P. Stroke rehabilitation: identification of target groups and planning data. Scand J Rehab Med 1993; 26;107 116.

17. Schure L.M. Stroke-provoked consequences for caregivers: results of a Dutch study. In: Caregivers of stroke patients: proceedings conference 3 May 1994. The Hague: Netherlands Heart Foundation, 1994. 
HOOFDSTUK 8

\section{Beschouwing}

\section{DE METHODE}

Zoals in hoofdstuk 1 is beschreven, was het basismateriaal van de beschreven onderzoeken afkomstig van het project Integraal Regionaal in het verzorgingsgebied van het Maaslandziekenhuis Sittard-Geleen. Hoewel dit project geen wetenschappelijk vertrekpunt kende is na afloop van het project toch besloten om de resultaten te beschrijven in een aantal wetenschappelijke publicaties. Deze vorm van wetenschapstoepassing bleek te leiden tot heldere antwoorden op de gestelde vragen. Het aantal beschikbare variabelen was voldoende, en de kwaliteit van de variabelen was goed. Bovendien was de omvangrijke onderzoekspopulatie helder en goed beschreven. Op grond van deze vaststellingen is besloten om drie jaar na ziekenhuisopname vervolgonderzoek te entameren onder patiënten uit de oorspronkelijke onderzoekscohort. Ook dit onderzoek heeft heldere resultaten opgeleverd voor de betreffende populatie.

In het onderzoek zijn alle patiënten met CVA betrokken die in het onderzoeksjaar 1992 in het Maaslandziekenhuis werden opgenomen. Doordat het Maaslandziekenhuis het enige ziekenhuis is in de regio Westelijke Mijnstreek, levert het onderzoek een zeer representatief beeld op van de situatie in deze regio. Het onderzoek is hierdoor tegelijkertijd echter ook een één-praktijkonderzoek. Drie neurologen uit een en dezelfde praktijk beslisten over de diagnose en het aanwijzen van de verkeerde-beddagen. Hoewel dit op zich een beperking vormt, staat hier tegenover dat een rondvraag onder andere neurologen in Nederlandse ziekenhuizen uitwees dat zij op dezelfde wijze bepaalden wanneer sprake was van een verkeerd bed. Het aantal geregistreerde verkeerde-beddagen in de Westelijke Mijnstreek mag, mede gezien de duur van het onderzoek, representatief geacht worden voor de regio. Aan de op grond hiervan gemaakte schatting van het aantal verkeerde-beddagen op landelijke schaal moet echter vooralsnog niet meer dan indicatieve betekenis toegekend worden. De bezettingsgraad van zieken-, 
verpleeg-en verzorgingshuizen, en daarmee de omvang van de problematiek kent aanzienlijke regionale verschillen.

De mogelijkheden om CVA-patienten die in het verkeerde bed terecht kwamen thuis of in een verzorgingshuis te verplegen als alternatief voor een langer verblijf in het verkeerde bed (substitutie) werden in kaart gebracht door alle verkeerde-bedpatiënten met CVA die in 1992 in het ziekenhuis voorkwamen, op hun substitutiemogelijkheden te laten beoordelen door een panel van zorgverleners. Een sterk punt is dat dit panel een vaste samenstelling kende gedurende de volledige looptijd van het onderzoek; het panel bestond uit zorgverleners uit de regio waar het onderzoek werd gehouden. Maatgevend was voor ons het consensus-oordeel van de vier niet klinische zorgverleners uit het panel omdat deze zorgverleners een goed zicht hadden op de mogelijkheden van de thuiszorg en de verzorgingshuizen in de regio.

Een belangrijke vraag was of de met het consensus-oordeel van het panel vastgestelde substitutiemogelijkheden meer dan locale betekenis hadden. Deze vraag werd onderzocht met behulp van een groter panel, dat voor een belangrijk deel uit zorgverleners van buiten de regio was samengesteld. Dit tweede panel bleek de beoordelingsresultaten van het oorspronkelijke panel in bevredigende mate te kunnen reproduceren. Wij menen dan ook dat hiermee de stap van locale naar meer universele kennis op verantwoorde wijze genomen is.

Wij zijn van mening dat de panelmethode voor het beoordelen van de substitutiemogelijkheden van de onderzochte patiëntenpopulatie zeer geschikt is. Bij deze beoordeling speelt het met beoordelingvraagstukken in het algemeen verbonden probleem van de intersubjectiviteit een belangrijke rol omdat zorgverleners van diverse disciplines uiteenlopende afwegingen maken. Als het gaat om verkeerde-bedpatiënten met CVA kan multidisciplinair overleg worden aanbevolen als mogelijkheid om tot consensus te komen. Niet duidelijk is welke factoren welke rol spelen in de afwegingsprocessen van de verschillende zorgverleners, al komen uit het onderzoek aanwijzingen dat adequate informatie over de mantelzorgsituatie de afwegingswerschillen kan reduceren. Nader onderzoek hiernaar moet dan ook worden aanbevolen.

Omdat het panel de theoretische substitutiemogelijkheden van de patiënten onderzocht, spreekt het vanzelf dat de resultaten op hun praktijkwaarde getest moeten worden.

Met het paneloordeel was een indicatie gegeven van het aantal substitueerbare patiënten. In het vervolgonderzoek is een poging gedaan om de omvang 
van de hiermee gepaard gaande substitutieuwinst te schatten aan de hand van uitkomsten na 3 jaar. Wij gaan ervan uit hiermee de grenzen van de substitutiemogelijkheden voor deze groep grofmazig in kaart te hebben gebracht. Geen rekening kon hierbij gehouden worden met variabelen als het ziektebeloop, comorbiditeit en de invloed van de houding van familiezorgers op de terugkeer naar de eigen woon-en leefsituatie, in verband met het ontbreken van continue registratie van deze variabelen. Inzicht in deze factoren kan de onderzoeksresultaten waarschijnlijk verder verfijnen, zodat dit onderzoek moet worden aanbevolen.

Ten aanzien van het zorggebruik in de thuissituatie door patiënten die niet in het verkeerde bed hadden gelegen, gelden de grote uitval en de daardoor resterende kleine onderzoeksgroep als beperking. Deze patiênten werden drie jaar na hun ziekenhuisopname schriftelijk benaderd om deel te nemen aan vervolgonderzoek. Geconcludeerd kan worden dat deze wijze van benadering niet de juiste methode is om onder deze populatie een bevredigende response te verkrijgen.

Niettemin bleek het mogelijk om enkele interessante hypothesen te formuleren die als uitgangspunt kunnen dienen voor vervolgonderzoek. De resultaten zullen dan ook in onderzoek op een omvangrijker dataset bevestigd moeten worden.

\section{DE PRAKTIJK}

De voornaamste betekenis voor de praktijk is dat het mogelijk lijkt om de verkeerde-bedproblematiek onder CVA-patiénten deels te reduceren via substitutie naar de thuiszorg of naar zorg in verzorgingshuizen, en op deze wijze ruimte te creëren in revalidatiecentra en -vooral- in verpleeghuizen. Van belang is dat van de door het panel geïdentificeerde groep substitueerbare patiënten er na drie jaar significant meer nog in leven bleken te zijn dan van de overigen. Dit betekent dat voor deze groep daadwerkelijke terugplaatsing naar huis of naar een verzorgingshuis langerdurende positieve effecten kan hebben als het gaat om kwaliteit van leven.

Voor de praktische uitvoering van de panelmethode is het van belang om te benadrukken dat het panel de groep substitueerbare patiënten kon selecteren met behulp van informatie die in ziekenhuizen routinematig voorhanden is; het betrof voornamelijk gegevens over zorgbehoefte en afhanke- 
lijkheid. Hiervoor hoeven dus geen nieuwe administratieve procedures te worden opgezet.

De meningen van de individuele panelleden ten aanzien van substitutie bleken voor het merendeel wan de gescreende patiënten (nagenoeg) overeen te stemmen. Over een minderheid, circa derde deel van de totale patiëntengroep, liepen de meningen hoofdzakelijk uiteen. Voor de praktijk betekent dit dat een eerste selectie op substitueerbaarheid gemaakt kan worden door én professional, ongeacht diens herkomst of discipline. Voor de resterende groep kan op grond van de resultaten multidisciplinair overleg als methode worden aanbevolen. Dergelijk overleg voor deze patiëntengroep is in veel regio"s nog onbekend. In het project Integraal Regionaal is geëxperimenteerd met het voeren van dergelijk overleg. Er was een situatie gecreëerd waarin dit overleg zich vrij kon ontwikkelen, en niet gehinderd werd door in de alledaagse praktijk bestaande belemmeringen als capaciteitsproblemen en ideologieverschillen. Wij hebben de indruk dat extramurale zorgverleners voorafgaand aan het experiment vrijwel geen zicht hadden op de zorgbehoeften van deze patiëntengroep. Van de andere kant hadden intramurale zorgverleners weinig zicht op mogelijkheden en onmogelijkheden van de thuiszorg. Al werkende namen deze ongelijkheden af en ontwikkelde men een vorm van werkcoördinatie die tot alleszins bevredigende resultaten leidde. Uit het onderzoek blijkt dat het belangrijk is dat professionals van niet klinische disciplines goed vertegenwoordigd zijn in dergelijk multidisciplinair overleg over het zorgtraject van CVA-patiënten. Dit geld zeker wanneer de thuiszorg en de verzorgingshuizen een expliciete plaats innemen in dit zorgtraject. Als vertegenwoordigers van klinische disciplines in dergelijk overleg zijn op grond van de resultaten van ons onderzoek vooral verpleeghuisartsen gekwalificeerd.

Het lijkt overigens in de praktijk niet waarschijnlijk dat zorgaanbieders staan te trappelen om de theoretisch mogelijke verschuivingen in patiëntenstromen daadwerkelijk te realiseren zolang de financiële regelgeving hierop niet is toegesneden. Een aanwijzing in deze richting werd kort na afloop van het project Integraal Regionaal verkregen. Projectparticipanten hadden al snel de neiging om, ondanks de gebleken gunstige theoretische substitutiemogelijkheden terug te vallen op de oude posities. De thuiszorg staat onder grote druk, en een routewijziging van verkeerde-bedpatiënten in de richting van de thuiszorg zal deze druk nog verder opvoeren. Het is dan ook waarschijnlijk niet toevallig dat de vertegenwoordiger van de gezinsverzorging in het panel zich het meest afwijzend toonde ten opzichte van thuiszorg voor 
deze patiëntengroep. Het was in de pilotfase van Integraal Regionaal immers gebleken dat de gezinsverzorging de discipline was die de zwaarste bijdrage zou moeten leveren om thuiszorg mogelijk te maken. Tussen het individuele oordeel van het panellid van de gezinsverzorging en het consensus-oordeel van de vier niet-klinische zorgverleners bestaat overigens een substantieel verschil. Kennelijk had het overleg in het panel ertoe geleid dat de gezinsverzorging in een aantal gevallen minder sceptisch tegen de mogelijkheid van thuiszorg aankeek. Capaciteitsuitbreiding buiten het ziekenhuis is echter hoe dan ook een 'conditio sine qua non' om dit type substitutie te realiseren. Bij daadwerkelijke thuisplaatsing van deze patiënten zal er rekening mee gehouden moeten worden dat deze zorg zwaar is en veel vergt van de informele zorgers. Voor overbelasting van partners en andere familieleden zal door de professionele zorg dan ook goed gewaakt moeten worden, temeer daar signalen van overbelasting niet makkelijk worden gegeven en vaak slecht worden herkend. Verontrustend is in dit verband het feit dat uit het onderzoek bleek dat professionele thuiszorg en informele zorg teveel als gescheiden circuits functioneren, een bevinding die niet direct wijst op het bestaan van veel coördinatie.

\section{DE THEORIE}

Retrospectief is een poging gedaan om de bevindingen van het onderzoek te plaatsen in het kader van een globale theorie. Leidraad voor de keuze van een theorie was het feit dat het project Integraal Regionaal en de daaruit voortvloeiende onderzoeken waren gericht op het in interorganisationeel verband oplossen van een zorgprobleem. Dit interorganisationele verband is te beschouwen als een netwerk. Het ligt daarom voor de hand om een integratieve theorie te kiezen die het interorganisationele netwerk zelf als onderwerp van studie neemt. Organisaties die participeren in interorganisationele netwerken zijn voor hun functioneren in veel opzichten afhankelijk van acties van andere participanten in het netwerk. Deze gewenste acties komen door omstandigheden van uiteenlopende aard in de praktijk niet altijd tot stand (Hasenfeld 1983). Een theorie die hiervoor verklaringen biedt kan gevonden worden in het werk van. Benson (1975).

Benson analyseert netwerken van organisaties in termen van twee deels gerelateerde, en deels autonome concepten. Enerzijds wordt de analyse gericht op de direct waarneembare acties van organisaties in de praktijk van alledag. Een tweede, diepergaande wijze van analyseren is gericht op de omgeving 
van organisaties, die bestaat uit grotere economische, politieke en socialle structuren. Deze omgeving vormt, onder meer via wet- en regelgeving de voorwaardelijke structuur waarbinnen organisaties kunnen functioneren. In de omgeving wedijveren organisaties om de verdeling van middelen uit twee belangrijke bronnen: geld en macht. De uitkomst van deze competitie kan afhankelijk zijn van bepaalde eigenschappen van organisaties, zoals bijvoorbeeld de positie van de organisatie in het interorganisationele netwerk. Zo zal een organisatie met een centrale, strategische positie in het netwerk vaak meer macht verwerven dan een in de periferie opererende organisatie. De uitkomst van de strijd om macht en andere middelen kan worden beïnvloed door de wijze waarop organisaties ingebed zijn in de omgeving. Uiteindelijk is de aard van de ditect waameembare interacties van organisaties volgens Benson altijd in hoge mate afhankelijk van de wijze waarop in de voorwaardelijke structuur de verdeling van macht en andere middelen geregeld is.

Bij het analyseren van de direct waarneembare interacties van organisaties onderscheidt Benson vier dimensies:

- domeinconsensus, dit is de mate waarin tussen de participanten in het netwerk overeenstemming bestaat over elkaars taken en werkterrein.

- ideologische consensus; dit is de mate van overeenstemming met betrekking tot visie van waaruit het werk wordt verricht,

- positieve evaluatie, dit is de mate warin men positief oordeelt over elkaars werk,

- werk-coördinatie, dit is de mate van afstemming van wederzijdse activiteiten.

In plaats van de term (positieve) evaluatie geven wij er de voorkeur aan om het begrip beeldvorming te gebruiken. Evaluatie heeft betrekking op situaties warin men op basis van daadwerkelijke samenwerking in staat is om de waarde van elkaars werk rationeel te beoordelen. Beeldvorming verwijst veeleer naar beelden die men heeft van elkaars functioneren in situaties waarin samenwerking nog niet echt van de grond is gekomen.

Tussen de vier dimensies bestaat een onderlinge samenhang. Benson analyseert de acties van organisaties namelijk in termen van evenwicht: een interorganisationeel netwerk verkeert in evenwicht wanneer op de vier dimensies min of meer identiek gescoord wordt. Een netwerk is uit zijn evenwicht wanmeer op de dimensies afwijkend wordt gescoord. In een interorganisationele constellatie kan de stand van zaken met betrekking tot elk van de 4 aspecten op elk willekeurig moment worden gekarakteriseerd op een continuüm dat verloopt van hoog tot laag. De waarderingen op dit continuüm ten 
aanzien van de vier aspecten zullen volgens Benson in de praktijk binnen één netwerk meestal niet ver uiteenlopen. Bovendien zullen zij binnen een bepaalde bandbreedte met elkaar meebewegen omdat veranderingen op én van de vier dimensies in de regel zullen leiden tot veranderingen op de andere dimensies, en wel in dezelfde richting. Dit leidt tot de vaststelling dat netwerken in balans kunnen zijn op verschillende niveaus van samenwerking. De term evenwicht moet hier niet worden opgevat in de mechanistische betekenis, waarbij een verandering op de ene dimensie vanzelf zal leiden tot aanpassingen op de andere dimensies. Veeleer wordt bedoeld dat er in het netwerk een tendens bestaat tot covariatie op de vier dimensies. In een netwerk waarin tussen de participanten nauwelijks overeenstemming bestaat over domeinen zal ook weinig coördinatie van werkzaamheden voorkomen. Verder zal men elkaars activiteit waarschijnlijk niet positief waarderen. De dynamiek komt tot stand doordat op elk van de vier dimensies veranderingen kunnen optreden die op hun beurt weer als aanjager kunnen fungeren voor veranderingen op de overige dimensies, en daarmee een ontwikkeling in gang zetten naar een nieuwe vorm van evenwicht.

Wanneer de situatie in de Westelijke Mijnstreek wordt geplaatst in de kontekst van de geschetste theorie van Benson ontstaat het volgende beeld. In de regio bestond ten tijde van de start van het project Integraal Regionaal weliswaar enige samenwerking, maar dit was veeleer het geval binnen de eerstelijn dan tussen eerste- en tweedelijn. Eerstelijnsdisciplines hadden zich net verenigd in de Kerngroep Eerstelijn, en wilden vanuit dit platform de samenwerking en coördinatie binnen de eerstelijn verbeteren. Samenwerking tussen eerste- en tweedelijn op het gebied van thuiszorg was een geheel nieuw fenomeen. Over een gemeenschappelijke visie op zorg die de grenzen van de echelons overschreed was nog niet nagedacht. Deze situatie is schematisch getypeerd in figuur 1 .

In deze schematische weergave is er sprake van een interorganisationeel evenwicht, maar op een betrekkelijk laag niveau van samenwerking. In de geschetste situatie vroeg het ziekenhuis binnen het Algemeen Samenwerkingsverband de aandacht van de eerstelijn voor het probleem van de verkeerde-bedproblematiek. Ondanks het ontbreken van een visie op dit type problematiek waren participanten het erover eens dat thuiszorg voor patiënten met complexe hulpvragen alleen verbeterd kon worden door verbetering van samenwerking en afstemming omdat de zorgvraag van deze patiëntengroep het reguliere aanbod van de eerstelijn te boven ging. 


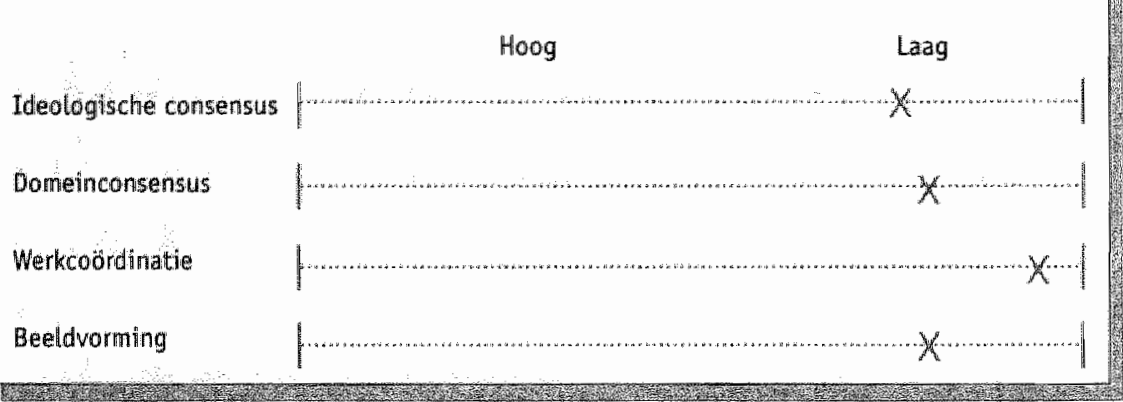

In het project Integraal Regionaal zijn dan ook met name op de dimensie van de werkcoördinatie -dus op zorgverlenersniveau-pogingen ondernomen om de afstemming te verbeteren tussen de twee tot dan toe vrijwel gescheiden werelden van eerste- en tweedelijn. Nieuwe coördinatiemechanismen van diverse aard werden beproefd: een algemeen meld- en coördinatiepunt, speciale transmurale overdrachtformulieren, gemeenschappelijke intake en indicatiestelling, protocolontwikkeling, multidisciplinair overleg, en transmuraal case management.

Bij het ingestelde algemene meld- en coördinatiepunt konden patiênten worden aangemeld voor thuiszorg. Dit gebeurde met behulp van door zorgverleners uit ziekenhuis en eerstelijn gezamenlijk ontwikkelde overdrachtformulieren. Na aanmelding nam het coördinatiepunt contact op met de instellingen, en werden aangemelde patiënten besproken in een speciaal daartoe ingestelde geintegreerde indicatiecommissie, bestaande uit zorgverleners uit eerste- en tweedelijnsinstellingen. Hier werd de beslissing genomen of patiënten daadwerkelijk in thuiszorg werden genomen, en werden individuele zorgplannen opgesteld. Op casusnivo werd vervolgens gecoördineerd via het in elke casus aanstellen van een zorgcoördinator. A werkende werden tenslotte de werkafspraken en taakverdeling tussen de hulpverleners van verschillende disciplines vastgelegd, hetgeen kan worden geduid als een poging tot protocolontwikkeling.

Zoals vermeld in hoofdstuk 1 werd aan het eind van de experimentele projectfase de daadwerkelijke overdracht van patiënten gestopt omdat men het niet eens kon worden over de financiële gevolgen van de overgang van patiënten naar de thuiszorg. Dit betekende echter nog niet het eind van de pogingen tot verbetering van de coördinatie. De positieve resultaten die 
behaald waren in de experimentele fase hadden ervoor gezorgd dat op directieniveau werd besloten om een multidisciplinair panel van zorgverleners uit eerste- en tweedelijn nog een jaar lang alle in het ziekenhuis voorkomende verkeerde-bedpatiënten met CVA te laten bespreken. Hierbij heeft de nadruk gelegen op de vraag of, en zo ja onder welke voorwaarden, multidisciplinaire zorg onder gezamenlijke verantwoordelijkheid thuis of in een verzorgingshuis mogelijk was. Alle genoemde pogingen om de werkcoördinatie op te voeren zijn zeer tijdrovende en arbeidsintensieve processen geweest, waarbij zich veel problemen hebben voorgedaan. Zowel uit de evaluatierapportage die in opdracht van WVC is verricht (van Raak et al 1992) als uit de eindrapportage door het ASV-Westelijke Mijnstreek aan het Ministerie van WVC (1993) blijkt dat verschillen in culturen hierbij van grote betekenis zijn geweest. Niet-geïntegreerde netwerken van au tonome participanten worden vaak gekenmerkt door het ontbreken van een gemeenschappelijke cultuur, waardoor de samenwerking belemmerd wordt. Een gemeenschappelijke cultuur kan alleen ontstaan wanneer men veel en intensief met elkaar omgaat. De in het project ondernomen coördinatiepogingen hebben deze functie zeker gehad, en hebben dan ook in belangrijke mate bijgedragen aan verhoging van inzicht in elkaars werk, aan begrip voor elkaars mogelijkheden en problemen, en daarmee aan een positieve waardering van elkaars werkzaamheden, hetgeen kan worden geduid als een stap in de richting van een gemeenschappelijke werkcultuur. Tevens werden doublures, hiaten en knelpunten in de zorgverlening duidelijk, alsmede de haalbaarheid van de voorgestelde oplossingen (Hermans 1992, van Raak et al 1992, 1993).

Het model van Benson suggereert dat de veranderingen op zorgverlenersniveau op de dimensies van de werkcoördinatie en de beeldvorming kunnen leiden tot veranderingen op de overige dimensies. Is dit nu ook daadwerkelijk gebeurd?

Zowel aan het begin als aan het eind van het project werd het project door de participanten op beleidsnivo als zeer belangrijk voor de eigen doelen bestempeld. Bovendien werden de voordelen groter dari de nadelen geacht (van Raak et al 1993). Toch moet worden geconstateerd dat de verbeterde werkcoördinatie en beeldvorming niet direct tot hechte integratie hebben geleid. Overeenstemming op de ideologische dimensie was ook aan het eind van het project niet bereikt (er bestond geen gezamenlijk gedragen visie op zorg), alhoewel directies van aan het project deelnemende instellingen op dit punt zeker dichter bij elkaar gekomen zijn. Daarnaast was ook gebrek aan consensus op de domeindimensie debet aan het uitblijven van integratie. De 
eerstelijn bleef er bevreesd voor dat het ziekenhuis via het project een nieuw domein wilde betreden: zorg buiten de muren van de eigen instelling. Dit was het domein waarop de eerstelijnsinstellingen primair zelf zorg wilden blijven verlenen. De wrees bestond dat het doorvoeren van de beproefde innovatieve ontwikkelingen ingrijpende gevolgen zou kunnen hebben voor de positie van instellingen in het veld, en voor de wijze waarop zij tot dan toe hun werk hadden georganiseerd en uitgevoerd (van Raak et al 1992).

Tenslotte zijn ook omgevingsfactoren zeker van invloed geweest op het verloop van de ontwikkelingen. De ontwikkeling naar thuiszorg voor patiënten met complexe zorgvragen zou waarschijnlijk voorspoediger zijn verlopen als de stelselherziening die ten tijde van het project in discussie was, in een snel tempo zijn beslag had gekregen. Algemeen wordt immers erkend dat schotten in de financieringsstromen daadwerkelijke zorgvernieuwing in de weg staan: zorgsubstitutie wordt belemmerd doordat het geld de verschuiving van zorg niet kan volgen. Uit de rapportages van van Raak et al (1992, 1993) blijkt dat projectparticipanten in dit opzicht grote verwachtingen hebben gehad van de beoogde stelselwijziging. Doordat deze zich aanmerkelijk langzamer voltrok dan verwacht werd en uiteindelijk zelfs uit het zicht verdween, raakten projectdeelnemers gedemotiveerd. De instellingen gingen zich afwachtend opstellen en ontwikkelden de neiging om terug te vallen op hun oude posities. Dit leidde ertoe dat de mogelijkheden tot substitutie die in het project waren gebleken, niet op grote schaal in de praktijk werden toegepast.

Gesteld kan worden dat het project hoofdzakelijk gericht is geweest op het opvoeren van de werkcoördinatie. Dit heeft aantoonbare positieve gevolgen gehad op het betrekkingenniveau, en heeft geleid heeft tot nivellering van cultuurverschillen en tot verbetering van de beeldvorming ten opzichte van elkaars werkzaamheden onder hulpverleners van eerste- en tweedelijn. Op instellingsniveau bleef men zich echter, zeker in de eerstelijn, tot het eind van het project terughoudend opstellen vanwege de onzekere gevolgen die zorginnovaties zouden kunnen hebben voor het domein van de eigen instelling. Wanneer het mogelijk zou zijn geweest om substitutie van patiënten vergezeld te laten gaan van substitutie van financiële middelen, zou hiervan een belangrijke stimulans zijn uitgegaan op implementatie van de beproefde vorm van zorgvernieuwing.

De aan het eind van het project ontstane situatie is getypeerd in figuur 2: 


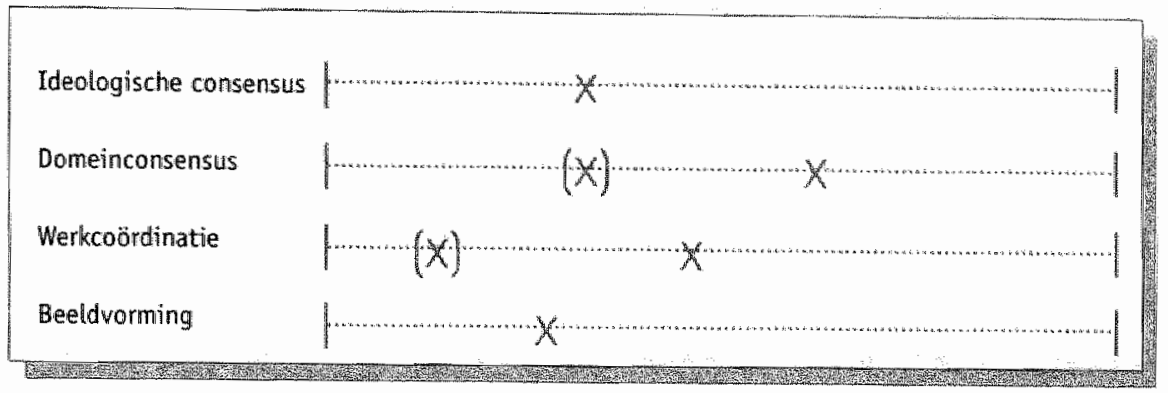

In figuur 2 zijn op de dimensies van domeinconsensus en werkcoördinatie elk 2 merktekens geplaatst. De tussen haakjes geplaatste merktekens duiden op tijdelijke veranderingen die plaats vonden binnen de beschermende structuur van het project. Toen het project beëindigd was en er in de voorwaardelijke structuur geen veranderingen waren opgetreden, viel men vrij snel terug in de richting van de oude posities. De veranderingen die hadden plaatsgevonden op de dimensies van de ideologie en de beeldvorming bleken meer duurzaam van aard te zijn.

\section{AANBEVELINGEN VOOR VERDER ONDERZOEK}

1. Er moet replicatieonderzoek gedaan worden naar de voorspellende waarde van de patiëntkenmerken waarvan een relatie werd gevonden met verkeer" de-bedproblematiek.

2. Er moet praktijkonderzoek gedaan worden om de haalbaarheid van de theoretische substitutiemogelijkheden onder verkeerde-bedpatiěnten met CVA vast te stellen. Om de werkelijk realiseerbare substitutiewinst nader te bepalen zal in dergelijk onderzoek in elk geval aandacht moeten worden besteed aan de mix van het ziektebeloop en de daamee samenhangende (veranderingen in) zorgbehoefte. Verder zal er aandacht moeten zijn voor de invloed van de belasting van de informele zorgers op terugkeer van patiẻnten naar huis.

3. Er moet onderzoek gedaan worden naar de variabelen die een rol spelen in het afwegingsproces van beroepsbeoefenaars van verschillende disciplines met betrekking tot de substitutiemogelijkheden van verkeerde-bedpatiènten. met CVA. 
4. Er moet onderzoek gedaan worden naar de vraag of het de globale (comorbiditeit en ADL-afhankelijkheid) en niet de voor CVA specifieke ziekte- en afhankelijkheidskenmerken (parese en spraakstoornis) zijn die het gebruik van professionele zorg door CVA-patienten in de thuissituatie bepalen.

5. Onderzocht moet worden in hoeverre de professionele en de informele zorg voor thuisverblijvende CVA-patiënten functioneren als gescheiden circuits.

\section{LITERATUUR}

1. Benson, J.K. The interorganizational network as a political economy. Adm Sci Quaterly $1975 ; 20: 229-49$.

2. Hasenfeld, Y. Human service organizations. Englewood Cliffs, New Jersey: Prentice Hall, 1983.

3. Hermans E. Project Integraal Regionaal. Eindrapportage van een project uit het beleidsprogramma Zorgvernieuwing in de Thuiszorg van het Ministerie van WVC. Sittard: Algemeen Samenwerkingsverband Gezonheidszorg en Maatschappelijke Dienstverlening Westelijke Mijnstreek, 1993.

4. Raak A. van, Tijssen I, Jongerius-de Gier G., Ritzen W., Mur-Veeman I. Laten leven om te overleven. Evaluatie "Programma Zorgvernieuwingsprojecten Thuiszorg van WVC", voortgangsrapportage 1991. Maastricht: Rijksuniversiteit Limburg, 1992.

5. Raak A. van, Jongerius-de Gier G., Massop J., Mur-Veeman I. Brug tussen gisteren en morgen; zorgvernieuwing als veranderingsstrategie voor een betere zorg in de toekomst. Evaluatie "Programma Zorgvernieuwingsprojecten Thuiszorg van WVC", eindrapportage. Maastricht: Rijksuniversiteit Limburg, 1993. 


\section{Samenvatting}

In de jaren 1990 tot en met 1992 vond in de regio Westelijke Mijnstreek, nagenoeg samenvallend met het verzorgingsgebled van het Maaslandzlekenhuis Sittard-Geleen het zorgvernieuwingsproject Integraal Regionaal plaats. Het project richtte zich op verkeerde-bedproblematiek, met name onder CVA-patiënten. In een kleinschalig experiment onder een beperkt aantal patiênten, dat onderdeel vormde van het project, was gebleken dat thuiszorg een haalbaar alternatief vormde voor een langer verbliff in het verkeerde bed. Zeven CVA-patiënten in het verkeerde bed werden naar huis geplaatst. Aan het project deelnemende zorgaanbieders hadden zich verplicht om aan deze patienten in de thuissituatie alle benodigde zorg te verlenen. Aan het eind van het experiment werd de conclusie getrokken dat het bieden van thuiszorg aan deze patiënten niet zonder perspectief was, maar dat met het reguliere zorgaanbod de zorgbehoefte van deze patiënten niet gedekt kon worden. Met name gebruikten zij veel meer dan gemiddelde hulp van de gezinsverzorging. Bovendien maakten alle patiënten gedurende hun verblijf thuis gebruik van dagbehandeling in een verpleeghuis gedurende 3 dagen per week.

Naar aanleiding van dit experiment rezen vragen die in de hoofdstukken 2 tot en met 7 van dit proefschrift behandeld worden, en waarvan hieronder samenvattingen volgen.

\section{VERKEERDE-BEDPROBLEMATIEK: OMVANG EN VOORSPELLENDE FACTOREN (HOOFDSTUK 2)}

Ziekenhuizen kampen al jaren met verkeerde-bedproblematiek: bedden die bezet worden door patiënten die geen medisch-specialistische hulp meer nodig hebben waarvoor ziekenhuisverblijf noodzakelijk is, en die toch nog in het ziekenhuis verblijven in afwachting van opname in een residentiële voorziening of van terugplaatsing naar de thuissituatie. De problematiek komt veel voor onder patiënten met CVA. 
Naar aanleiding hiervan hebben wij in het Maaslandziekenhuis SittardGeleen een studie opgezet onder op de neurologische afdelingen opgenomen patiënten. Hiertoe werden alle in 1992 op twee neurologische ziekenhuisafdelingen opgenomen patiënten geregistreerd naar diagnose, leeftijd, geslacht, woonsituatie, en -bij patiënten met CVA- de localisatie van de laesie.

Onderzocht werd:

- wat de omvang was van de verkeerde-bedproblematiek op de neurologische afdelingen van het ziekenhuis, en

- welke patiềntkenmerkenmet de problematiek samenhangen en het ontstaan van de problematiek voorspellen.

\section{Omvang verkeerde-bedproblematiek}

Er werden in het onderzoeksjaar 1992 op de 2 neurologische afdelingen in het Maaslandziekenhuis waar het onderzoek werd verricht in totaal 1088 patiënten opgenomen, waarvan 232 (21\%) met CVA. CVA was hiermee de op een na omvangrijkste opnamecategorie (na lumbale en cervicale aandoeningen). Veertig CVA-patiënten ( $17 \%$ van de opnamecategorie) overleden voordat sprake kon zijn van een verkeerd bed. In totaal kwamen 106 patiënten (10\% van alle opnamen) in het verkeerde bed. Van deze 106 hadden er $91(86 \%)$ de diagnose CVA, waarvan twee RIND (Reversible Ischaemic Neurological Deficit; hierbij zijn de neurologische uitvalsverschijnselen binnen een week verdwenen). Van alle opgenomen patiënten met CVA kwam $40 \%$ in het verkeerde bed; met uitsluiting van de vroegtijdig overledenen was dit zelfs $47 \%$. Patiënten die vanuit het verkeerde bed naar een verpleeghuits werden ontslagen, kenden een verkeerde-bedperiode van gemiddeld 53 dagen. Voor degenen die vanuit het verkeerde bed naar huis werden ontslagen was dit 18 dagen. Van de verpleegdagen op de neurologische afdelingen bestond $20 \%$ uit verkeerde-beddagen van CVApatiènten.

\section{Voorspellende patiëntkenmerken voor verkeerde bedden}

Een CVA-diagnose en een leeftijd van $\geq 70$ jaar waren onder de totale patiëntenpopulatie de twee voorspellers van verkeerde-bedproblematiek. Ook binnen de groep van CVA-patiënten was een leeftijd $\geq 70$ jaar een van de twee voorspellers van verkeerde bedden. Verder hadden vrouwen met een laesie die niet was gelocaliseerd in het stroomgebied van de rechterAarteria Cerebri Media een grotere kans om in een verkeerd bed terecht te komen. 
Geconcludeerd werd dat het gevonden aantal verkeerde-beddagen geëxtrapoleerd naar de Nederlandse situatie neerkomt op een kwart miljoen medisch onnodige verpleegdagen. Zeker bij ongewijzigd beleid, en in samenhang met andere factoren -zoals de dubbele vergrijzing en de voortgaande beddenreducties in algemene ziekenhuizen- kan de verkeerde-bedproblematiek onder CVA-patiënten een bedreiging gaan inhouden voor het functioneren van neurologische afdelingen in algemene ziekenhuizen.

\section{SUBSTITUTIEMOGELIJKHEDEN VOLGENS DE INDIVIDUELE LEDEN VAN EEN MULTIDISCIPLINAIR PANEL (HOOFDSTUK 3)}

In deze studie stond de vraag centraal welk deel van de verkeerdebedpatiënten met CVA in aanmerking zou kunnen komen voor thuiszorg zoals was beproefd in de experimentele fase van het project Integraal Regionaal.

Deze vraag werd benaderd door alle in 1992 in het ziekenhuis voorkomende verkeerde-bedpatiënten met CVA op papier te beschrijven, en over elke patiënt het substitutieoordeel te vragen van een multidisciplinair panel van zorgverleners.

Uitgegaan werd van de in de eerste studie vastgestelde groep van 91 verkeerde-bedpatiënten met CVA. Twee patiënten met Reversible Iscaemic Neurological Deficit en alle patiënten die binnen 10 dagen na de verkeerde-beddatum alsnog uit het ziekenhuis ontslagen werden $(n=20)$ werden geẻxcludeerd. De periode van 10 dagen werd een redelijke termijn geacht waarbinnen een uitbehandelde patiënt ontslagen zou kunnen zijn. Wanneer dit niet het geval was, werd aangenomen dat er een serieus ontslagprobleem bestond. De aldus resterende 69 patiënten ( 44 vrouwen en 25 mannen met een gemiddelde leeftijd 76 jaar) werden op de dag van medische uitbehandeling door het verpleegkundig hoofd van de ziekenhuisafdeling in samenspraak met de behandelend neuroloog op papier beschreven naar: leeftijd, geslacht, woonsituatie voorafgaand aan opname, een inschatting van de kwaliteit van de relaties in het sociale netwerk, algemene typering van het lichamelijk en geestelijk functioneren, en de resterende behoefte aan medische zorg, verpleegkundige zorg en verzorging. 
Het multidisciplinaire panel dat de substitutiemogelijkheden moest beoordelen bestond uit 7 vaste leden: een huisarts, een hoofdwijkverpleegkundige, een hoofd zorg van een instelling voor gezinsverzorging, een hoofd verzorging van een verzorgingshuis, een verpleeghuisarts, en de twee verpleegkundig hoofden van de neurologische ziekenhuisafdelingen.

Onderzocht werd:

- hoe het individuele oordeel van de leden van het panel luidde ten aanzien van de mogelijkheden van elke individuele patiënt om thuis verpleegd en verzorgd te worden als alternatief voor een langer verblijf in het verkeerde bed, $_{\text {. }}$

- in hoeverre de individuele oordelen van de panelleden onderling overeenstemden,

- met welke factoren het oordeel van de individuele panelleden gerelateerd was.

De individuele oordelen van de panelleden over substitutie

De panelleden oordeelden individueel zeer verschillend over de mogelijkheden om aan deze patiënten thuiszorg te bieden. Van de thuiszorgbiedende leden van het panel was de vertegenwoordiger van de gezinsverzorging het meest afhoudend in zijn oordeel. Hij was van mening dat in $77 \%$ van de gevallen thuiszorg onmogelijk was. Voor de huisarts en de hoofdwijkverpleegkundige waren deze scores respectievelijk $54 \%$ en $44 \%$.

De overeenstemming in de oordelen van de panelleden

Ten aanzien van 22 patiènten ( $32 \%$ ) stemden de panelleden unaniem overeen in hun oordeel. Over nog eens $21(30 \%)$ stemden zij bijna unaniem overeen; dat wil zeggen dat hoogstens één panellid een afwijkende mening had. Over $38 \%$ van de patiënten divergeerden de meningen. Onder de intramurale zorgverleners had het oordeel van de verpleeghuisarts de hoogste overeenstemming met dat van extramurale zorgverleners.

Factoren geassocieerd met het oordeel van de panelleden

Het oordeel van alle panelleden hing in hoge mate samen met de zorgbehoefte en de afhankelijkheid van de patiënten. Alleen het oordeel van de huisarts en de gezinszorg was ook gerelateerd met de kwaliteit van de relaties die de patiënten hadden met personen in hun sociale netwerken. 
Geconcludeerd werd dat het onderscheid tussen patiënten die zeker wél, en patiënten die zeker niet naar huis kunnen, voor zorgverleners niet moeilijk te maken is. Voor de overigen -circa een derde deel van de populatie- is dit onderscheid moeilijker te maken en lopen de meningen tussen extra- en intramurale professionals uiteen. Hiervoor wordt multidisciplinair overleg aanbevolen.

\section{SUBSTITUTIEMOGELIJKHEDEN: EEN PANELOORDEEL OP BASIS VAN CONSENSUS (HOOFDSTLIK 4)}

Nadat de leden van het panel hun individuele oordeel over substitutie naar de thuiszorg hadden gegeven, werd in een volgende studie aan de vier niet-klinische zorgverleners uit het panel (de huisarts, de hoofdwijkverpleegkundige, het hoofd zorg van de instelling voor gezinsverzorging en het hoofd verzorging van het verzorgingshuis) gevraagd om op basis van onderling overleg te komen tot een consensus-oordeel over de substitutiemogelijkheden. Behalve substitutie naar huis werd hierbij ook substitutie naar een verzorgingshuis in ogenschouwgenomen. De hieraan ten grondslag liggende overweging was dat, in gevallen waarin substitutie naar huis niet mogelijk werd geacht -bijvoorbeeld omdat er thuis onvoldoende mantelzorg aanwezig was- plaatsing van de betreffende patiënt in een verzorgingshuis wellicht wel tot de mogelijkheden behoorde.

Onderzocht werd:

- hoe groot het aantal patiënten was dat volgens het panel naar huis of naar een verzorgingshuis ontslagen zou kunnen worden, en hoe dit theoretisch mogelijke ontslagpatroon zich verhoudt tot het werkelijke ontslagpatroon,

- onder welke voorwaarden de theoretisch aanwezige substitutiemogelijkheden gerealiseerd zouden kunnen worden,

- welke de kenmerken zijn die het onderscheid bepalen tussen patiënten die door het panel wel en niet substitueerbaar worden geacht.

Het consensus-oordeel van het panel en de relatie met het werkelijke ontslagpatroon uit het ziekenhuis

Het consensus-oordeel van het panel was dat voor 28 van de 69 patiënten substitutie naar de thuiszorg of naar een verzorgingshuis mogelijk was. In werkelijkheid werden slechts 8 patiënten naar huis ontslagen, en geen naar 
een verzorgingshuis. Een theoretisch mogelijke substitutie van $38 \%$ blijft onbenut.

\section{Voorwaarden om substitutie te realiseren}

Om substitutie nat een verzorgingshuis daadwerkelijk te realiseren, was volgens het panel slechts in een enkel geval meer dan reguliere inzet van verzorgend personeel noodzakelijk. Om verplaatsing van zorg naar huis mogelijk te maken moest volgens het panel aan meer voorwaarden voldaan worden. Hiervan waren de belangrijkste: dagbehandeling in een verpleeghuis en een meer dan regulier aantal uren verpleging en -vooralverzorging. Meestal waren combinaties van deze voorwaarden noodzakelijk.

\section{Onderscheidende patiëntkenmerken}

De onderzoekspopulatie viel door de combinatie van het werkelijke, en het door het panel mogelijk geachte ontslagpatroon uiteen in 3 groepen:

b een groep mét substitutiemogelijkheden,

c een groep zonder substitutiemogelijkheden.

Deze groepen zijn met elkaar vergeleken naar zorgbehoefte en athankelijkheid. Groep a) nam hierbij steeds de gunstigste, en groep c) de ongunstigste positie in. Groep b) nam steeds de tussenpositie in.

Geconcludeerd werd dat volgens het consensus-oordeel van een multidisciplinair panel een derde deel van de verkeerde-bedpatiènten met CVA die in de huidige situatie niet naar huis of naar een verzorgingshuis worden ontslagen, in theorie naar één van deze bestemmingen ontslagen kan worden. Substitutie naar een verzorgingshuis stuitte volgens het panel op minder belemmeringen dan substitutie naar huis.

\section{MULTIDISCIPLINAIRE REPRODUKTIE VAN EEN PANELOORDEEL (HOOFDSTUK 5)}

Het in de twee vorige hoofdstukken beschreven panelonderzoek had zich afgespeeld in het verzorgingsgebied van het Maaslandziekenhuis, en het panel bestond uit willekeurige regionale zorgverleners. Daarom stelden wij ons de vraag naar de betrouwbaarheid van het paneloordeel.

Het globale doel van deze studie was om te onderzoeken in hoeverre het consensus-oordeel van het panel uit het vorige hoofdstuk (panel I) door 
andere zorgverleners te reproduceren was. Hiertoe werd een panel van 38 zorgverleners (panel II) samengesteld: 4 hoofdwijkverpleegkundigen, 5 leidinggevenden gezinsverzorging, 5 huisartsen, 5 afdelingshoofden uit verzorgingshuizen, 5 afdelingshoofden van neurologische ziekenhuisafdelingen, 5 neurologen, 4 revalidatieartsen, 5 verpleeghuisartsen. Een groot deel van deze zorgverleners was afkomstig van buiten het verzorgingsgebied van het Maaslandziekenhuis.

Onderzocht werd:

- de overeenstemming tussen de oordelen van panel I en panel II als geheel,

- de variatie in overeenstemming tussen de individuele leden van panel II,

- de variatie in overeenstemming tussen de verschillende beroepsgroepen in panel II,

- de variatie in overeenstemming op casusnivo en waar deze aan was toe te schrijven

De overeenstemming tussen panel I en panel II

Als totaal had panel II een redelijke overeenstemming met het oordeel van panel.

De variatie in overeenstemming tussen de individuele leden van panel II Voor 31 van de 38 beoordelaars van panel II was de overeenstemming met het oordeel van panel I significant.

De variatie in overeenstemming tussen de beroepsgroepen in panel II Per beroepsgroep beschouwd bewoog de overeenstemming met panel I zich voor 6 van de 8 beroepsgroepen tussen Kappa-waarden van 0.47 en 0.51 . De neurologische afdelingshoofden en de hoofdwijkverpleegkundigen scoorden als groep lager dan deze range. De verpleeghuisartsen, de afdelings hoofden van de verzorgingshuizen en de leidinggevenden van de gezinsverzorging hadden zowel de hoogste intra-disciplinaire overeenstremming als een hoge overeenstemming met het oordeel van panel $\mathbb{I}$. De neurologen, revalidatieartsen en neurologische ziekenhuisafdelingshoofden hadden zowel een lage onderlinge overeenstemming als een lage overeenstemming met het oordeel van panel I. Huisartsen en hoofdwijkverpleegkundigen namen de tussenposities in. 


\section{De overeenstemming op casusnivo}

Er bleek op casusnivo aanzienlijk verschil te bestaan in de overeenstemming met het oordeel van panel I. Om te onderzoeken waaraan dit verschill was toe te schrijven vroegen wij aan vijf onafhankelijke zorgdeskundigen om elke casus te beoordelen op de aanwezigheid van informatie over 4 aspecten: ziekte-ernst, psychische toestand, zorgafhankelijkheid en mantelzorgsituatie. Het bleek dat de overeenstemming met het oordeel van panel I beter was naarmate de casus meer informatie bevatte over mantelzorgaspecten.

Geconcludeerd werd dat er een redelijke overall overeenstemming bestond met het oordeel van panel I, en dat dit een goede basis biedt om tat overeenstemming in oordeelsvorming te komen over de meest adequate vervolgzorg ten behoeve van deze patiëntengroep. Op basis van de resultaten van deze studlie kwalificeren in elk geval vertegenwoordigers van verzorgingshuizen, gezinsverzorging en verpleeghuisgeneeskunde zich voor deelname aan multidisciplinair overleg om het vervolgzorgtraject van verkeerde-bedpatiënten met CVA te beoordelen.

\section{LANGE TERMIJN UITKOMSTEN EN SUBSTITUTIEWINST (HOOFDSTUK 6)}

In deze studie werden de uitkomsten op lange termijn onder de verkeerdebedpatiënten met CVA onderzocht. De achterliggende gedachte was dat het paneloordeel aanzienlijk aan waarde zou winnen indien het niet alleen bruikbaar zou blijken te zijn om ad hoc te differentiëren naar uitstroomcategorieën uit het ziekenhuis, maar indien deze uitstroomcategorieën ook gerelateerd zouden blijken te zijn met uitkomsten op lange termijn. Als lange termijn uitkomst werd gekozen voor het al dan niet in leven zijn en de verblijfplaats na drie jaar De studie werd verder opgezet om met behulp van de lange termijn uitkomsten een indicatie te verkrijgen van de omvang van de haalbare substitutie. Het hiervoor gehanteerde rekenmodel werd gebaseerd op het consensus-oordeel van het panel over substitutie. Indien een patiënt met een positief paneloordeel na drie jaar inderdaad thuis verbleef, werd de haalbaarheid van substitutie waarschijnlijker geacht. Indien de betreffende patiënt na 3 jaar niet thuis verbleef werd substitutie minder waarschijnlijk geacht. 
Onderzocht werd:

- hoeveel van de door het panel gescreende patiënten na 3 jaar nog in leven waren en welke gang zij gemaakt hadden door het zorgsysteem,

- of er een verband bestond tussen het paneloordeel over substitutie en het al dan niet in leven zijn na 3 jaar,

- in hoeverre de lange termijn uitkomsten indicaties opleveren van de omvang van de mogelijke substitutie.

\section{Driejaars overleving en de routes door het zorgsysteem}

Van de onderzoeksgroep van 65 patiënten waren er na 3 jaar nog $26(40 \%)$ in leven. Elf ( $17 \%$ van de totale populatie, $42 \%$ van de overlevenden) woonden thuis of in een verzorgingshuis; de overige 15 woonden in een verpleeghuis. Er bestond aanzienlijke variatie in de routes die de patiënten aflegden door het zorgsysteem. Het patroon dat het meest voorkwam was dat patiënten vanuit het ziekenhuis naar een verpleeghuis ontslagen werden en aldaar overleden.

\section{De relatie tussen driejaars overleving en het paneloordeel}

Driejaars overleving was significant geassocieerd met een positief paneloordeel over substitutie. Van de 28 patiënten met een positief paneloordeel waren er $16(57 \%)$ nog in leven tegenover 10 van de $37(32 \%)$ met een ongunstig paneloordeel.

\section{Mogelijke substitutiewinst}

Met het gehanteerde rekenmodel werd, geëxtrapoleerd voor de Nederlandse situatie, een harde substitutiewinst van 4.810 en een zachte substitutiewinst van 22.644 patiëntmaanden in revallidatiecentra en -vooral-verpleeghuizen berekend.

Geconcludeerd werd dat het paneloordeel door de relatie met driejaarsoverleving aan betekenis gewonnen heeft, en dat de beoordeling van de uitstroommogelijkheden uit het ziekenhuis waarschijnlijk overlapt met de kansen op overleving en terugkeer naar de eigen woonomgeving. De berekende theoretische substitutiewinst is substantieel genoeg om nader onderzoek te entameren naar de praktische haalbaarheid ervan. 


\section{ZORGGEBRUIK THUIS GEDURENDE 3 JAAR NA ZIEKENHUISONTSLAG (HOOFDSTUK 7)}

In deze laatste studie stond de vraag centraal hoe het de patiënten uit de onderzoekscohort was vergaan die zonder verkeerde-bedperiode vanuit het ziekenhuis naar huis waren ontslagen $(n=82)$. Het beloop onder deze patiënten in de drie jaar na ziekenhuisontslag staat in tabel 1.

TABEL 1. BELOOP GEDURENDE 3 JAAR NA ZIEKENHUISVERBLIJF ONDER PATIËNTEN DIE ZONDER VERKEERDE-BEDPERIODE NAAR HUIS ONTSLAGEN WERDEN (N=82).

$\begin{array}{lr}\text { Opgenomen in verzorgingshuis } & 6 \\ \text { Opglenomen in verpleeghuts } & 1 \\ \text { Overleden } & 16 \\ \text { Nog thuis verblijvend } & 49 \\ \text { Niet te traceren } & 10 \\ & \\ \text { TOTAAL } & 82\end{array}$

De 49 patiënten die 3 jaar na ontslag uit het ziekenhuis nog in leven waren en thuis woonden werden schriftelijk uitgenodigd deel te nemen aan een vraaggesprek. In 16 gevallen (33\%) werd geen reactie ontvangen of werd medewerking geweigerd, zodat de onderzoeksgroep 33 patiënten omvatte (17 mannen, 16 vrouwen; gemiddelde leeftijd 63 jaar). Van hen was $58 \%$ uit het zilekenhuis ontslagen met een niet geheel herstelde parese, en $40 \%$ met een niet geheel herstelde spraakstoornis.

Onderzocht werd:

- welke zorg deze patiënten ontvingen in de 3 jaar volgend op ziekenhuisverblijf,

- welke beperkingen deze patiênten in de thuissituatie ondervonden,

- in welke mate de de centrale familiezorgers emotionele problemen hadden met de beperkingen van de patiënten, en in welke mate zij de familiezorg als zwaar ervoeren,

- welke factoren gerelateerd zijn met het gebruik van professionele zorg en familiezorg en met de last van de familiezorg 
Het zorggebruik in de thuissituatie

Twintig patiènten (61\%) hadden professionele zorg ontvangen in de thuissituatie. Zeventien patiënten (52\%) ontvingen revalidatie (dagbehandeling in een verpleeghuis en/of eerstelijnstherapie). Zes patiẻnten (18\%) ontvingen thuiszorg (wijkverpleging en/of gezinsverzorging) .Drie patiènten kregen zowell revalidatie als thuiszorg. Bij degenen die alleen thuiszorg kregen was de duur van de hulp het kortst (mediaan: 10 weken), bij degenen die zowel thuiszorg als revalidatie kregen was deze het langst (mediaan: 90 weken). Van de centrale familiezorgers zei $88 \%$ familiezorg te geven. De gemiddelde hoeveelheid verleende familiezorg was 37 uur per week.

\section{De onderuonden beperkingen}

Patiënten gaven aan veel problemen te ondervinden. Tweeënvijftig procent rapporteerde comorbiditeit. De gemiddelde score op de Barthel ADL-Index was 17 punten, duidend op lichte handicaps.

Zes problemen vormden een intern consistente schaal (Cronbach's Alpha: 0,71 ): spraakproblemen, emotionele veranderingen, minder uitgaan, minder ontvangst van bezoek, recidief-ervaring, en een gevoel van ondeskundigheid ten aanzien van het ziektebeeld CVA. Deze problemen zijn in de analyse opgenomen als één variabele: de subjectief ervaren ziektelast.

Familiezorgers: emotionele problemen met de beperkingen van de patiënt, en de last van de familiezorg

Elf familiezorgers ( $33 \%$ ) hadden emotionele problemen met de acceptatie van de beperkingen van de patiênt, en eveneens elf gaven aan de familiezorg als zwaar te ervaren.

Factoren gerelateerd met professionele zorg, familiezorg, en de last van de familiezorg

De ontvangst van professionele zorg hing significant samen met objectieve ziekte- en afhankelijkheidswariabelen: een lager dan gemiddelde score op de Barthel ADL-Index en het rapporteren van comorbiditeit. Specifieke ziekte. en afhankelijkheidsfactoren (parese en spraakstoornis) speelden in dit opzicht geen rol. De hoeveelheid familiezorg werd vooral beïnvloed door de subjectief ervaren ziektelast.

De familiezorg werd als zwaar ervaren naarmate men een meer dan gemiddelde hoeveelheid familiezorg verleende, en naarmate men er meer moeite mee had om de beperkingen van de patiënt te accepteren. 
Geconcludeerd werd dat het vooral de globale (comorbiditeit en ADL afhankelijkheid), en niet de specifieke ziektefactoren (parese of een spraakstoornis) zijn die samenhangen met het ontvangen van professionele zorg. Professionele zorg en familiezorg lijken hun eigen determinanten te kennen, en daarmee te functioneren als twee vrijwel gescheiden circuits. 


\section{Summary}

From 1990 to 1992, the Integral Regional care renewal project was carried out in the Westelijke Mijnstreek, an area which almost exactly corresponds with the catchment area of the Maasland hospital Sittard/Geleen. The project focused on the phenomenon of bed-blocking, in particular by stroke patients. A small-scale experiment with a limited number of patients, which was part of the project, proved that home care was a viable alternative for a prolonged, but incorrect, stay in a hospital bed. Seven stroke patients who were actually blocking hospital beds were sent home. The participating care providers had committed themselves to giving these patients all necessary care at home. At the end of the experiment, the conclusion was that providing home care to these patients was not without perspective, but that the 'regular' care offer was insufficient to cover all the care that these patients needed. In particular, they required a much greater amount of care than the average home help agencies provide. In addition, all home patients made use of day-treatment in a nursing home for three days a week.

The experiment raised the questions dealt with in chapters 2 through 7 of the present Ph.D. thesis, a summary of which is given below.

\section{BED-BLOCKING IN NEUROLOGICAL HOSPITAL WARDS: SIZE AND PREDICTIVE FACTORS (CHAPTER 2)}

For years, hospitals have been facing the problem of bed-blocking: hospital beds occupied by patients who no longer need specialist medical treatment. They nevertheless remain in hospital awaiting admission into a residential facility or their return home. This problem is frequently observed among stroke patients.

This situation was the reason for a study among neurological patients of the Maasland hospital Sittard-Geleen. In this study, all patients admitted to two neurological wards in 1992 were registered according to diagnosis, age, 
gender, home situation and - in stroke patients - the localisation of the lesion.

The following aspects were studied:

- The size of bed-blocking in the neurological wards of the hospital, and

- The patient characteristics related to and predicting the bed-blocking problem.

\section{Size of bed-blocking}

During the year 1992, the hospital in which the study was carried out admitted a total of 1,088 patients, of whom $232(21 \%)$ suffered from stroke. This made stroke the second largest admission category (after lumbar and cervical disorders). Forty stroke patients (17\% of the admission population) died before the issue of bed-blocking could arise. A total of 106 patients ( $10 \%$ of all admissions) became bed-blockers. Of these 106 patients, 91 (86\%) were diagnosed with stroke, of whom two had RIND (Reversible Ischemic Neurological Deficit, in which case the neurological deficit symptoms disappear within a week). Of all admitted patients suffering from stroke, $40 \%$ became bed-blockers; if we exclude the premature deaths, the figure even rises to $47 \%$. Patients who were discharged from such a situation to be admitted to a nursing home, on average spent 53 bed-blocking days in the hospital bed. For those who returned home from such a situation, the average period was 18 days. Of all nursing days in the neurological wards, $20 \%$ were bed-blocking days by stroke patients.

\section{Predictive patient characteristics for bed-blocking}

Among the patient population as a whole, a diagnosis of stroke and an age of $\geq$ 70 years were the two predictive values of bed-blocking. Among the group of stroke patients, an age of $\geq 70$ years was also one of the two predictive values of bed-blocking. In addition, fernale patients with a lesion that was not localised in the territory of the right median cerebral artery had a greater chance of becoming a bed-blocker.

The conclusion was that, certainly if policies were not changed and in combination with other factors, such as double ageing and the progressing bed reductions in general hospitals, the issue of bed-blocking among stroke patients could constitute a threat to the operation of neurological wards in general hospitals. 


\section{Substitution options according to the individual members of a multidisciplinary panel (Chapter 3 )}

This study concentrated on the question which section of the bed-blocking stroke patients might be suitable for home care as tested in the small-scale pilot in the Integral Regional project.

The approach to this question included a written description of all bed-blocking stroke patients in 1992, and a theoretical request for substitution, to be answered by a multidisciplinary panel of care providers.

The study included the group of 91 bed-blocking stroke patients from the first study. Two patients suffering from Reversible Ischemic Neurological Deficit and all patients who were discharged within 10 days after the starting date of their bed-blocking period $(n=20)$, were excluded. The period of 10 days was considered a reasonable period of time for the discharge of patients who had completed their treatment. If such were not the case, it was assumed that there was a serious impediment to their discharge. The remaining 69 patients (44 women and 25 men, with an average age of 76 years) were described on paper by the nursing head of the hospital ward in consultation with the relevant neurologist, on the day when their medical treatment was completed. The description included age, gender, living situation prior to hospital admission, an estimate of the quality of their social network relations, general characterisation of their physical and mental functioning, and the remaining need for medical and nursing care and ADL care.

The multidisciplinary panel that was to assess the substitution options, consisted of 7 permanent members, and included a general practitioner, a head community nurse, a head of a home help institution, a head of the nursing staff in a home for the aged, a nursing home physician, and the two nursing heads of the neurological hospital wards.

The following issues were investigated:

- What the individual judgements of the members of the panel were on the possibilities of the patients to be cared for at home, as an alternative for a prolonged stay in a hospital bed.

- To what extent the individual judgements of the panel members corre sponded with each other,

- To which factors the judgements of the individual panel members related.

\section{Individual judgements of panel members on substitution}

The panel members' judgements on the possibilities of providing home care to these patients varied greatly. The representative of the home help agency 
was the most dismissive one. The latter believed that in $77 \%$ of all cases, home care was impossible. For the general practitioner and the head community nurse, the scores were $54 \%$ and $44 \%$, respectively.

\section{Agreement in the judgements of the panel members}

In the case of 22 patients $(32 \%)$, the judgements of the panel members was unanimous. For another $21(30 \%)$, their wotes were almost unanimous, which means that no more than one panel member had a different opinion. With respect to $38 \%$ of the patients, the opinions differed. Among the in-patient care providers, the judgement of the nursing home physician had the highest correspondence with those of the out-patient care providers.

\section{Factors associated with the judgements of the panel members}

The judgement of the panel members was strongly related to the patients* remaining need for care and their dependency. Only the judgements of the general practitioner and the head of the home help institution related to the quality of the relations that the patients had with individuals in their social networks.

The conclusion was that the decision on those patients who certainly can and those who certainly cannot return home, is not difficult to make for care providers. For the other patients - about one third of the population - this distinction is more difficult to make and the opinions differ between professionals providing in-patients' and out-patients' care. For this, multidisciplinary meetings are recommended.

\section{SUBSTITUTION OPTIONS: A PANEL JUDGEMENT BASED ON CONSENSUS (CHAPTER 4)}

After the members of the panel had given their individual judgements on substitution by home care, a subsequent study consisted of asking the four nonclinical care providers in the panel the general practitioner, the head community nurse, the head of the home help agency, and the head of the nursing staff in the home for the aged) to meet for discussion and to arrive at a consensus judgement regarding the substitution options. Apart from substitution by home care, the option of substitution by care in a home for the aged was also considered. The underlying consideration here was that in those cases in which substitution by home care was not considered a viable option - 
for example because there was insufficient informal care available at home admission of the patient concerned to home for the aged might be an option.

The following issues were investigated:

- How many patients, following the consensus judgement of the panel, could theoretically be discharged from the hospital to their homes home or to a home for the aged, and how this theoretical discharge pattern relates to the actual discharge pattern,

- Under which circumstances the theoretical substitution options could be achieved in practice,

- Which characteristics determine the difference between patients whom the panel regards as substitutionable and non substitutionable.

\section{Consensus judgement of the panel and its relation to the hospital discharge pattern}

The consensus judgement of the panel was that for 28 of the 69 patients, substitution by home care or a home for the aged was possible. In reality, only 8 patients were discharged to return home, while none went to a home for the aged.

\section{Preconditions for substitution}

In order to actually achieve substitution by a home for the aged, the panel believed that this would only occasionally require more than the regular efforts of the nursing staff. To enable patients to retum home meant that more conditions had to be met, according to the panel. The main ones were outpatient treatment in a nursing home and an above-standard number of nursing hours and - in particular - ADL care hours. In most cases, combinations of these conditions were required.

\section{Distinguishing patient characteristics}

As a result of the combination of the actual discharge pattern and the possible discharge pattern, the study population was divided into 3 groups:

a a group that actually was discharged home,

b a group with substitution options,

c a group without substitution options.

These groups were compared as to their dependency and need for care. Group a) in al cases had the most favourable position, while group c) always had the least favourable one. Group b) always had the middle position. 
The conclusion was that according to the consensus judgement of a multidisciplinary panel, one third of the bed-blocking stroke patients could in theory be discharged home or to a home for the aged. Substitution by a home for the aged met with fewer objections from the panel than substitution by home care.

\section{MULTIDISCIPLINARY REPRODUCTION OF THE PANEL JUDGEMENT (CHAPTER 5)}

The panel study described in the previous two chapters took place within the catchment area of the Maasland hospital, and the panel consisted of randomly chosen regional care providers. We therefore asked ourselves the question how reliable the judgement of the panel was.

The overall aim of this study was to investigate to what extent the consensus judgement of the panel in the previous chapter (Panel I) could be reproduced by other care providers. For this purpose, a panel consisting of 38 care providers (Panel II) was set up: 4 head community nurses, 5 home help supervisors, 5 general practitioners, 5 department heads from homes for the aged, 5 ward heads of neurological hospital wards, 5 neurologists, 4 rehabilitation specialists, and 5 nursing home physicians. Many of these care providers were from outside the catchment area of the Maasland hospital.

The following issues were investigated:

- The degree of correspondence between the judgements of Panels I and II as a whole,

- The variance of agreement between the individual members of Panel II,

- The variance of agreement between the different disciplines in Panel II,

- The variance in agreement on individual cases, and to what this could be attributed.

Agreement between Panel I and Panel II

On the whole, Panel II agreed quite well with the judgements of Panel I (Kappa 0.48).

Variance of agreement between individual members of Panel $I I$

For 7 of the 38 assessors in Panel II, the agreement with the judgement of Panel I was not significant. 


\section{Variance of agreement between occupational groups in Panel II}

Considering each occupational group individually, the agreement with Panel I varied between the Kappa values 0.47 and 0.51 , for 6 out of the 8 occupational groups. As a group, the heads of neurological wards and the head community nurses scored below this range. The nursing home physicians, the department heads of the homes for the aged and the home help supervisors had both the highest intradisciplinary agreement and a high degree of agreement with the judgements of Panel I. The neurologists, rehabilitation specialists and the heads of neurological wards both had a low degree of internal agreement and a low degree of agreement with the judgements of Panel I. General practitioners and head district nurses took up intermediate positions.

\section{Agreement at individual case level}

At the level of individual cases, there was a considerable difference in agreement with the judgements of Panel I. It appeared that the agreement with the judgements of Panel I was greater if there was more information on aspects of informal care.

The conclusion was that there was a reasonable degree of overall agreement with the judgements of Panel $I_{y}$ and that this constitutes a good basis for arriving at decisions regarding the most appropriate follow-up care for this group of patients. On the basis of the results of this study, at least the representatives of homes for the aged, home help, and nursing home medicine qualified for participation in multidisciplinary consultation on the assessment on the follow-up route of bed-blocking stroke patients.

\section{LONG-TERM RESULTS AND SUBSTITUTION BENEFITS (CHAPTER 6)}

This study looked at the long-term results among bed-blocking stroke patients. The underlying idea was that the value of the panel judgement would greatly increase if it could not only be used to differentiate between hospital discharge categories on an ad hoc basis, but would also prove to be related to long-term results. Another aim of the study was to use the long-term results to obtain an idea of the size of the substitution that could be achieved. The calculation model used was based upon the panel's consensus judgement on substitution. If a patient who received a positive panel judgement was indeed at home after three years, the viability of substitution was 
considered more likely. If the patient concerned was not staying at home after 3 years, substitution was considered less likely. As long-term results we selected the patient's being alive or not, and where he/she was staying after 3 years.

The following issues were investigated:

- How many of the patients screened by the panel were still alive after 3 years, and what route they had taken through the care system,

- Whether there was a relationship between the panel judgement about substitution and the patient's being alive or not alive after 3 years,

- To what extent the long-term results provided indicators regarding the extent of possible substitution.

Three-year survival rates and the routes through the care system Of the study group of 65 patients, $26(40 \%)$ were still alive after 3 years. Eleven ( $17 \%$ of the total population, $42 \%$ of the survivors) lived at home or in a home for the aged; the other 15 lived in a nursing home. There was considerable variance as to the routes that the patients had taken through the care system. The most common pattern consisted of patients leaving the hospital to enter a nursing home and stay there until their death.

\section{Relationship between three-year survival rate and panel judgement}

The three-year survival rate was significantly associated with a positive judgement on substitution by the panel. Of the 28 patients who had a positive panel judgement, $16(57 \%)$ were still alive, against 10 out of the $37(32 \%)$ with an unfavourable panel judgement.

\section{Possible substitution benefit}

Using our calculation model and extrapolating for the situation in the Netherlands as a whole, we calculated a hard substitution benefit of 4.810 and a soft substitution benefit of 22.644 patient months in rehabilitation centres and - in particular - nursing homes.

The conclusion was that the value of the panel judgement increased as a result of the relationship with the three-year survival rate, and that the assessment of discharge options from the hospital is likely to overlap with the chances of survival and return home. The calculated theoretical substitution options are substantial enough to justify further research as to their practical viability. 


\section{HOME CARE DURING 3 YEARS AFTER DISCHARGE FROM HOSPITAL (CHAPTER 7)}

The last study focused on the question how patients from the study populaw tion had fared who were discharged home from the hospital without blocking a bed $(n=82)$. The course of these patients during the three years after discharge from hospital is shown in Table 1.

TABLE 1. COURSE OF NON BED-BLOCKING PATIENTS DISCHARGED HOME FROM HOSPITAL ( $(\mathrm{N}=82$ ), DURING 3 YEARS AFTER HOSPITALISATION

\begin{tabular}{lc}
\hline Admitted to rest home & 6 \\
Admitted to nursing home & 1 \\
Deceased & 16 \\
Still at hame & 49 \\
Untraceable & 10 \\
& 82 \\
\hline
\end{tabular}

The 49 patients who were still alive and living at home 3 years after discharge from hospital, received a letter inviting them to take part in an interview. In 16 cases (33\%), there was no reply or co-operation was refused, creating a study population of 33 patients ( 17 men, 16 women; average age: 63 years). Of these patients, $58 \%$ was discharged from the hospital with a paresis that was not or only partially cured, while $40 \%$ was discharged with a speech defect that was not or only partially cured.

The following issues were investigated:

- What care did these patients receive during the 3 years following their hospitalisation,

- Which disabilities did these patients experience at home,

- To what extent the family care providers had emotional problems as a result of the disabilities experienced by the patients, and to what degree they regarded the family care as difficult,

- Which factors were related to the use of professional care and family care, and to the burden of family care 


\section{Use of care at home}

Twenty patients $(61 \%)$ had received professional care at home. Seventeen patients $(52 \%)$ received rehabilitation (day treatment in a nursing home and/or ambulant therapy). Six patients ( $18 \%)$ received home care (district nursing and/or home help). Three patients received both rehabilitation and home care. For those who only received home care, the duration of the care period was shortest (median: 10 weeks), while it was the longest for those who received both home care and rehabilitation (median: 90 weeks). Of the core family care providers, $88 \%$ said that they provided family care. The average number of hours of family care provided was 37 hours per week.

\section{Disabilities}

Patients indicated that they experienced many problems. Fifty-two per cent reported comorbidity. The average score on the Barthel ADL Index was 17 points, indicating mild handicaps.

Six problems constituted an internally consistent scale (Cronbach's Alpha: 071): speech impediments, emotional changes, going out less frequenty, receiving fewer visitors, relapses, and a feeling of incompetence with regard to the stroke syndrome. These problems were included in the analysis as a single variable: the burden of illness.

Family care providers: emotional problems relating to the disabilities of the patients and the burden of family care

Eleven family care providers (33\%) experienced emotional problems with regard to the acceptance of the patient's disabilities, and also eleven indicated that they regarded providing family care as difficult.

\section{Factors relating to professional care, family care and the burden of family} care

Receiving professional care was significantly related to objective illness and dependency variables: a lower than average score in the Barthel ADL Index and reporting comorbidity. Specific illness and dependency factors (paresis and speech defect) did not play a role in this respect. The amount of family care was affected in particular by the burden of illness.

Family care was regarded as difficult when an above-average amount of family care was provided, and when the individual concerned had greater difficulty accepting the patient's disabilities. 
The conclusion was that it is in particular the general illness factors (comorbidity and ADL dependency), rather than the specific illness factors (paresis or speech defect) that are related to receiving professional care. Professional care and family care appear to have their own determinants, and thus seem to function as two almost separated circuits. 


\section{Dankwoord}

Het schrijven van een proefschrift is een bezigheid die ambivalente gevoelens oproept. Aan de ene kant is het een fascinerende ontdekkingsreis, anderzijds is het een lange, zware en in wezen toch eenzame strijd. Gevoelens van de laatste soort worden vooral ervaren wanneer het werk, zoals in mijn geval, moet worden verricht in avonduren, weekends en vakanties. Het zal duidelijk zijn dat zo'n karwei niet zonder de steun van anderen te volbrengen is. Die anderen wil ik bedanken.

In de eerste plaats gaat mijn dank uit naar Dr. H.W.M. Anten, neuroloog in het Maaslandziekenhuis Sittard-Geleen. Bert, zonder jouw belangeloze en op afroep beschikbare hulp was dit proefschrift er nooit gekomen. Ik ben je veel dank verschuldigd voor de vele uren die je met mij besteed hebt aan het verzamelen en verifiëren van het materiaal, voor je bijdragen als co-auteur aan vier artikelen, voor je herhaalde proof-readings van de manuscripten, en voor je vele deskundige adviezen!

Uiteraard bedank ik mijn promotor Prof. Dr. H. Philipsen. Hans, je gaf me alle ruimte, maar ik wist dat je er altijd was wanneer ik je nodig had. Ik dank je oprecht voor je steeds inspirerende en geduldige begeleiding. Je had altijd weer een verhelderende kijk, en je deskundige hulp bij de allerlaatste loodjes is voor mij van grote waarde geweest.

Bij mijn co-promotor Dr. J.P.M. Diederiks kon ik op elk moment terecht. Jos, in de tientallen vrijdagse bijeenkomsten op jouw kamer heb ik talloze goede ideeën en suggesties opgedaan. Steeds ging ik na zo'n bijeenkomst weer welgemoed huiswaarts met bagage waarmee ik weer een tijd vooruit kon. Ik verzeker je dat je voor mij de constante factor bij uitstek was.

lk bedank de zorgverleners die de patiënten beoordeelden op hun substitutiemogelijkheden, en het bestuur van het voormalige Algemeen Samenwerkingsverband Westelijke Mijnstreek voor het beschikbaar stellen van de data van het project Integraal Regionaal.

Dank ook aan de patiënten en hun familiezorgers die medewerking verleenden aan het onderzoek. Met de inzichten die ontstaan zijn op grond 
van de door hen, en over hen beschikbaargekomen gegevens, kunnen andere CVA-patiênten hopelijk hun voordeel doen.

Van grote waarde was ook iedereen die in de voorbije jaren van tijd tot tijd belangstellend informeerde naar mijn vorderingen. Deze belangstelling was voor mij zeker een stimulans om door te zetten, ook in perioden dat het eens tegenzat.

Tijdens de looptijd van het onderzoek zijn mijn beide ouders overleden. Mijn vader was ongetwijfeld de allerferventste supporter van dit project. Zijn steun en belangstelling vergeet ik nooit meer.

Last but not least bedank ik mijn vrouw en kinderen voor hun geduld en steun. Resi, Lucas en Martijn, ik beloof jullie dat ik een belangrijk deel van de vrijkomende tijd zal investeren in het vervullen van mijn rol van echtgenoot en vader. 


\section{Curriculum Vitae}

Eric Hermans is geboren in Sittard (1946) en studeerde (medische) sociologie aan de Katholieke Universiteit Nijmegen.

Van 1972 tot 1985 was hij docent aan diverse opleidingen in de zorg- en welzijnssector: de in-service opleiding voor verpleegkunde en ziekenverzorging te Geleen, de sociale academie te Sittard en de revalidatie academie te Hoensbroek.

In 1985 werd hij beleidsmedewerker bij het Medisch Regionaal Centrum te Maastricht, het toenmalige samenwerkingsverband van de gezondheidszorg in regio 27 (Zuid-Limburg).

Van 1988 tot 1994 was hij ambtelijk secretaris/coördinator van het Algemeen Samenwerkingsverband Gezondheidszorg en Maatschappelijke Dienstverlening Westelijke Mijnstreek te Sittard. In de periode 1995 - 1997 vervulde hij eenzelfde functie bij het Regionaal Overlegorgaan Zorg voor mensen met een verstandelijke handicap (ROZ) in Breda.

Vanaf begin 1998 is hij verbonden aan het Nederlands Instituut voor Zorg en Welzijn / NIZW in Utrecht, bij het cluster Organisatie van Zorg. 
BIJ LAGE

\title{
Project Integraal Regionaal
}

Zorgvernieuwing in de Westelijke Mijnstreek

\author{
E. Hermans
}

Gepubliceerd in: Medisch Contact 1992; 47: 435-8 


\section{INLEIDING}

In de Westelijke Mijnstreek, met de gemeenten Sittard en Geleen als grotere stedelijke centra, loopt onder verantwoordelijkheid van het Algemeen Samenwerkingsverband Gezondheidszorg en Maatschappelijke Dienstverlening Westelijke Mijnstreek (ASV-WM) sinds 1 januari 1990 het project Integraal Regionaal. Het project wordt gefinancierd door het ministerie van WVC en is een onderdeel van het beleidsprogramma Zorgvernieuwingsprojecten Thuiszorg van dit ministerie. De in dit programma opgenomen projecten hebben een looptijd wan drie jaar. Ook de provincie Limburg draagt financieel bij. Het project past in het beleid van ministerie van WVC met betrekking tot de thuiszorg. Uit vele zorgvernieuwende initiatieven blijkt volgens de staatssecretaris, dat het noodzakelijk is afstemming, samenhang en substitutie door te voeren in de diverse (thuis)zorgonderdelen, waardoor zorg op maat mogelijk moet worden. Om dit te bereiken zijn stimulerende beleidsactiviteiten in gang gezet. Een van die activiteiten is het programma Zorgvernieuwingsprojecten Thuiszorg. Dit programma beoogt een bijdrage te leveren aan verbetering van de thuiszorg als alternatief voor opname in een intramurale setting. De nadruk ligt op het ontwikkelen van zorgcircuits rondom thuiszorg. In de visie van WVC worden dergelijke circuits gekenmerkt door:

- aanspreekbaarheid van deelnemers op een samenhangend thuiszorgaanbod, afgestemd op de behoefte van het cliëntsysteem(zorg op maat);

- het bestaan van duidelijke afspraken over het aandeel van de diverse betrokkenen in de zorg en over de onderlinge samenwerking;

- het werken met een gezamenlijke intake en onderling afgestemde indicatiestellingen;

- het bestaan van afspraken met intramurale voorzieningen over taakverdeling, consultatie, ondersteuning en kwaliteit van zorg;

- de aanwezigheid van een 24-uurs coördinatiepunt.

Er zijn in totaal elf projecten in den lande in het programma opgenomen. De projecten worden geëvalueerd door de onderzoeksgroep van de vakgroep Zorgvernieuwing van de Rijksuniversiteit Limburg. Het evaluatierapport over het jaar 1990 is als boek uitgegeven. Aan het project Integraal Regionaal wordt op basis van een intentieverklaring deelgenomen door de Stichting Ziekenzorg Westelijke Mijnstreek (één ziekenhuis op twee locaties en vier verpleeghuizen), de medische staf van deze stichting en de eerstelijns kerndisciplimes in de regio, verenigd in de Stichting Eerstelijn Westelijke 
Mijnstreek. Ook de regionale zorgverzekeraar Liass en het KLOZ zijn nauw bij het project betrokken.

Het project richt zich op de zogenoemde verkeerde-plaatsproblematiek, een probleem dat een bredere scope heeft dan de bekendere verkeerde-bedproblematiek (voor het verpleeghuis geïndiceerde patiënt bezet ziekenhuisbed), omdat hier de aandacht tevens wordt gericht op:

- medisch uitbehandelde ziekenhuispatiènten zonder verpleeghuisindicatie voor wie - om welke reden dan ook - ontslag uit het ziekenhuis (nog) niet mogelijk is;

- thuis verblijvende patiënten die wachten op klinische opname(wachtlijstproblematiek).

Bij ongewijzigd beleid zal de gezondheidszorg in de regio Westelijke Mijnstreek (en in vele andere regio's), mede gezien de toenemende vergrijzing, in stijgende mate te kampen krijgen met deze problematiek. Reeds thans dreigen hierdoor in het Maaslandziekenhuis Sittard/Geleen afdelingen (neurologie, geriatrie) ontwricht te raken.

De kern van het probleem is, dat veel uitbehandelde oudere patiënten veelal niet goed genoeg zijn om naar huis te kunnen met behulp van ondersteuning door de reguliere eerstelijnszorg, en eigenlijk te goed zijn voor het verpleeghuis. Toch kiezen de ziekenhuisafdelingen in dergelijke gevallen naar eigen zeggen vaak voor de verpleeghuisoptie, omdat de eerstelijnsoptie nóg minder uitzicht biedt. Ook het besluit Intensieve Thuiszorg van de Ziekenfondsraad biedt in dergelijke gevallen niet het gewenste perspectief, omdat de extra hulpbehoefte van deze patiënten meestal structureel en langdurig is. Dit heeft geleid tot de hypothese dat er nogal wat vervuiling zit in de verpleeg* huiswachtlifsten, die zou kunnen worden opgelost door enige toevoeging aan het thuiszorgaanbod. Als oplossing voor dit verkeerde-plaatsprobleem wordt in het project gezocht naar het verbeteren en uitbreiden van de ontslagmogelijkheden van medisch uitbehandelde ziekenhuispatiënten. Uitbreiding van deze mogelijkheden wordt voornamelijk gezocht via het bieden van thuiszorg-met-iets-extra's, dit in de verwachting dat als resultaat de wachtlijsten voor ziekenhuisopname zullen worden ingelopen. Tevens zou, indien bovenstaande veronderstellingen juist zijn, van het project een vermindering van de druk op de verpleeghuizen moeten uitgaan. 


\section{OPZET EN WERKWIJZE}

Het project is onderverdeeld in een drietall deelprojecten, te weten een deelproject neurologie (CVA-patiënten), een deelproject geriatrie en een deelproject orthopedie. In het laatst genoemde deelproject gaat het niet, zoals in de beide andere, om verkeerde-plaatspatiënten; hier gaat het erom de intramurale verpleegduur voor specifieke diagnosegroepen (totale heup operaties) te verkorten. Het laatste deelproject zal verder in dit artikel onbesproken blijven. De keuze voor de specialismen neurologie en geriatrie is tot stand gekomen op grond van het substantiële aandeel dat beide specialismen hebben in de intramurale verkeerde plaatsen. Volgens gegevens van de verplegingsdienst van het Maaslandziekenhuis Sittard/Geleen waren er in de periode april-december 1991 totaal 181 verkeerde-plaatspatiënten in het ziekenhuis (62\% vrouwen; gemiddelde leeftijd 73,5 jaar). Gemiddeld (op basis van vier meetmomenten) verbleven er van hen steeds ongeveer dertig in het ziekenhuis. De voornaamste diagnoses in deze groep waren CVA $(37 \%)$ en dementie/verwardheid(12,7\%). De voornaamste ontslagbelemmering $(72,5 \%$ van de gevallen) betreft ADL-problematiek. De patiënten verbleven vanaf de datum dat ze uitbehandeld waren tot hun ontslag gemiddeld nog 47 dagen in het ziekenhuis. In het project is van meet af aan gekozen voor een sterk doelgerichte aanpak. Binnen elk van de beide deelprojecten neurologie en geriatrie is gestart met een zogenoemde experimentele fase, waarin een beperkt aantal verkeerde-plaatspatiënten uit het ziekenhuis naar huis is overgeplaatst.

Het doel van deze fase was op proefondervindelijke wijze inzicht te verwerven in de aard van de zorg die deze patiënten thuis nodig hebben. Deze patiênten en hun familie waren ervan op de hoogte dat het om een experiment ging. De projectpartners hadden zich vooraf gebonden om aan dit beperkt aantal patiënten alle benodigde zorg daadwerkelijk te verlenen; deel van de afspraak was dat de hulpverlening in de experimentele fase met gesloten beurs zou geschieden.

\section{RESULTATEN}

In de experimentele fase van de deelprojecten neurologie en geriatrie zijn in totaal 11 verkeerde-plaatspatiënten uit het ziekenhuis ontslagen onder voortzetting van zorg aan huis. Omdat het om geringe aantallen gaat, is het trekken van generaliserende conclusies uiteraard onmogelijk. Wel kunnen 
enkele opmerkelijke feiten worden geconstateerd. Deze hebben enerzijds betrekking op de selectie van patiënten voor het project en anderzijds op de resultaten van de thuiszorg in termen van complexiteit en intensiteit.

\subsection{SELECTIE VAN PATIËNTEN}

Zoals reeds gezegd, richt het project zich op in het ziekenhuis verblijvende medisch-specialistisch uitbehandelde patiënten met een ontslagbelemmering. Uiteraard is een belangrijk aantal van deze patiënten onder alle omstandigheden op verpleeghuisopname aangewezen. Voor een aantal anderen zou echter, zo luidde de verwachting, thuiszorg-met-iets-extra's mogelijk moeten zijn.

De afspraak was dat ziekenhuisafdelingen samen met de behandelend specialisten deze potentiële thuiszorgpatiënten zouden selecteren en aanmelden bij het verpleeghuisopnameteam. Dit team zou dan de geschiktheid van de patiënt voor thuiszorg beoordelen. Wanneer dit oordeel positief was, werd het concrete thuiszorgplan rondgemaakt in een commissie van alle betrokken eerste-en tweedelijnshulpverleners. Bij een negatief oordeel verdween de patiënt uit de procedure.

Een opmerkelijke constatering is, dat het selecteren van patiënten die in aanmerking komen voor thuiszorg-met-iets-extra's niet aan intramurale zorgverleners kan worden overgelaten: een structurele inbreng vanuit de eerstelijn is essentieel. Dit bleek in de beginfase van het deelproject neurologie. Ondanks het feit dat intramurale zorgverleners zeer "eager" aan het project waren begonnen, was na een half jaar pas én patiënt in thuiszzorg genomen. De reden was dat van de eerste zes aangemelde patiënten er door het verpleeghuisopnameteam vijf voor thuiszorg werden afgewezen. Hierbij werden steeds (combinaties van)de volgende redenen genoemd:

- te geringe draagkracht van de mantel,

- onvoldoende garanties voor nachtelijke veiligheid,

- ongeschikte huisvestingssituatie.

De vijf afgewezen patiënten zijn uiteindelijk alle vijf blijvend in het verpleeg huis opgenomen. Uiteraard ontstond hierdoor twijfel aan de levensvatbaarheid van het project, tot uiting komend in wederzijdse vragen en irraties. In het ziekenhuis vroeg men zich af welke patiënt dan wél met enige kans op succes voor het project in aanmerking kon komen. Ook in de eerstelijn ontstond wrevel. Men had zich immers - in de sfeer van beschikbare menskracht en middelen- voorbereid op de komst van een aantal zorgbehoevende patiënten, en nu kwam er niemand. Achteraf was dit een ontwikkeling die had 
kunnen worden voorzien. Er werd immers vanuit het ziekenhuis een nieuwe doelgroep aangeboden aan de eerstelijn. Dat zoiets, zeker in de beginfase, overleg tussen eerste- en tweedelijn vergt, is logisch.

Vooraf werd er vanuit gegaan dat het verpleeghuisopnameteam als verbindende schakel tussen ziekenhuis en thuiszorg zou kunnen fungeren. Dat de selectie van patiënten in het begin van de operationele fase vertraging opliep, was het gevolg van ến (of allebei, dat is niet meer te achterhalen) van de volgende factoren:

- ziekenhuiszorgverleners hebben onvoldoende zicht op de gewenste vervolgzorg c.q. de (on)mogelijkheden van thuiszorg, en boden als gevolg daarvan de verkeerde patiënten aan.

- het verpleeghuisopnameteam is té klinisch georiënteerd, waardoor patiënten met thuiszorgmogelijkheden toch in het verpleeghuis zijn opgenomen.

In elk geval is het zo, dat de eerstelijn als zodanig in deze fase van het project geen kans heeft gehad om zich uit te spreken over de thuiszorgmogelijkheden ten behoeve van deze patiënten. Deze ervaringen leidden tot de conclusie, dat de beoogde vernieuwing van zorg niet kon worden bereikt zonder nieuwe overlegstructuren.

Deze conclusie leidde ertoe, dat werd besloten de rol van het verpleeghuisopnameteam in het project te beëindigen en twee projectgroepen in te stellen: één voor neurologie en één voor het later opgestarte deelproject geriatrie. Deze projectgroepen werden verantwoordelijk voor het gehele proces vanaf de patiëntenselectie tot en met het bewaken van het verloop van de thuiszorg. De projectgroepen kenden een waste samenstelling; alle relevante eerste-en tweedelijns hulpverleners waren erin vertegenwoordigd. Na het creëren van dit ontmoetingspunt tussen eerste- en tweedelijn bleek het project wél levensvatbaar te zijn; het afgesproken aantal patiënten kon binnen zeer korte tijd worden geselecteerd en daadwerkelijk in thuiszorg worden genomen. Volgens de betrokken hulpverleners moet dit worden verklaard uit het bestaan van het ontmoetings-, c.q. coördinatiepunt zelf. Hulpverleners uit eerste- en tweedelijn kregen meer oog voor elkaars mogelijkheden en moeilijkheden; ook konden zij gebruik maken van elkaars patiëntengegevens.

\subsection{COMPLEXITEIT EN INTENSITEIT VAN DE THUISZORG}

Een tweede belangrijk punt betreft het resultaat van de verleende thuiszorg. De patiënten waren 8 vrouwen en drie mannen, in leeftijd variërend van 62 tot 85 jaar, met een neurologische of geriatrische diagnose (in 6 gevallen 
CVA). Alle patiênten hadden een verpleeghuisindicatie of zouden deze hebben gekregen als zij niet voor deelname aan het project zouden zijn geselecteerd. Alle patiënten beschikten over een partner die bereid en in staat was enige bijdrage te leveren aan de thuiszorg.

Begin 1992 waren 10 van de 11 patiënten minimaal een half jaar thuis; één patiënt was intussen opgenomen in een verzorgingshuis. Het doel van de thuiszorg bestond in dit geval ook uit overbrugging van de wachttijd voor opname.

In alle elf gevallen bleek, uiteraard met alle denkbare onderlinge verschillen, de thuiszorg voor deze patiënten een haalbare kaart te zijn.

Met betrekking tot de complexiteit en intensiteit van de ingezette zorg kunnen enkele globale lijnen worden getrokken.

De wijkverpleging verleende in geen der gevallen meer dan twee en een half uur zorg per dag; in zes gevallen kon zelfs met éên uur of minder worden volstaan. Dit houdt in dat de patiënten zich voor de wijkverpleging niet onderscheiden van reguliere eerstelijnspatiënten. Ook de huisartsen besteedden naar eigen zeggen aan de projectpatiènten, op één uitzondering na, niet meer tijd en zorg dan aan veel andere patiënten uit hun bestand. Wel werd meer tijd gevraagd voor overleg en coördinatie. Qua hulpinzet van de gezinszorg waren er wél belangrijke verschillen. Het gemiddeld aantal bij de projectpatiënten geïndiceerde uren bedroeg circa achttien uur per week. Normaal bedraagt de hulpinzet van de gezinszorg gemiddeld circa negen uur per week.

Hulpverleners waren van mening dat in vrijwel alle gevallen het zwaartepunt van de zorgbehoefte lag in de begeleidende en verzorgende sfeer. Bij dit alles moet worden bedacht, dat in tien van de elf cases verpleeghuisdagbehandeling gedurende drie dagen per week in het zorgplan was opgenomen. Op deze dagen behoefden gezinsverzorging en wijkverpleging niet of nauwelijks in actie te komen. Begin 1992 waren de tien thuiswonende patiênten nog alle tien in dagbehandeling. In enkele gevallen werd overwogen de frequentie met een dag te verminderen. De directe beschikbaarheid van verpleeghuisdagbehandeling voor deze patiènten is in dubbel opzicht van groot belang. Enerzijds kan dan zonder uitstel begonnen worden met de reactivering. Een direct begin van de reactivering is juist voor CVA-patiënten van eminent belang. Anderzijds is het als bijkomend effect hierdoor mogelijk het beroep dat moet worden gedaan op de thuiszorgbieders binnen redelijke grenzen te houden. 
itbehandelde ziekenhuispatiënt die wegens ziekenhuis blijft liggen, is bij uitstek een tionele denken in "lijnen" geen oplossingen Deze patiënten vormen in feite een nieuwe at meer dan noodzakelijk is.

al is op basis van ervaringen in elf proefcases derstelling dat thuiszorg, indien gecombiindeling, een oplossing kan bieden voor deze Igroep.

iszorg voor deze patiënten, waarnaar in het yoral te liggen in de begeleidende en verzorxrd door de gezinsverzorging. Qua medische fte weken de projectpatiẻnten nauwelijks af i.

$\mathrm{n}$ van mantelzorg maakt de in het project iit het ziekenhuis nagenoeg onmogelijk. Er daan worden over de mate waarin deze vorm keerde-plaatsprobleem kan helpen oplossen. in gang gezet.

voor thuiszorg in deze situatie met enig optiurde is, dat men erin slaagt een vast ontmoeamurale hulpverleners te creëren. Deze noodHeken is dat intramurale zorgverleners geen nde zorgbehoefte van intramurale verkeerng van verpleeghuisdagbehandelingscapaciok in de eerste lijn zal zich een capaciteitsproa gezinszorg- als voornaamste leverancier van kent reeds thans een beperkte wachtlijstproe vorm van zorgverlening zal echter -vanwege c de wijkverpleging in capaciteitsproblemen en dat dit waarschijnlijk relatief goedkoop op te sopvolleperspectief niet in de kiem zal smoren. 
Project Integraal Regionaa!

\section{LITERATUUR}

1. Ministerie van Welzijn, Volksgezondheid en Cultuur. Thuiszorg in de jaren "90. Notitie over de toekomstige ontwikkeling en stimulering van de thuiszorg. "s Gravenhage 1991.

2. Ministerie van Welzijn, Volksgezondheid en Cultuur. Programma Zorgvernieuwings" projecten Thuiszorg. Rijswijk, 1989.

3. Ministerie van Welzijn, Volksgezondheid en Culltuur. Samen werken aan zorg op maat (overzicht van de projecten in het Programma Zorgvernieuwingsprojecten Thuiszorg). Rijkswijk 1991 .

4. Rijksuniversiteit Limburg. Over starten en volhouden; evaluatie Programma Zorgvernieuwingsprojecten Thuiszorg van WVC. Maastricht, 1991. 